\title{
AVALIAÇÃO DA RESISTÊNCIA ADESIVA E DO PADRÃO DE CONDICIONAMENTO DA DENTINA E DO ESMALTE APÓS A APLICAÇÃO DO ÁCIDO BÓRICO A 2\%
}

\section{LEONARDO CÉSAR COSTA}

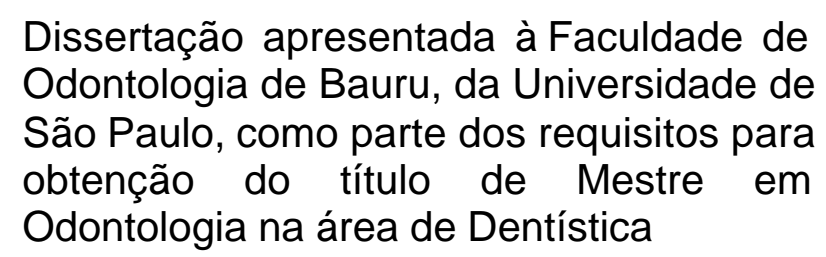

Edição Revisada

BAURU 


\title{
AVALIAÇÃO DA RESISTÊNCIA ADESIVA E DO PADRÃO DE CONDICIONAMENTO DA DENTINA E DO ESMALTE APÓS A APLICAÇÃO DO ÁCIDO BÓRICO A 2\%
}

\author{
LEONARDO CÉSAR COSTA
}

Dissertação apresentada à Faculdade de Odontologia de Bauru, da Universidade de São Paulo, como parte dos requisitos para obtenção do título de Mestre em Odontologia na área de Dentística

Orientador : Prof. Dr. José Carlos Pereira

Edição Revisada

BAURU 


\section{Costa, Leonardo César}

C823a Avaliação da resistência adesiva e do padräo de condicionamento da dentina e do esmalte após a aplicação do ácido bórico a $2 \%$

Leonardo César Costa - Bauru, 2003.

154p.: il; $30 \mathrm{~cm}$

Dissertação. (Mestrado) - Faculdade de Odontologia de Bauru.USP.

Orientador: Prof. José Carlos Pereira

Autorizo, exclusivamente para fins acadêmicos e científicos, a reprodução total ou parcial desta dissertação, por processos fotocopiadores e outros meios eletrônicos. Assinatura do autor:

Data:

sbseivą os̄oiba

Este estudo foi aprovado pelo Comitê de Ética em Pesquisa da Faculdade de Odontologia de Bauru - USP, em reunião de 26 de abril de 2001, como apresentado no anexo. 


\section{DADOS CURRICULARES}

\section{LEONARDO CÉSAR COSTA}

\begin{tabular}{|c|c|}
\hline 10 de março de 1972 & $\begin{array}{l}\text { Nascimento } \\
\text { Juiz de Fora - MG }\end{array}$ \\
\hline 1993-1997 & $\begin{array}{c}\text { Curso de Odontologia - Faculdade de Odontologia da } \\
\text { Universidade Federal de Juiz de Fora }\end{array}$ \\
\hline 1998-1999 & $\begin{array}{c}\text { Curso de Especialização em Dentística Restauradora pela } \\
\text { Faculdade de Odontologia de Bauru - USP }\end{array}$ \\
\hline 2000-2001 & $\begin{array}{l}\text { Professor do Departamento de Odontologia Restauradora da } \\
\text { Faculdade de Odontologia da Universidade Federal de Juiz } \\
\text { de Fora }\end{array}$ \\
\hline \multirow[t]{2}{*}{$2001-2003$} & $\begin{array}{l}\text { Curso de Pós-Graduação, em nível Mestrado,em Dentística } \\
\text { Restauradora pela Faculdade de Odontologia de Bauru - } \\
\text { USP }\end{array}$ \\
\hline & $\begin{array}{c}\text { ABO - Associação Brasileira de Odontologia } \\
\text { GBPD - Grupo Brasileiro de Professores de Dentística } \\
\text { SBPqO - Sociedade Brasileira de Pesquisa Odontológica }\end{array}$ \\
\hline
\end{tabular}


------------ Dedicatória 
Dedico este trabalho

A Deus, por me dar saúde, uma família maravilhosa, uma companheira especial e amigos com os quais, eu tenho certeza, posso contar.

Ao meu pai Edson, minha mãe Elisabeth, meu irmão Bernardo e minha irmã Fabiana por constituírem, juntamente comigo, uma família que é a grande responsável por todas as vitórias conquistadas até hoje em minha vida.

A Marcilene, minha namorada a quem tanto amo, companheira que caminhou ao meu lado durante o dia e me guiou durante a escuridão da noite. 
-------- Agradecimentos Especiais 
Ao Prof. Pereira

Durante esses dois anos, tive o privilégio de conviver com este ser humano ímpar. Profissionalmente, vou sequir o exemplo do Prof. Pereira na dedicação, rigorosidade e amor à Odontologia. Pessoalmente, o exemplo do homem José Carlos Pereira, que prima pela educação, cordialidade, honestidade e autenticidade.

Muito obrigado por tudo Professor e saiba que para mim o senhor é um verdadeiro MESTRE e um exemplo de um homen sábio, educado e de um caráter inestimável.

"Deus não escolhe os capacitados, capacita os escolhidos." Albert Einstein 
- Agradecimentos 
Aos meus amigos, Diego e Fábio, pela convivência durante esses dois anos, a que primou pela amizade e pelo companheirismo.

Aos meus amigos do curso de Mestrado, Bruno, Renato, Anderson, Anuradha, Flávia, Terezinha, Nádia, Natália, Eduardo e Luís.

Aos meus amigos do curso de Doutorado, Lawrence, Fernanda, Linda, Paulo, Celiane, Daniela, Juan e Juliano.

Aos professores do Departamento de Dentística da FOB/USP, José Mondelli, Rafael Mondelli, Ricardo Marins, Carlos Eduardo Francischone, Maria Tereza Atta, Aquira, Eduardo Batista, Mario Honorato e Maria Fidela, pelo exemplo diário de dedicação e amor à carreira docente.

Aos funcionários do Departamento de Dentística da FOB/USP, Nélson, Dito e Júnior, pela amizade e pela grande ajuda na realização deste trabalho. Às funcionárias Karem, Zilei, Rita, Heloísa, Beth e Ângela.

Às funcionárias da Pós-Graduação da FOB/USP, Ana e Cleuza, pela amizade e pela ajuda diária nas clínicas de pós-graduação.

Ao Aurélio, pelo auxílio na secretaria da pós-graduação.

À dona Heloísa pela contribuição durante a correção ortográfica. Às funcionárias da biblioteca da FOB/USP, Vera, Rita, Cibele, Valéria e Salvador, pela ajuda durante o levantamento bibliográfico. 
Ao Prof. Lauris, pela realização da análise estatística.

Ao Prof. Kitajima e aos pós-graduandos Francisco e Paulo, integrantes do núcleo de microscopia eletrônica da ESALQ/ Piracicaba, pelo auxílio durante a obtenção das imagens microscópicas contidas neste trabalho.

Ao Edimauro, pelo auxílio durante a preparação dos espécimes para o estudo de microscopia eletrônica.

Aos funcionários da Bioquímica, Ovídio e Telma, pelo preparo das soluções e pela ajuda durante a preparação dos espécimes para o estudo de microscopia eletrônica.

Aos professores da disciplina de Cirurgia Buco-Maxilo-Facial da Faculdade de Odontologia da Universidade Federal de Juiz de Fora, Prof. Renato Visconti e Prof ${ }^{\mathrm{a}}$. Neuza, pelo empenho na obtenção dos dentes para realização deste trabalho.

Ao CNPq, pelo auxílio financeiro durante a realização do trabalho. 


\section{SUMÁRIO}

RESUMO Xviii

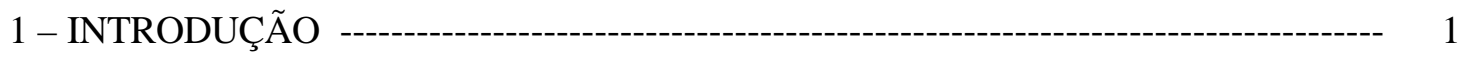

2 - REVISÃO DA LITERATURA -- 6

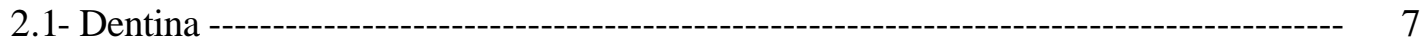

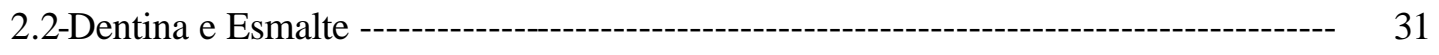

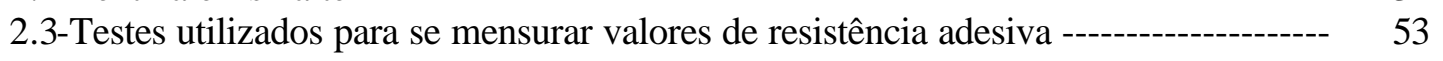

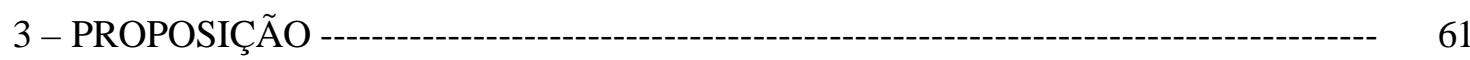

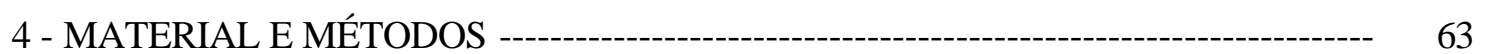

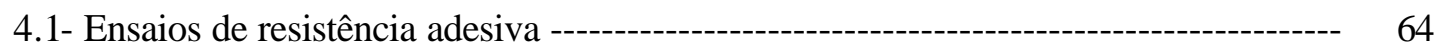

4.1-A- Obtenção dos dentes --- 64

4.1-B- Sistemas Restauradores ---------- 64

4.1-C- Preparo dos espécimes para os testes de resistência adesiva em dentina -------- 65

4.1-D- Preparo dos espécimes para os testes de resistência adesiva no esmalte -------- 69

4.1-E- Testes de Microtração ---

4.1-F- Análise estatística ----------- 73

4.2- Estudo do padrão de condicionamento superficial através de microscopia eletrônica de varredura (MEV) ------on 73

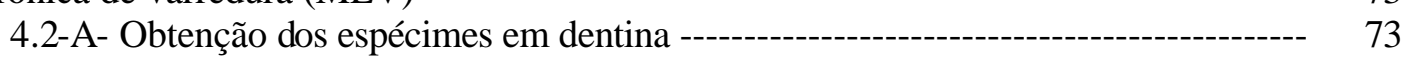

4.2-B- Obtenção dos espécimes em esmalte ---

4.2-C- Padronização da "smear layer" ---

4.2-D- Desidratação e fixação dos espécimes -------------------------- 76

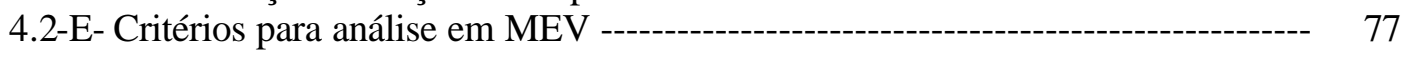

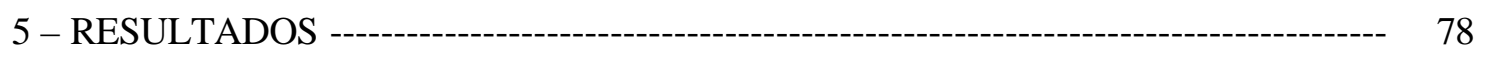

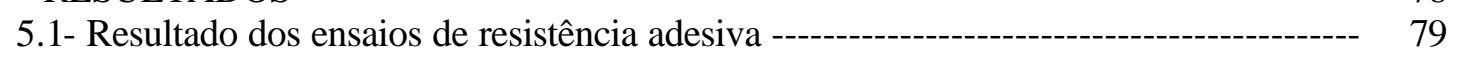

5.1-A- Resultado dos ensaios de resistência adesiva na dentina ----------------------- 79

5.1-B- Resultado dos ensaios de resistência adesiva no esmalte ------------------ 84

5.2- Resultado do padrão de condicionamento observado no microscópio eletrônico de varredura --------- 88

5.2-A- Resultado do padrão de condicionamento na dentina -------

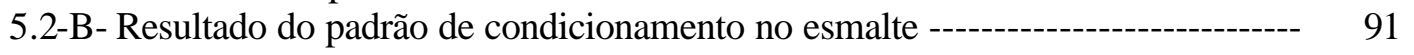

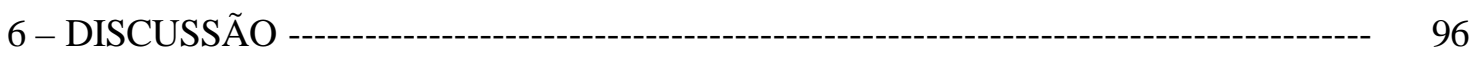

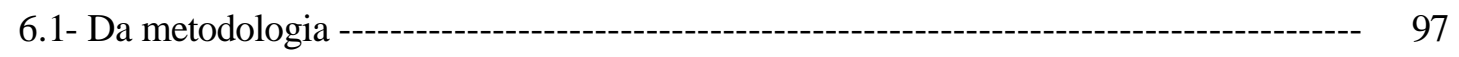

6.2- Dos resultados --- 104

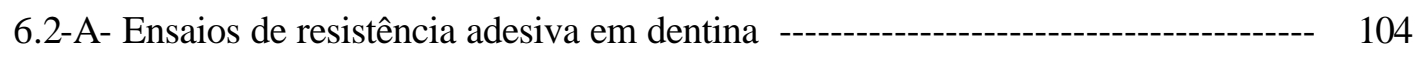

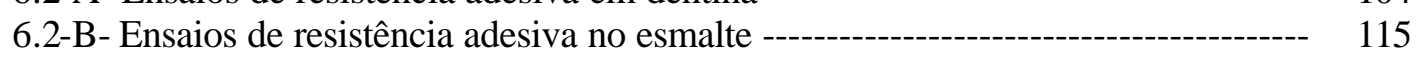

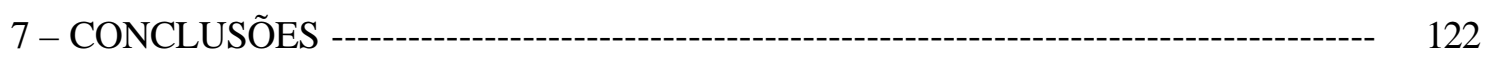

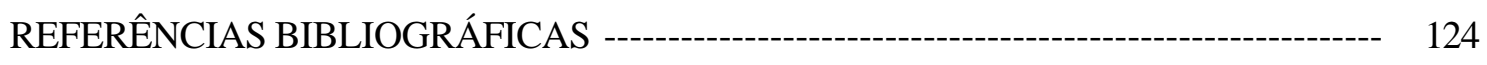

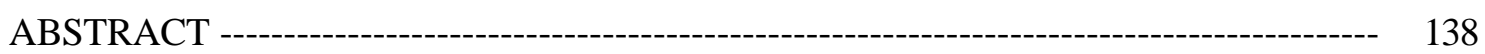

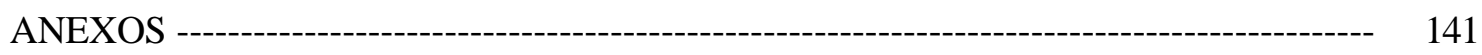




\section{LISTA DE FIGURAS}

FIGURA 1 - Procedimentos para a obtenção dos espécimes para os testes de microtração em dentina.
A) Corte perpendicular ao longo eixo do dente.
B) Aplicação do sistema adesivo.
C) Coroa reconstruída.
D,E) Vista oclusal dos dentes após os seccionamentos seriados.
F) Espécime composto por resina na porção superior, e dentina na inferior.
G) Estrangulamento na junção dente/material restaurador com ponta diamantada $\mathrm{n}^{\mathrm{0}} 1090$.
H) Espécime pronto para o teste de microtração.

FIGURA 2 - Procedimentos para a obtenção dos espécimes para os testes de microtração em esmalte.
A) Planificação das superfícies vestibular e lingual dos molares.
B) Padronização da "smear layer".
C) Aplicação do sistema adesivo.
D) Aplicação da resina composta pela técnica incremental.
E) Blocos de resina sobre as superfícies vestibular e lingual.
F) Cortes no sentido vestíbulo-lingual da coroa.
G) Corte no sentido transversal ao corte inicial.
H) Espécime composto por resina na porção superior, e esmalte na inferior.
I) Estrangulamento na junção dente/material restaurador com ponta diamantada $\mathrm{n}^{\mathrm{o}} 1090$.
J) Espécime pronto para o teste de microtração.

FIGURA 3 - Procedimentos para a realização dos testes de microtração.
A) Dispositivo (Mult-T, Bencor, USA) adaptado à máquina de ensaios universal (EMIC). 
B) Aplicação do adesivo à base de cianocrilato.

C) Espécime de dentina fixado no dispositivo.

D) Espécime de dentina fraturado após a realização do teste.

FIGURA 4 - Procedimentos para a obtenção dos espécimes para o estudo em microscopia eletrônica de varredura em dentina.
A) Corte perpendicular ao longo eixo do dente.
B) Segundo corte para obtenção do disco de dentina.
C) Disco de dentina.

FIGURA 5 - Procedimentos para a obtenção dos espécimes para o estudo em microscopia eletrônica de varredura em esmalte.
A) Planificação da superfície vestibular dos molares.
B) Desgaste com pontas diamantadas para obtenção do espécime quadrangular de esmalte.
C) Espécime de esmalte.

FIGURA 6 - A,B,C- Esquema demonstrativo da divisão dos discos de dentina em quadrantes com os seus respectivos tratamentos superficiais.

FIGURA 7 - Gráfico - Médias dos valores de resistência adesiva utilizando o sistema adesivo Single-Bond e a resina composta Z-250, com os diferentes tratamentos superficiais da dentina.

FIGURA 8 - Gráfico - Médias dos valores de resistência adesiva utilizando o sistema adesivo Prime\&Bond NT e a resina composta TPH, com os diferentes tratamentos superficiais da dentina.

FIGURA 9 - Fratura adesiva nos espécimes de dentina.

FIGURA 10 - Fratura mista nos espécimes de dentina.

FIGURA 11 - Fratura mista nos espécimes de dentina. 
FIGURA 12 - Gráfico - Médias dos valores de resistência adesiva utilizando o sistema adesivo Single-Bond e a resina composta Z-250 com os diferentes tratamentos superficiais do esmalte.

FIGURA 13 - Gráfico - Médias dos valores de resistência adesiva utilizando o sistema adesivo Prime\&Bond NT e a resina composta TPH com os diferentes tratamentos superficiais do esmalte.

FIGURA 14 - Fratura adesiva nos espécimes de esmalte.

FIGURA 15 - Fratura mista nos espécimes de esmalte.

FIGURA 16 - Fratura mista nos espécimes de esmalte.

FIGURA 17 - "Smear layer" padronizada na dentina.

FIGURA 18 -. Ácido fosfórico a 35\% por 15 segundos na dentina.

FIGURA 19 - Solução de ácido bórico a $2 \%$ por 30 segundos na dentina.

FIGURA 20 - Solução de ácido bórico a $2 \%$ por 1 minuto na dentina.

FIGURA 21 - Ácido bórico a 2\%, em forma de gel, por 30 segundos na dentina.

FIGURA 22 - Ácido bórico a 2\%, em forma de gel, por 1 minuto na dentina.

FIGURA 23 - Sistema adesivo Prime \& Bond NT na dentina.

FIGURA 24 - Sistema adesivo Single-Bond na dentina.

FIGURA 25 - "Smear layer" padronizada no esmalte.

FIGURA 26 - Ácido fosfórico a $35 \%$ por 30 segundos no esmalte.

FIGURA 27 - Solução de ácido bórico a $2 \%$ por 30 segundos no esmalte.

FIGURA 28 - Solução de ácido bórico por 1 minuto no esmalte.

FIGURA 29 - Ácido bórico a 2\%, em forma de gel, por 30 segundos no esmalte.

FIGURA 30 - Ácido bórico a 2\%, em forma de gel, por 1 minuto no esmalte.

FIGURA 31 - Sistema adesivo Prime \& Bond NT no esmalte.

FIGURA 32 - Sistema adesivo Single-Bond no esmalte. 


\section{LISTA DE TABELAS}

TABELA 1 - Dados estatísticos referentes aos grupos onde foram utilizados o sistema adesivo Single-Bond e a resina composta Z-250 em associação com os diferentes tratamentos superficiais da dentina.

TABELA 2 - Dados estatísticos referentes aos grupos onde foram utilizados o sistema adesivo Prime-Bond NT (PBNT) e a resina composta (TPH) em associação com os diferentes tratamentos superficiais da dentina.

TABELA 3 - Resultado dos tipos de fraturas para os grupos na dentina.

TABELA 4 - Dados estatísticos referentes aos grupos onde foram utilizados o sistema adesivo Single-bond e a resina composta Z-250 em associação com os diferentes tratamentos superficiais do esmalte.

TABELA 5 - Dados estatísticos referentes aos grupos onde foram utilizados o sistema adesivo Prime \& Bond NT (PBNT) e a resina composta (TPH) em associação com os diferentes tratamentos superficiais do esmalte.

TABELA 6 - Resultado dos tipos de fraturas para os grupos no esmalte.

TABELA 7 - Grupos de dentina com as respectivas áreas e valores de resistência adesiva para cada espécime.

TABELA 8 - Grupos de esmalte com as respectivas áreas e valores de resistência adesiva para cada espécime. 


\section{LISTA DE ABREVIATURAS E SÍMBOLOS}

\begin{tabular}{|c|c|}
\hline$\%$ & Porcentagem \\
\hline+ & Mais \\
\hline$<$ & Menor que ( para significância estatística) \\
\hline ì m & Micrômetro \\
\hline 4-META & 4-Metacriloxietil trimetilato anidro \\
\hline Ác. & Ácido \\
\hline ANOVA & Análise de variância \\
\hline BIS-GMA & Bisfenol glicidil metacrilato \\
\hline $\mathrm{cm} / \mathrm{min}$ & Centímetro por minuto \\
\hline D.P. & Desvio padrão \\
\hline EDTA & Ácido etileno diamino tetra-acético \\
\hline Fig. & Figura \\
\hline Figs. & Figuras \\
\hline HEMA & 2-hidroxi-etil-metacrilato \\
\hline HMDS & Hexametil-di-silasano \\
\hline $\mathrm{H}_{3} \mathrm{PO}_{4}$ & Ácido fosfórico \\
\hline $\mathrm{inch} / \mathrm{min}$ & Polegada por minuto \\
\hline $\mathrm{Kg}$ & Quilograma \\
\hline $\mathrm{Kg} / \mathrm{cm}^{2}$ & Quilograma por centímetro ao quadrado \\
\hline $\mathrm{Kg} / \mathrm{f}$ & Quilograma força \\
\hline $\mathrm{Kg} / \mathrm{cm}^{2}$ & Quilograma por centímetro ao quadrado \\
\hline $\mathrm{Kg} / \mathrm{mm}^{2}$ & Quilograma por milímetro ao quadrado \\
\hline $\mathrm{Kv}$ & Kilovolts \\
\hline $\mathrm{m}$ & Metro \\
\hline
\end{tabular}


Molar (notação química)

MEV Microscopia eletrônica de varredura

$\min \quad$ Minuto

mm Milímetro

$\mathrm{mm}^{2} \quad$ Milímetro ao quadrado

$\mathrm{mm} / \mathrm{min} \quad$ Milímetros por minuto

$\mathrm{MNm} \quad$ Meganewton por metro

$\mathrm{MN} / \mathrm{min} \quad$ Meganewton por minuto

MPa Mega pascal

mw/ $/ \mathrm{cm}^{2} \quad$ Miliwats por centímetro ao quadrado

n* Número de espécimes perdidos durante os testes de resistência adesiva.

nm Nanômetro

$\mathrm{n}^{\mathrm{o}} \quad$ Número

${ }^{\circ} \mathrm{C} \quad$ Graus Celsius

PBNT Prime \& Bond NT

PENTA Dipentaerythritol penta-acrilato monofosfato

$\mathrm{pH} \quad$ Potencial hidrogeniônico

Psi Libra por polegada ao quadrado

p/p Concentração peso por peso, indica a quantidade de soluto em $\mathrm{g}$

existente em $100 \mathrm{~g}$ de solução

s $\quad$ Segundo

SB Single-Bond

TEGDMA Tetraetilenoglicoldimetacrilato

v/v. Concentração volume por volume, indica o volume do soluto em $\mathrm{ml}$ existente em 100ml de solução 
Indica número de vezes

xvii 


\section{RESUMO}

O objetivo deste trabalho foi avaliar a resistência adesiva e o padrão de condicionamento do esmalte e da dentina após aplicação do ácido bórico a 2\%. Foram utilizados terceiros molares humanos, condicionados com o ácido fosfórico a 35\%, em forma de gel, e com diferentes formas de apresentações do ácido bórico a 2\%. Para o estudo do padrão de condicionamento, utilizaram-se discos de dentina e espécimes quadrangulares de esmalte que sofreram o condicionamento com as soluções de ácido fosfórico a $35 \%$ e diferentes formulações de ácido bórico a $2 \%$ utilizadas por diferentes tempos de aplicações. Após os condicionamentos, os espécimes foram preparados para observação no microscópio eletrônico de varredura. Para a avaliação da resistência adesiva do esmalte e da dentina, através de testes de microtração, foram utilizadas as soluções de ácido fosfórico a $35 \%$ e diferentes formulações de ácido bórico a $2 \%$ previamente à aplicação de dois sistemas adesivos (Single-Bond e Prime \& Bond NT) e de duas resinas composta (Z-250 e TPH). Após os procedimentos adesivos, os dentes sofreram seccionamentos seriados a fim de que fossem obtidos espécimes para os testes de resistência adesiva. Os valores adesivos foram submetidos ao teste de análise de variância (ANOVA) e ao teste de Tukey, para a verificação de possíveis diferenças estatísticas entre os grupos, e em ambos os testes foi adotado um nível de significância de $5 \%(\mathrm{p}<0,05 \%)$. Na dentina e no esmalte, a solução de ácido fosfórico a 35\% apresentou um maior poder desmineralizante comparado com as soluções de ácido bórico a 2\%. Com relação aos valores de resistência adesiva na dentina, quando se utilizaram as diferentes soluções ácidas com o sistema adesivo Single-Bond e a resina composta Z-250, o grupo condicionado com ácido fosfórico apresentou valores adesivos significantemente maiores que os grupos que sofreram condicionamento com as soluções de ácido bórico a 2\%. Porém, quando se utilizou o sistema adesivo Prime \& 
Bond NT e a resina composta TPH, os valores adesivos dos grupos que sofreram os diferentes condicionamentos ácidos não apresentaram diferenças estatísticas entre si. No esmalte, quando se utilizaram as diferentes soluções ácidas em associação com o sistema adesivo Single-Bond e a resina composta Z-250, e também com o sistema adesivo Prime \& Bond NT e a resina composta TPH, os grupos que sofreram o condicionamenmto com o ácido fosfórico a 35\% apresentaram valores adesivos significantementre maiores que os grupos que sofreram condicionamento com as soluções de ácido bórico a 2\%. Assim, pode-se concluir que o tratamento superficial da dentina e do esmalte com as soluções de ácido bórico a 2\% não forneceu substratos com características suficientes para proporcionar resistência adesiva semelhante à fornecida pelo ácido fosfórico a $35 \%$. 
1.INTRODUCÃO 


\section{1 - INTRODUÇÃO}

Com o advento da técnica de condicionamento ácido do esmalte, preconizada por BUONOCORE ${ }^{17}$ em 1955, e com o desenvolvimento das resinas compostas, em 1963, por BOWEN ${ }^{11}$, inicioutse uma nova era na odontologia restauradora. A partir da década de 70, as resinas compostas, após um período de descrédito em relação a sua utilização, em particular no segmento posterior da boca, tiveram suas formulações aprimoradas intensificando-se sua utilização na década de 80 com a introdução das resinas compostas fotopolimerizáveis. Em adição, a odontologia restauradora experimentou uma evolução significativa nestes últimos 20 anos com relação aos sistemas adesivos. Esses sistemas apresentam capacidade de união tanto ao esmalte quanto à dentina quando empregada a técnica de condicionamento ácido total, a qual foi inicialmente proposta por FUSAYAMA et al. ${ }^{35}$, em 1979. A partir desses trabalhos, os quais sugeriram o emprego da técnica de condicionamento ácido também para a dentina, iniciou-se uma nova era no desenvolvimento e na utilização dos sistemas adesivos. Existe a preocupação no meio odontológico em aceitar, indiscriminadamente, o uso da técnica de condicionamento ácido total, com relação, principalmente, ao potencial de agressão das soluções ácidas sobre o complexo dentinopulpar.

Várias formulações de ácidos em diferentes concentrações têm sido testadas para tratar a dentina e o esmalte, incluindo os ácidos poliacrílico, pirúvico, maleico, bórico, cítrico, nítrico e fosfórico $1,2,9,12,20,23,29,34,57,59,71,85,102,109$.

A tendência atual da odontologia adesiva é buscar agentes condicionadores cada vez menos agressivos, que causem o menor dano possível ao complexo dentinopulpar e 
que, ao mesmo tempo, propiciem preparação adequada dos substratos dentários para permitir interação com os sistemas adesivos.

Em 1984, FRANCISCHONE et al. ${ }^{34}$, observaram o efeito de vários agentes químicos sobre a dentina de 36 dentes extraídos, através de microscopia eletrônica de varredura. Foram utilizados os ácidos bórico a 2\%, cítrico a 50\%, fosfórico a 37\%, água destilada, Cavidry (Cyclohexatrione, ethinyl trichloride, dymethylcarbinol), EDTA a 15 $\%$, peróxido de hidrogênio, solução aquosa de hidróxido de cálcio, soro fisiológico, Tergentol (lauril-dietileno-glicol éter sulfonado de sódio), Tergidrox (lauril-sulfonado de sódio + hidróxido de cálcio) e Tubulicid (Dygluconato de chlorhexidine dodecil diaminoetil-glicina, fluoreto de sódio, água destilada). Observaram sobre a dentina condicionada com ácido bórico uma camada de partículas agregadas pouco espessa, possibilitando a visualização de alguns túbulos dentinários parcialmente ou totalmente obliterados por partículas dentinárias menores, as quais também se apresentavam dispersas sobre a superfície da amostra. Para os ácidos cítrico, fosfórico e EDTA, a camada de partículas agregadas foi removida completamente expondo, dessa forma, todos os túbulos dentinários e dissolvendo a dentina peritubular. Esse trabalho aventou, assim, a possibilidade de utilização do ácido bórico a $2 \%$ como agente condicionador, dentinário de efeito mais brando sobre a dentina preservando, ao mesmo tempo, a microestrutura dentinária e os "smear plugs".

Não houve, entretanto, continuidade nas pesquisas com essa formulação, provavelmente por causa da tendência de emprego de agentes condicionadores que expusessem completamente a superfície dentinária e seus túbulos para garantir a difusão 
dos monômeros resinosos na camada de dentina desmineralizada e formação da camada híbrida ${ }^{64}$.

Por outro lado, BRÄNNSTROM; JOHNSON ${ }^{12}$, em 1974, já preconizavam como característica de um agente condicionador ideal a capacidade de expor a superfície dentinária para completa interação com os materiais restauradores, mantendo os túbulos obstruídos pelos "smear plugs". Introduziram no mercado odontológico uma formulação à base de EDTA a 0,2\% e fluoreto de sódio (Tubulicid Red Label) como opção para limpeza e desinfecção cavitária. Os autores argumentavam sobre as vantagens de se manter obstruída a embocadura dos túbulos dentinários, minimizando a permeabilidade dentinária e protegendo o complexo dentinopulpar. Outros autores também estudaram as possíveis vantagens da utilização de ácidos mais fracos como condicionadores superficiais da dentina e do esmalte, no que diz respeito à minimização das agressões sobre a polpa sem prejuízo para a adesão dos materiais restauradores ${ }^{25}$, 29,43,90,107,111. Outros trabalhos recentes têm demonstrado, em polpas humanas, o resultado negativo da associação do condicionamento ácido total e aplicação de sistemas adesivos em cavidades profundas ${ }^{82,83}$.

Em 1998, PEREIRA; CASTRO ${ }^{81}$ reiniciaram os estudos com o ácido bórico como opção para o condicionamento da dentina. Os autores propuseram uma formulação de ácido bórico a $2 \%$ na forma de gel, que proporcionava uma superfície dentinária completamente livre de "smear layer", a exposição da trama de colágeno e, ao mesmo tempo, a preservação da dentina peritubular e dos "smear plugs". Para produzir esse efeito, o ácido bórico era aplicado por 30 segundos e 1 minuto. Os autores não observaram efeito condicionador significativo após aplicação por 15 segundos. 
Essas observações, entretanto, limitaram-se ao estudo das características superficiais da dentina condicionada em função do tempo de aplicação e comparativamente ao ácido fosfórico a 37\%, por 15 segundos. Assim, não há informações na literatura quanto ao efeito do ácido bórico a $2 \%$ na interação dos sistemas adesivos com o substrato dentinário e suas implicações na resistência adesiva dos sistemas restauradores resinosos. Não há, também, informações além daquelas apresentadas por FRANCISCHONE et al. ${ }^{34}$, em 1984, quanto aos padrões do esmalte condicionado com essa mesma formulação.

A suposta vantagem da utilização do ácido bórico seria a de se consequir uma resistência adesiva semelhante à conseguida após condicionamento com ácido fosfórico a 35\%, em uma superfície dentinária com a exposição das fibras colágenas e com a manutenção dos "smear plugs" no interior dos túbulos dentinários, ou seja, em uma superfície menos permeável. Assim, o presente trabalho visa, então, avaliar se o ácido bórico a $2 \%$ tem a capacidade de fornecer substratos dentinários e de esmalte com características suficientes para fornecer resistência adesiva semelhante à conseguida com o ácido fosfórico a $35 \%$. 
2. REVISÃO DA LITERATURA 


\section{2 - REVISÃO DE LITERATURA}

\section{1- Dentina}

A origem da chamada odontologia adesiva se deu em 1955, quando BUONOCORE $^{17}$ realizou um trabalho clássico objetivando encontrar um método que aumentasse a adesão dos materiais restauradores à superfície do esmalte. $\mathrm{O}$ autor, então, propôs a utilização de soluções ácidas no esmalte, antes da aplicação da resina, as quais promoveriam uma alteração física e química da superfície favorecendo a adesão. Assim, após resultados laboratoriais e clínicos, foi recomendado o uso de ácido fosfórico a 85\%, aplicado por um período de 30 segundos sobre a superfície do esmalte. Esta solução ácida objetivava desmineralizar o esmalte criando irregularidades as quais proporcionariam uma maior retenção para as resinas acrílicas disponíveis na época.

Após os resultados desse trabalho, BUONOCORE ${ }^{17}$ aventou a possibilidade de se tratar a superfície dentinária com soluções ácidas, objetivando também um aumento nos valores de resistência adesiva. Já em 1956, BUONOCORE; WILEMAN; BRUDEVOLD $^{18}$ realizaram um trabalho descrevendo a primeira tentativa de adesão à dentina, a qual foi condicionada com ácido e restaurada com resina acrílica. Nesse trabalho, os autores utilizaram dentes extraídos e, sobre a dentina exposta, aplicaram uma solução de ácido clorídrico a 7\% por 1 minuto. Posteriormente, aplicou-se uma resina em uma área circular de $5 \mathrm{~mm}$ de diâmetro. Os resultados demonstraram que os valores de resistência de união à tração duplicaram após o condicionamento ácido. Quando os espécimes foram armazenados em água, houve uma grande diminuição nos valores de resistência adesiva. Nas superfícies onde não foi realizado o condicionamento ácido, a resistência de união inicial foi de $28 \mathrm{Kg} / \mathrm{cm}^{2}$, sendo reduzida 
para $15 \mathrm{Kg} / \mathrm{cm}^{2}$ após três meses de armazenamento em água. Nas superfícies onde foi realizado o condicionamento ácido, a resistência de união inicial foi de $53 \mathrm{Kg} / \mathrm{cm}^{2}$, sendo reduzida para $28 \mathrm{Kg} / \mathrm{cm}^{2}$ após cinco meses de armazenamento em água. Após esses resultados, foi sugerido que a adesão era devida à possibilidade de combinação química entre um dos constituintes da resina e a matriz orgânica da dentina.

LEE,JR. et al. ${ }^{57}$, em 1973, observaram a ação dos ácidos fosfórico e cítrico sob a superficie da dentina. Foram utilizados molares e pré-molares hígidos extraídos e estocados em água destilada. Um disco de dentina foi obtido de cada dente e a superfície dentinária de cada disco foi condicionada com ácido cítrico a 50\% e com ácido fosfórico a $50 \%$ por períodos de 1, 2, e 5 minutos. Depois dos tratamentos, os discos foram metalizados para a observação do nível de descalcificação da superfície e dos túbulos dentinários ao microscópio eletrônico de varredura. Os autores observaram que o ácido cítrico é menos agressivo à dentina que o ácido fosfórico quando utilizado em tempos similares. Ficou evidenciado que quando $1 \mathrm{~mm}$ de dentina é exposto ao condicionamento com as soluções ácidas descritas acima, as mesmas só afetam a superfície, não penetrando no interior dos túbulos dentinários.

FUSAYAMA et al. ${ }^{35}$, em 1979, avaliaram a resistência adesiva ao esmalte, à dentina normal e à dentina afetada por cárie de sistemas adesivos com e sem o condicionamento ácido prévio das superfícies. Foram usados incisivos para o estudo no esmalte e molares para o estudo na dentina. As superfícies foram condicionadas com ácido fosfórico a 40\%, por 60 segundos, lavadas e secas. Após o condicionamento, foi aplicado o sistema adesivo Clearfil Bond System-F em associação com as resinas Clearfil, Adaptic, Concise e Palakav. A resistência adesiva às cargas de tração foi 
avaliada em um dispositivo desenvolvido pelo autor. Os resultados demonstraram que, após o condicionamento ácido das superfícies, a resistência adesiva ao esmalte aumentou de $26,3 \mathrm{Kg} / \mathrm{cm}^{2}$ para $111,5 \mathrm{Kg} / \mathrm{cm}^{2}$ e a da dentina aumentou de $16,8 \mathrm{Kg} / \mathrm{cm}^{2}$ para $62,3 \mathrm{Kg} / \mathrm{cm}^{2}$. Até a realização desse trabalho, somente se aceitava o condicionamento ácido do esmalte. O trabalho de FUSAYAMA ${ }^{35}$ demonstrou que a resistência de materiais adesivos à dentina poderia ser consideravelmente aumentada através de um condicionamento ácido da superfície.

NAKABAYASHI; KOJIMA; MASUHARA ${ }^{64}$, em um trabalho clássico na literatura, em 1982, avaliaram a adesão de uma solução 4-META ao esmalte e à dentina bovina e humana utilizando um cilindro de acrílico após o condicionamento com uma solução de ácido cítrico e cloreto férrico a 3\%. Os autores observaram, então, que os monômeros resinosos infiltravam-se pelas fibras colágenas, que foram expostas pelo condicionamento ácido, formando uma zona mista e ácido resistente. Esta zona era formada por dentina desmineralizada infiltrada por monômeros resinosos e foi denominada de camada híbrida, que promovia um aumento na adesão da resina composta à dentina. Assim, ficou demonstrado que a adesão ao substrato dentinário não se devia necessariamente à formação de "tags" no interior dos túbulos dentinários, mas, sim, a uma retenção micromecânica dos monômeros resinosos infiltrados nas fibras colágenas da dentina intertubular desmineralizada.

FRANCISCHONE et al. ${ }^{34}$, em 1984, avaliaram o efeito de alguns agentes de limpeza sobre a dentina através de microscopia eletrônica de varredura. Foram selecionados 36 dentes caninos humanos os quais foram limpos e armazenados em formalina até o momento de serem utilizados. Com o auxílio de uma ponta diamantada 
tronco-cônica de extremo arredondado, girando em alta velocidade, foi desgastada a face vestibular dos dentes eliminando-se a estrutura do esmalte em toda sua espessura. Os agentes de limpeza foram aplicados por meio de uma bolinha de algodão, friccionada por um período de 1 minuto. A seguir, a superfície tratada era seca com jatos de ar. As soluções ácidas receberam jatos de água por 3 a 5 segundos e, em seguida, secagem com jatos de ar. Os seguintes agentes de limpeza foram utilizados para o tratamento da dentina: ácido bórico a 2\%, ácido cítrico a 50\%, ácido fosfórico a $37 \%$, água destilada, cavidry, EDTA $15 \%$, peróxido de hidrogênio a 3\%, solução aquosa de hidróxido de cálcio, soro fisiológico, tergentol, tergidrox e tubulicid. Os autores concluíram que o efeito de limpeza dos agentes estudados foi significante. Os agentes de limpeza estudados foram divididos em 3 grupos seguindo uma ordem decrescente de efetividade na limpeza dentinária. Os grupos foram os seguintes: ácido cítrico a 50\%, ácido fosfórico a 37\% e EDTA a 15\%; tubulicid, ácido bórico a $2 \%$ e cavidry, tergentol, água destilada, peróxido de hidrogênio a 3\%, soro fisiológico, tergidrox, solução aquosa de hidróxido de cálcio.

Com o intuito de se avaliar a resistência adesiva à dentina, após diferentes condicionamentos ácidos, SILVA E SOUZA ${ }^{98}$, em 1986, utilizaram 60 dentes humanos que foram desgastados com pontas diamantadas com o objetivo de se expor a dentina. Em seguida, aplicaram-se as soluções de ácido fosfórico a 37\% em forma líquida e em gel e uma solução experimental composta por 10 partes de ácido cítrico e três partes de cloreto férrico por 1 minuto sobre a dentina. Após o tratamento ácido, foi aplicado o sistema adesivo Scothbond em conjunto com o selante Silar e a resina composta Silar. Foram seis os grupos experimentais: grupo 1: Solução experimental / Scotchbond / Silar; grupo 2: Ácido fosfórico 37\% (gel) / Scotchbond / Silar; grupo 3: Ácido fosfórico 
37\% (líquido) / resina fluida Silar / Resina pasta Silar; grupo 4: Solução experimental / resina fluida Silar / Resina pasta Silar; grupo 5: Ácido fosfórico 37\% (líquido) / Scotchbond / Silar e grupo 6: Ácido fosfórico 37\% (líquido) / Resina pasta Silar. Os valores de resistência à remoção em $\mathrm{Kg} / \mathrm{cm}^{2}$ foram: grupo $1(8,36)$, grupo 2 (10,88), grupo $3(2,48)$, grupo $4(2,39)$, grupo $5(8,65)$ e grupo $6(2,08)$. O autor concluiu que o condicionamento da superfície com ácido em forma de gel criou melhores condições de retenção que a solução experimental e o ácido em forma de líquido. Porém, o fator mais importante para a retenção não foi o condicionador, mas, sim, o adesivo intermediário. Concluiu-se que o adesivo Scotchbond propiciou maior adesividade às resinas compostas, quando aplicado sobre a dentina condicionada, que o selante Silar.

PASHLEY; TAO $^{72}$, em 1988, estudaram a resistência adesiva à dentina avaliando diferentes profundidades dentinárias e tratamentos superficiais. Os autores utilizaram terceiros molares hígidos e não irrompidos armazenados em solução salina contendo $0,2 \%$ de azido de sódio a $4^{\circ} \mathrm{C}$. Os dentes foram fixados em cilindros de resina e seccionados perpendicularmente ao seu longo eixo, utilizando-se discos de diamante com o objetivo de se eliminar o esmalte e expor a superfície dentinária. Posteriormente, a "smear layer" foi criada na dentina utilizando-se lixas de carbeto de silício de granulação 320 para o grupo A e brocas cone-invertido n 37 para o grupo B. Cinco diferentes tratamentos superficiais foram aplicados sobre as "smear layers" de cada grupo: grupo 1: água por 1 minuto, grupo 2: tratamento com ultra-som por 1 hora, grupo 3: solução EDTA a $0,2 \%$ (pH 0,7) por 1 minuto, grupo 4: solução de ácido cítrico a 6\% por 1 minuto e grupo 5: ácido fosfórico a 37\% por 15 segundos. Depois da lavagem da superfície com água, por 15 segundos, e secagem com jatos de ar, por 5 segundos, foram aplicados o sistema adesivo Scotchbond (3M) e duas camadas da resina Silux 
(3M). A resistência adesiva às cargas de cisalhamento foram medidas na máquina de testes Instron e os valores submetidos ao teste estatístico de análise de variância a um critério com $5 \%$ de significância. Os resultados demonstraram que a "smear layer" criada com lixas apresentou valores de resistência estatisticamente maiores que as criadas com brocas. O grupo 1 apresentou os maiores valores de resistência adesiva (5.7 MNm). Os grupos 2 (4.2), 3 (3.4), 4 (1.7) e 5 (1.0) apresentaram uma significante redução na resistência adesiva.

WENDT,JUNIOR.; JEBELES; LEINFELDER ${ }^{120}$, em 1990, realizaram um estudo com o objetivo de se avaliar a resistência adesiva à dentina após a aplicação de diferentes soluções ácidas. Os autores utilizaram 200 molares que tiveram a superfície dentinária condicionada com dois tipos de soluções ácidas: EDTA 0,5M e uma solução de 1:1 de ácido poliacrílico e ácido maleico $25 \mathrm{wt} \%$ por 40 segundos. Após os tratamentos ácidos, aplicou-se o sistema adesivo Gluma e foi construído um bloco de resina composta sobre a superfície. Os dentes foram divididos em cinco sub-grupos de acordo com o tempo de estocagem em água. As resistências adesivas às cargas de cisalhamento foram mensuradas na máquina de testes Instron, que funcionou a uma velocidade de $0,5 \mathrm{~mm} /$ minuto. Os resultados demonstraram que os dentes condicionados com a solução de 1:1 de ácido poliacrílico e ácido maleico $25 \mathrm{wt} \%$ apresentaram os maiores valores de resistência adesiva $(4,69 ; 4,72 ; 6,10 ; 7,28$ e 9,36 MPa). Os dentes condicionados com EDTA 0,5M apresentaram valores inferiores de resistência adesiva $(2,79 ; 4,65 ; 4,10 ; 4,06$ e 6,33$)$. Os autores ainda avaliaram o padrão de condicionamento das soluções ácidas descritas acima e observaram que a solução de 1:1 de ácido poliacrílico e ácido maleico $25 \mathrm{wt} \%$ apresentou um maior poder de remoção da "smear 
layer". Os autores relacionaram os maiores valores de resistência adesiva com esta propriedade desmineralizante da solução de ácido poliacrílico e ácido maleico.

KANCA et al. ${ }^{52}$, em 1991, avaliaram a resistência adesiva à dentina usando o sistema Scotchbond Dual Cure com e sem o condicionamento com ácido fosfórico. Foram usados 20 dentes, montados em resina acrílica, os quais receberam um corte perpendicular ao seu longo eixo com o objetivo de se expor a superfície dentinária. Posteriormente, a dentina foi padronizada com lixas de granulação 320. Assim, os dentes foram divididos em dois grupos. No grupo 1, foi aplicada uma camada do adesivo Scotchbond Dual Cure, a qual foi polimerizada por 20 segundos. No grupo 2, foi aplicado o ácido fosfórico em gel por 20 segundos. Posteriormente, aplicaram-se uma solução de N(p-tolyl) glicina-glicidil metacrilato e anidrido pyromellico em 2 hydroxyethyl metacrilato e o sistema adesivo Scothbond 2. Após todos os procedimentos adesivos, foi aplicada a resina P-50. Em seguida, os dentes foram estocados por 48 horas a $37^{\circ} \mathrm{C}$. A resistência adesiva foi medida na máquina de testes Instron, que funcionou a uma velocidade de $0,05 \mathrm{~cm} / \mathrm{min}$. Os resultados demonstraram diferenças estatísticas entre os grupos. O grupo dois apresentou valores significantemente maiores (12,8 $\mathrm{MPa})$ que o grupo 1 (5,5 $\mathrm{MPa})$.

$\mathrm{KANCA}^{53}$, em 1992, avaliaram a resistência adesiva à dentina utilizando diferentes condicionamentos ácidos e umidades dentinárias. O autor utilizou 60 molares humanos que foram desgastados com lixas 320. Os dentes receberam três tipos de tratamentos; aplicação do primer, sistema adesivo (All Bond 2 - Bisco) e resina composta diretamente sobre a "smear layer", condicionamento com ácido fosfórico a $10 \%$ por 30 segundos antes da aplicação do primer e do sistema adesivo e 
condicionamento com ácido fosfórico a 32\%, por 20 segundos, antes da aplicação do primer e do sistema adesivo. Outra variável no trabalho foi a umidade da dentina: todos os tipos de tratamentos foram realizados em dentina úmida e seca. A resistência às cargas de cisalhamento foram medidas na máquina de ensaios Instron. Os melhores resultados foram obtidos em dentina úmida e após o condicionamento ácido da dentina (34,3 e 36,5 MPa). Os menores valores foram obtidos em dentina seca e na ausência de condicionamento ácido (11,7 MPa).

STRICKLAND et al. ${ }^{102}$, em 1992, avaliaram a resistência adesiva à dentina e ao esmalte do sistema adesivo Gluma Bonding System, utilizando um condicionamento prévio com ácido pirúvico a 10\%. Os autores utilizaram 44 molares humanos para os testes em dentina e 44 incisivos para os testes em esmalte. Para os testes em dentina, a superfície dentinária foi exposta e uma "smear layer" foi criada com a lixa de carbeto de silício de granulação 600. Três grupos foram criados. No grupo 1, o sistema adesivo Gluma foi aplicado seguindo as orientações do fabricante, ou seja, foi aplicado o agente de limpeza Gluma 2 Cleanser, que contém uma solução aquosa de EDTA a 0,5 M, por 30 segundos; em seguida foi aplicado o primer por 30 segundos e, posteriormente, o adesivo. No grupo 2, foi realizado um condicionamento com ácido pirúvico a 10\%, por 15 segundos, previamente à aplicação do primer e do adesivo e, no grupo 3, foi realizado um condicionamento com ácido pirúvico a 10\%, por 15 segundos, uma aplicação de uma solução de glicina a $10 \%$ e, em seguida, a aplicação do primer e do adesivo. No esmalte, o grupo 1 recebeu tratamento com Gluma 1 Etchant, por 30 segundos, seguido da aplicação do primer e do adesivo. No grupo 2, foi aplicada uma solução de ácido pirúvico a 10\%, contento $10 \%$ de glicina, por 60 segundos, antes da aplicação do primer e do adesivo. No grupo 3, foi aplicada uma solução de ácido 
pirúvico a $10 \%$, por 15 segundos, uma solução de glicina a $10 \%$, por 30 segundos, antes da aplicação do primer e do adesivo. Assim, as superfícies receberam incrementos da resina Lumifor. A resistência adesiva às cargas de cisalhamento foram medidas na máquina de testes Instron, que funcionou a uma velocidade de $0,5 \mathrm{~mm} /$ minuto. Os resultados de resistência na dentina demonstraram que o grupo 2 e o grupo 3 apresentaram respectivamente 14,7 e 12,8 $\mathrm{MPa}$ de média de resistência adesiva, não apresentando diferença estatística significante entre si, mas significantemente maiores que o grupo 1 (8,7 MPa). No esmalte, não houve diferença estatísticas entre os grupos. Os autores ainda recomendam o uso do ácido pirúvico a 10\%, contendo glicina a 10\%, para o condicionamento ácido da dentina e do esmalte.

Com o objetivo de se avaliar a resistência adesiva de diversos sistemas adesivos à dentina utilizando-se vários tratamentos da "smear layer", DAVIS et al. ${ }^{27}$, em 1992 coletaram cento e vinte dentes para o estudo. A superfície oclusal dos dentes foi cortada para se expor a dentina. Sobre a superfície dentinária foi criada uma "smear layer" com a broca $n^{0} 56$ utilizada em um instrumento de baixa rotação. Quatro sistemas adesivos foram utilizados: All-Bond, Mirage Bond, Prisma Universal Bond e Scotchbond. Três tratamentos superficiais foram realizados sobre a "smear layer"; grupo 1: aplicação dos primers e dos sistemas adesivos diretamente sobre a "smear layer", grupo 2: aplicação de uma solução de ácido poliacrílico a 40\%, por 60 segundos, antes da aplicação dos sistemas adesivos e grupo 3: aplicação de uma solução de ácido fosfórico a 10\%, por 15 segundos, antes da aplicação dos sistemas adesivos. Posteriormente, a superfície recebeu dois incrementos da resina P50. Os testes de resistência às cargas de cisalhamento foram realizados na máquina de testes Instron, que funcionou a uma velocidade de $0,01 \mathrm{~cm} /$ minuto. Os resultados dos valores de resistência adesiva 
demonstraram que não houve diferença estatística entre o grupo 1 (8,26 MPa) e o grupo $3(9,22 \mathrm{MPa})$. Porém, ambos os grupos apresentaram valores estatisticamente maiores que o grupo $2(3,47 \mathrm{MPa})$.

SWIFT,JUNIOR.; DENEHY; BECK ${ }^{104}$, em 1993, avaliaram a resistência adesiva de sistemas adesivos à dentina após diferentes condicionamentos ácidos. Para o estudo, os autores utilizaram 50 molares humanos que tiveram a superfície vestibular exposta e condicionada por 15 segundos pelas seguintes soluções ácidas: grupo 1: (ácido maleico a 10\%); grupo 2: (ácido fosfórico a 35\%); grupo 3: (ácido fosfórico a 32\%); grupo 4: (ácido fosfórico a 10\%) e grupo 5: (ácido fosfórico a 25\% com cristais de oxalato de alumínio). Após os tratamentos ácidos, foi realizada a lavagem das soluções com spray de ar/água, por 15 segundos, a aplicação do sistema adesivo Scotchbond Multi-Purpose e da resina composta Z-100. Em seguida, os dentes receberam 300 ciclos térmicos. As resistências às cargas de cisalhamento foram medidas na máquina de testes Instron, que funcionou a uma velocidade de 0,5mm/minuto. A média de resistência adesiva dos grupos condicionados com ácido maleico a $10 \%(17,3 \mathrm{MPa})$, ácido fosfórico a 35\% (17,2 MPa), ácido fosfórico a 32\% $(15,2 \mathrm{MPa})$ e ácido fosfórico a $10 \%(13,6 \mathrm{MPa})$ não apresentou diferença estatística entre si. Porém, o grupo condicionado com ácido fosfórico a 25\%, com cristais de oxalato de alumínio, apresentou uma média de resistência adesiva estatisticamente menor com relação aos grupos anteriores $(5,2 \mathrm{MPa})$. Os autores preconizam o condicionamento com ácido maleico a 10\%, ácido fosfórico a 35\%, ácido fosfórico a $32 \%$ e ácido fosfórico a 10\%, previamente à utilização do sistema adesivo Scotchbond Multi-Purpose. 
Com a intenção de se avaliar a influência da composição das soluções ácidas na resistência adesiva à dentina, $\mathrm{KANCA}^{54}$, em 1993, realizou um estudo utilizando 120 molares humanos hígidos. Os dentes foram embebidos em acrílico autopolimerizável e seccionados perpendicularmente ao seu longo eixo com o objetivo de se expor a superfície dentinária para os futuros e distintos tratamentos superficiais. Após o tratamento com lixas de carbureto de silício de granulação 320, os dentes foram divididos em 4 grupos. Três sistemas adesivos foram usados: Tenure (utilizado seguindo as orientações do fabricante), Tenure (utilizado conforme o método desenvolvido pelo autor) e All Bond 2. Três diferentes soluções ácidas foram utilizadas: gel de ácido fosfórico a 37\% contendo sílica (Caulk gel etchant), gel de ácido fosfórico e oxalato (Etch n' Seal) e o líquido de ácido fosfórico a 38\%. Os agentes condicionadores foram aplicados sobre a dentina, por 20 segundos, e lavados com jatos de ar e água por 5 segundos. Após a aplicação dos agentes adesivos e confecção de um bloco de resina de $4 \mathrm{~mm}$ de diâmetro sobre a dentina, a resistência adesiva às cargas de cisalhamento foi medida na máquina de testes Instron a uma velocidade de 5 $\mathrm{mm}$ /minuto. As menores médias de resistência adesiva foram obtidas com os agentes condicionadores contendo oxalato (3.8, 4.9 e 16,1 Mpa). As maiores médias foram obtidas com a solução de ácido fosfórico a 38\% (18,3, 28,3 e 36,1Mpa). Nos grupos onde se utilizou o gel condicionador contendo sílica, os valores das médias de resistência adesiva apresentaram valores intermediários (10,6, 16,5 e 37,1Mpa).

CHAPPELL et al. $^{24}$, em 1994, realizaram um estudo com o objetivo de se avaliar e entender de uma melhor maneira o processo de adesão à dentina. Os autores avaliaram a importância das anastomoses dos prolongamentos de resina nos canais laterais dos túbulos dentinários com relação à resistência adesiva à dentina. Foram 
utilizados terceiros molares humanos que tiveram as coroas seccionadas a aproximadamente $2 \mathrm{~mm}$ da polpa. A superfície de dentina foi lixada com lixas de granulação 320 utilizaram-se os sistemas adesivos All-Bond 2, C\&B Metabond, Scothbond Multipurpose, Tenure Solution e XR-Bond e a resina composta P-50. Após os procedimentos adesivos, os espécimes foram desminerizados e preparados para observação ao microscópio eletrônico de varredura. Os resultados demonstraram que todos os sistemas empregados no trabalho apresentaram uma alta formação de prolongamentos resinosos dentro dos túbulos dentinários, com exceção do sistema XRBond e All-Bond 2. O sistema adesivo Scothbond Multipurpose foi o que apresentou o maior poder de penetração nos canais laterais. Como conclusão do trabalho, os autores descreveram que a penetração do material resinoso no interior destes canais laterais contribui para a adesão do material à dentina.

GWINNETT $^{43}$, em 1994, avaliou a resistência adesiva à dentina associada a três diferentes condicionamentos ácidos. O autor ainda avaliou a contribuição da zona de dentina desmineralizada, rica em fibras colágenas, em relação à resistência adesiva. Foram utilizados 90 molares extraídos e estocados em solução de $0,5 \%$ de cloramina. Os dentes foram divididos em três grupos, de acordo com cada sistema adesivo e resina composta utilizada: grupo 1: All Bond 2 e Bisfil grupo 2: Optibond Dual Cure e XRV e grupo 3: Scotchbond Multi-Purpose e Z100. Foi realizado um corte perpendicular ao longo eixo de cada dente com o objetivo de se expor a superfície dentinária que, uma vez exposta, foi preparada com lixas de carbeto de silício de granulação 320. Todos os grupos foram submetidos a três diferentes agentes condicionadores (ácido maleico a 10\% por 15 segundos, ácido fosfórico a $10 \%$ por 20 segundos e ácido nítrico a $10 \%$ por 60 segundos). Após o condicionamento ácido, foi realizada a lavagem da superfície, 
secagem e aplicação dos sistemas adesivos e resinas compostas seguindo as orientações do fabricante. A resistência adesiva às cargas de cisalhamento foi testada na máquina de ensaios Instron, com uma velocidade de $5 \mathrm{~mm} /$ minuto. Os resultados de resistência adesiva demonstraram que não houve diferença estatística entre os grupos que sofreram os diferentes tratamentos ácidos. Os valores de resistência adesiva em MPa foram: tratamento com ácido maleico a 10\%: 25,66, 30,35 e 25,22; tratamento com ácido fosfórico a 10\%: 24,20, 30,62 e 30,11 e tratamento com ácido nítrico a 2\%: 25,99, 28,91 e 30,07. Em adição, o autor concluiu que o grau de desmineralização da dentina não parece ser um fator crítico em relação à resistência adesiva, principalmente quando se utiliza a técnica úmida.

Com o objetivo de se avaliar a espessura da camada híbrida e sua relação com a resistência adesiva decorrentes do tratamento dentinário com condicionadores possuindo diferentes valores de pH, FINGER; INOUE; ASMUSSEN ${ }^{33}$, em 1994, utilizaram dentes humanos estocados em solução de cloramina a $1 \%$. A dentina da região proximal de cada dente foi exposta pelo desgaste com lixas de carbeto de silício de granulação 240 e 600. A superfície dentinária foi condicionada com os condicionadores Gluma 2000-1 (solução aquosa de ácido oxálico, pH 1,25, contendo nitrato de alumínio e glicina), solução experimental (solução aquosa de ácido oxálico, pH 3,6, contendo nitrato de alumínio e glicina) e Gluma 2 cleanser (EDTA, pH 7,4). Após os condicionamentos dentinários, realizaram-se a lavagem e a secagem da superfície antes da aplicação dos sistemas adesivos e da resina composta (Pekafill), para formar um bloco cilíndrico de 3,5mm de diâmetro e $1 \mathrm{~mm}$ de altura. A resistência adesiva à carga de cisalhamento foi medida e os valores em $\mathrm{Kg} / \mathrm{f}$ foram transformados em MPa. Os resultados de resistência adesiva demonstraram que não houve diferença 
estatística significante com relação aos tratamentos dentinários quando se utilizou os três diferentes agentes condicionadores. Em relação à espessura da camada híbrida formada após os diferentes tratamentos da dentina, os autores verificaram uma interdependência entre esta espessura e a resistência adesiva e, ainda, que a espessura está relacionada com o grau de descalcificação da dentina associado com a habilidade de infiltração da resina nesta área.

MATOS et al. ${ }^{59}$, em 1995, realizaram um estudo com o objetivo de observar a ação de diversos agentes utilizados para limpeza da superfície dentinária. Foram utilizados 20 dentes humanos hígidos submetidos a cortes para obtenção de discos planos de dentina. Dez dentes foram desgastados com pontas diamantadas de $\mathrm{n}^{\mathrm{o}} 1090 \mathrm{e}$ o restante com brocas carbide de $n^{0} 700$. Posteriormente, foram realizados os seguintes tratamentos de superfície: ácido maleico a $10 \%$ por 15 segundos, ácido fosfórico a 32\% por 15 segundos, ácido fosfórico a $10 \%$ por 15 segundos, solução de lauril sulfato de sódio por 15 segundos, hipoclorito de sódio por 15 segundos, flúor neutro por 4 minutos, flúor fosfato acidulado $(1,23 \%)$ por 1 minuto, peróxido de hidrogênio e pasta de pedra-pomes e água. Os autores observaram que todas as substâncias utilizadas promoveram algum tipo de alteração na superfície da dentina. As substâncias não desmineralizantes promoveram alterações em maior ou menor grau, sem expor a abertura dos túbulos dentinários, enquanto as soluções desmineralizantes promoveram alterações dentinárias expondo a abertura dos túbulos dentinários.

AYAD; ROSENSTIE; FARAG², em 1996, avaliaram várias soluções de ácido láctico, em diferentes concentrações e tempos de aplicação, com relação ao padrão de condicionamento da dentina e do esmalte e com relação à associação com sistemas 
adesivos e suas respectivas resistências adesivas. Os autores utilizaram 78 terceiros molares humanos hígidos. Para o estudo do padrão de condicionamento ácido, através de microscopia eletrônica de varredura, foram utilizados 28 dentes que receberam os diferentes tratamentos ácidos. Para o estudo de resistência adesiva foram utilizados 50 dentes que tiveram a superfície dentinária exposta para os tratamentos ácidos. Na dentina, foram utilizadas as soluções de ácido láctico a 10\%, por 10, 30 e 60 segundos, ácido láctico a $20 \%$, por 10 e 30 segundos, ácido láctico a 30\%, por 10 e 30 segundos, ácido láctico a 50\%, por 10 segundos, ácido fosfórico a 10\%, por 15 segundos, ácido fosfórico a 32\%, por 15 segundos, ácido cítrico a 10\%, por 10 segundos, ácido poliacrílico a 25\%, por 10 segundos e o grupo controle que não recebeu condicionamento ácido. No esmalte, a superfície proximal foi lixada com lixas de granulação 600 e condicionada com os seguintes agentes condicionadores: grupo A: solução de ácido lático a 50\%, por 15 segundos e grupo B: ácido fosfórico a 32\%, por 15 segundos. Após os tratamentos ácidos, foram aplicados o sistema adesivo All-Bond 2 e a resina composta Charisma. Os dentes foram estocados em água destilada, por 2 horas, e submetidos a 600 ciclos térmicos. As resistências adesivas às cargas de cisalhamento foram medidas na máquina de testes Instron, que funcionou a uma velocidade de $0,5 \mathrm{~mm} /$ minuto. No esmalte, os resultados de resistência adesiva não apresentaram diferenças estatísticas significantes - grupo A: 17,5 MPa e grupo B: 18,9 MPa. Na dentina, as médias de resistência adesiva dos grupos onde se utilizaram as soluções de ácido láctico foram similares às medias do grupo que utilizou o ácido fosfórico a 10\%. Com relação ao padrão de condicionamento ácido, as soluções de ácido láctico proporcionaram vários graus de desmineralização tanto na dentina como no esmalte. A solução de ácido láctico a 20\%, aplicada por 10 segundos sobre a dentina, apresentou uma mínima desmineralização dentinária. A solução de ácido lático a 30\% 
não somente removeu a "smear layer" como também desmineralizou a dentina peri e intertubular.

PIOCH et al. $^{84}$, em 1998, estudaram a influência de diferentes tempos de condicionamento ácido da dentina e sua relação com a espessura da camada híbrida e a resistência adesiva. Foram utilizados 775 molares humanos hígidos estocados em etanol a $50 \%$ a uma temperatura de $8^{\circ} \mathrm{C}$. Para os testes de resistência adesiva foram utilizados 450 molares que, após a exposição da dentina e preparo da mesma com lixas abrasivas de carbeto de silício de granulação 500, por 15 segundos, receberam condicionamentos superficiais com ácido fosfórico por diferentes períodos. Grupo1: sem condicionamento ácido, gr upo 2: 15 segundos, grupo 3: 30 segundos, grupo 4: 60 segundos, grupo 5: 120 segundos e grupo 5: 180 segundos. Após os diferentes condicionamentos, foram aplicados diferentes sistemas adesivos para cada grupo e duas camadas de resina composta sobre a superfície. A resistência às cargas de tração foram mensuradas na máquina de testes Zwick 1120 a uma velocidade de $1 \mathrm{~mm} /$ minuto. Os resultados demonstraram que os maiores valores de resistência adesiva foram produzidos pelo condicionamento ácido por 15 segundos $(7,5 ; 4,1 ; 10,2,4,8 ; 4,1$ e 6,2 MPa) seguidos pelos condicionamentos por 30 segundos $(6,9 ; 3,9 ; 6,2 ; 5,0 ; 3,6$ e 5,0), por 60 segundos $(7,6 ; 1,9 ; 3,6 ; 2,9 ; 2,5$ e 4,2), por 120 segundos $(5,8 ; 2,0 ; 2,3 ; 2,0 ; 2,4$ e 3,0$)$, por 180 segundos $(1,6 ; 3,1 ; 2,2 ; 1,0 ; 1,5$ e 1,9$)$ e sem condicionamento ácido $(0,8 ; 2,3 ; 3,9 ; 0,7$; 1,6 e 1,9). Com relação às características da camada híbrida, os autores observaram que longos períodos de condicionamento ácido proporcionaram um aumento na espessura da mesma e que esse fenômeno não significou um aumento na resistência adesiva. 
PAUL et al. ${ }^{75}$, em 1999, avaliaram a resistência adesiva através de testes de microtração à dentina do sistema adesivo Single-Bond após diferentes tratamentos ácidos. Os autores avaliaram, ainda, a infiltração de íons de prata na camada híbrida. Nove terceiros molares humanos tiveram o esmalte oclusal desgastado e a superfície dentinária exposta e lixada com lixas abrasivas de granulação 240 e 600. Os dentes foram divididos em três grupos: grupo 1: (condicionamento com ácido fosfórico a 35\% por 15 segundos), grupo 2: (condicionamento com ácido fosfórico a 35\% por 30 segundos) e grupo 3: (condicionamento com ácido fosfórico a 35\% por 60 segundos). Após o condicionamento ácido, os dentes foram lavados com água e foram aplicados o sistema adesivo Single-Bond e a resina composta Z100 sobre a superfície dentinária. Assim, os dentes foram seccionados e desgastados com o objetivo de se obterem espécimes para os testes de microtração. Os resultados dos valores de resistência adesiva demostraram que os grupos não apresentaram diferenças estatísticas significantes, ou seja, o aumento no tempo de condicionamento não acarretou uma queda nos valores de resistência. Porém, com relação à infiltração marginal, o aumento no tempo de condicionamento promoveu um aumento na quantidade de íons de prata infiltrados na camada híbrida.

No intuito de se avaliar a resistência adesiva do sistema adesivo Prime \& Bond 2.1 à dentina e ao esmalte, com diferentes tratamentos superficiais dos substratos, BARKMEIER; HAMMESFAHR; LATTA ${ }^{6}$, em 1999, utilizaram 90 molares humanos para o estudo. No esmalte, os autores utilizaram uma camada de adesivo para um grupo e duas camadas de adesivo para o outro grupo. Na dentina, além das duas variáveis descritas para o esmalte, os autores avaliaram se o condicionamento ácido prévio com ácido fosfórico a $37 \%$ influenciaria nos valores de resistência adesiva. Tanto a 
superfície do esmalte como a da dentina exposta foram planificadas com lixas de carbeto de silício de granulação 600. No esmalte, foi realizado o condicionamento ácido com ácido fosfórico a $37 \%$ por 15 segundos e, posteriormente, a aplicação do sistema adesivo em uma ou duas camadas. Na dentina, um grupo sofreu o condicionamento com ácido fosfórico a 37\% por 15 segundos, previamente à aplicação do adesivo, e no outro grupo foi aplicado o sistema adesivo diretamente sobre a "smear layer" criada. Após a aplicação dos adesivos, as superfícies receberam incrementos da resina composta Prisma TPH Spectrum. Assim, os dentes foram estocados em água deionizada por 24 horas a $37^{\circ} \mathrm{C}$. Em seguida, os dentes foram submetidos a 640 ciclos térmicos de 1 minuto. As forças de resistência adesiva às cargas de cisalhamento foram medidas na máquina de testes Instron, que funcionou a uma velocidade de $5 \mathrm{~mm} /$ minuto. Os resultados demonstraram que no esmalte não houve diferenças estatísticas entre os grupos $(29,8 ; 29,3$ e 29,2 MPa). Na dentina, também não se observou diferença estatística entre o grupo que recebeu o condicionamento ácido prévio (20,9; 20,0 e 18,6 MPa) e o grupo que não recebeu (21,3; 21,2 e 18,6 MPa).

CORDEIRO; VILELLA; NETTO ${ }^{25}$, em 1999, avaliaram a resistência adesiva dos sistemas adesivos Clearfil Liner Bond 2 e Prime \& Bond 2.1 com e sem condicionamento ácido prévio. Os autores utilizaram 27 dentes terceiros molares os quais foram divididos em três grupos. Foi realizado um corte perpendicular ao longo eixo do dente de modo que se deixassem 1,5 a $2 \mathrm{~mm}$ de dentina remanescente. No grupo A, foi realizado a aplicação do primer e do sistema adesivo Clearfil Liner Bond 2 diretamente sobre a "smear layer". No grupo B, foi realizado o condicionamento com ácido fosfórico a 37\%, por 15 segundos, antes da aplicação do primer e do sistema adesivo Clearfil Liner Bond 2. No grupo C, foi realizado o condicionamento com ácido 
fosfórico a 37\%, por 15 segundos, antes da aplicação do sistema adesivo Prime \& Bond 2.1. Logo após a aplicação dos sistemas adesivos, as amostras foram preenchidas com resina composta Z-100 com o auxílio de um sistema matriz. Os dentes foram armazenados por sete dias e, então, submetidos à ciclagem térmica em 500 ciclos, com temperaturas de 5 e $55^{\circ} \mathrm{C}$. Em seguida, foram executados cortes de $1 \mathrm{~mm}$ de espessura no sentido mésio-distal de cada dente através de uma máquina EXTEC, para que fossem obtidos 3 corpos de prova. Estes foram submetidos ao teste de microtração na máquina de testes EMIC. Os resultados de resistência adesiva para cada grupo foram: grupo A: 29,85 MPa, grupo B: 40,19 Mpa e grupo C: 21,75 MPa. O grupo B apresentou valores estatisticamente superiores aos grupos A e C.

Com o propósito de se estudar o efeito de vários tratamentos ácidos na dentina, BENDERLI; YUCEL ${ }^{9}$, em 1999, utilizaram terceiros molares extraídos e estocados a $4^{\circ} \mathrm{C}$. Os dentes foram seccionados perpendicularmente em seu longo eixo com o objetivo de se obter um disco de dentina de $3 \mathrm{~mm}$ de espessura. Esse disco foi dividido em quatro partes iguais e cada parte forneceu um cilindro de dentina possuindo $3 \mathrm{~mm}$ de altura e 5mm de diâmetro. Quatro soluções ácidas foram usadas sobre a superfície dentinária (ácido fosfórico a 37\%, ácido maleico a 10\%, Na-EDTA a 10\% e ácido cítrico/cloreto férrico 10/3\%) com dois diferentes períodos de tempo (15 segundos e 30 segundos). Posteriormente aos tratamentos ácidos, foi realizada a lavagem da superfície e aplicação dos sistemas adesivos e resinas compostas. A resistência às cargas de tração foram medidas na máquina de testes Instron 1115, onde foi utilizada uma velocidade de tração de $1 \mathrm{~mm} /$ minuto. Os resultados demonstraram que o tempo de aplicação de 60 segundos esteve associado a um aumento nos valores de resistência adesiva para as soluções de ácido maleico (14,9 MPa) e Na-EDTA $(6,9)$ e uma diminuição da 
resistência para as soluções de ácido fosfórico $(6,3)$ e ácido cítrico/cloreto férrico $(5,6)$. O tempo de 15 segundos esteve associado a um aumento nos valores de resistência para as soluções de ácido fosfórico (12,9) e ácido cítrico/cloreto férrico $(19,6)$ e uma diminuição da resistência para as soluções de ácido maleico $(9,0)$ e Na-EDTA $(6,9)$.

TATE; YOU; POWERS ${ }^{106}$, em 1999, avaliaram a influência do condicionamento ácido na resistência adesiva de compômeros em associação com vários primers ácidos. Cento e quarenta molares humanos foram extraídos e estocados em solução salina contendo $0,25 \%$ de azido de sódio. Os dentes tiveram as superfícies vestibular e palatina expostas para os futuros tratamentos superficiais. Sete diferentes compômeros com seus respectivos sistemas adesivos foram usados no estudo em associação com a presença ou não do condicionamento com ácido fosfórico a $37 \%$ por 15 segundos. Os sistemas adesivos utilizados foram: F2000, Single-Bond, Prime\&Bond 2.1, OSB, Sintac e STAE. Após o condicionamento ou não da dentina, realizaram-se a lavagem e secagem da superfície. Posteriormente, aplicavam-se os sistemas adesivos e os respectivos compômeros. A resistência às cargas de tração foram medidas na máquina de ensaios Instron, que funcionou a uma velocidade de $0,5 \mathrm{~mm} / \mathrm{minuto}$. Após o condicionamento ácido, a resistência adesiva aumentou na maioria dos sistemas adesivos utilizados. O sistema adesivo F2000 apresentou uma diminuição nos valores de resistência adesiva (13,3 MPa com condicionamento, e 16,1 sem condicionamento) e o sistema Sintac não apresentou diferença de resistência adesiva na presença ou não do condicionamento ácido (16,1 com condicionamento, e 15,6 sem condicionamento).

CASTRO $^{23}$, em 2000, avaliou em MEV o efeito de um ácido experimental (ácido bórico a 2\%) na superfície dentinária de dentes humanos extraídos, comparados 
com o ácido fosfórico a 37\%. Foram preparados discos de dentina de 1 a 1,2 mm de espessura os quais foram desgastados com lixas de granulação 600 para se obter uma "smear layer" regular. Cada disco teve metade de sua superfície oclusal tratada com as soluções descritas acima. Foram usadas as soluções em forma líquida e em forma de gel por tempos de 15 segundos, 30 segundos e 1 minuto. O autor observou que a solução de ácido fosfórico a 37\% aumentou progresivamente a desmineralização dentinária quando o tempo de condicionamento aumentou. A solução de ácido bórico a 2\% teve um pequeno efeito sobre a "smear layer" em 15 segundos de condicionamento. Nos tempos de 30 e 60 segundos, a desmineralização foi semelhante à conseguida com ácido fosfórico a $37 \%$ por 15 segundos, porém com a presença de "smear plugs" nos túbulos dentinários. A solução de ácido bórico em forma de gel apresentou um maior poder desmineralizante comparado com a solução líquida. Após o trabalho, o autor especula sobre a possibilidade da utilização da solução de ácido bórico a $2 \%$ como agente condicionador antes da aplicação de sistemas adesivos.

Com a finalidade de se avaliar a resistência adesiva à dentina, por ensaios de tração, empregando o sistema adesivo Scotchbond Multi-Purpose Plus e o compósito Z100 e a micromorfologia da dentina após o condicionamento com diferentes soluções ácidas, TEBECHRANI; MUENCH; JÚNIOR ${ }^{107}$, em 2000, utilizaram 56 molares humanos. Os dentes foram seccionados no sentido mésio-distal e diferentes tipos de ácidos (ácido fosfórico a 35\%, ácido maleico a 10\% e ácido fosfórico a 10\%) foram aplicados por 5 e 15 segundos. Foi utilizado um grupo controle isento de condicionamento ácido. Após o condicionamento com as soluções ácidas, foram aplicados o sistema adesivo Scothbond Multi-Purpose Plus e duas camadas de resina composta Z 100. Em seguida, os dentes foram imersos em água destilada a 37\% por 7 
dias. Os ensaios de tração foram realizados na máquina de ensaios universal Otto Wolpert-Werke. Os resultados demonstraram que o grupo controle apresentou valores significantemente menores comparados com os valores obtidos pelos grupos onde foi realizado algum tipo de tratamento ácido. Em média, o ácido fosfórico a 10\% aplicado pelo tempo de 15 segundos apresentou a maior resistência de união (12,18 MPa). Os ácidos fosfórico a $35 \%$ e maleico a $10 \%$ não apresentaram diferenças estatísticas significantes, o que, contudo, dependeram do tempo de condicionamento; com 5 segundos, o primeiro tendeu a apresentar menores valores e, com 15 segundos, maiores valores. Em média, o tempo de condicionamento de 15 segundos apresentou maior resistência de união do que o de 5 segundos. Os autores observaram, ainda, que o padrão de condicionamento ácido, observado através de microscopia eletrônica de varredura, pareceu não apresentar relação confiável com a resistência de união.

Com o propósito de se avaliar a resistência adesiva ao esmalte e à dentina com diferentes tratamentos superficiais dos mesmos, ROSA; PERDIGÃO ${ }^{92}$, em 2000, utilizaram 240 dentes bovinos que tiveram a superfície do esmalte e da dentina expostas e lixadas com lixas de carbeto de silício de granulação 400 e 600. Posteriormente, foram aplicados os sistemas adesivos no esmalte e na dentina de acordo com cada grupo. Grupo 1: Prompt L-Pop, por 15 segundos, grupo 2: Prime \& Bond NT, grupo 3: NRC (condicionador não lavável) + Prime \& Bond NT, grupo 4: Ácido fosfórico a 36\% por 15 segundos + Prime \& Bond NT, grupo 5: Prime \& Bond 2.1 e grupo 6: Ácido fosfórico a $36 \%$ por 15 segundos + Prime \& Bond 2.1. Após os diferentes tratamentos adesivos, tanto do esmalte como da dentina, os dentes foram divididos em duas categorias: o grupo que recebeu a resina composta TPH Spectrum e o grupo que recebeu os compômeros Dyract e Hytac. Assim, os espécimes foram estocados em água 
destilada a $37^{\circ} \mathrm{C}$, por 24 horas e, em seguida, submetidos a 500 ciclos térmicos. A resistência adesiva às cargas de cisalhamento foram medidas na máquina de testes Instron, que funcionou a uma velocidade de $5 \mathrm{~mm} /$ minuto. Para a resina composta, o condicionamento com ácido fosfórico resultou em altos valores de resistência adesiva no esmalte (23,4 e 24,2 MPa). Para o compônero, os mais altos valores de resistência adesiva foram conseguidos com a aplicação do ácido fosfórico e do sistema autocondicionante Prompt L- Pop (24,4, 23,0 e 24,7 MPa). Tratando a dentina com Prime \& Bond NT, sem o condicionamento ácido prévio, obtiveram-se altos valores de resistência adesiva tanto quando se utilizou a resina composta (18,2 MPa) como quando se utilizou o compômero (11,8 MPa).

JACOBSEN et al. ${ }^{51}$, em 2000, avaliaram e quantificaram a porcentagem de remoção de cálcio da dentina e a resistência adesiva à mesma após o tratamento com diferentes soluções de ácido fosfórico. Para os testes de resistência adesiva, foram utilizados 160 molares humanos hígidos que tiveram a superfície dentinária exposta através de um corte paralelo à superfície oclusal. Antes dos condicionamentos ácidos, a superfície foi desgastada com lixas de carbeto de silício de granulação 120, 320 e 600 . Posteriormente, a dentina foi condicionada com ácido fosfórico pelos tempos de 15, 30, 60 e 120 segundos. Após os diferentes tratamentos com soluções ácidas, a dentina foi lavada com água por 20 segundos, procedeu-se à secagem e foram aplicados o primer (Scothbond MP Primer) por 30 segundos e o sistema adesivo (Scotchbond MP). Duas camadas da resina Z-100 em encrementos de 1 a $2 \mathrm{~mm}$ foram aplicadas sobre a dentina. A resistência às cargas de cisalhamento foram medidas na máquina de testes Instron, que funcionou a uma velocidade de $0,5 \mathrm{~mm} /$ minuto. As médias de resistência foram: 22,3 MPa (15 segundos), 24,0 (30 segundos), 22,5 (60 segundos) e 21,7 (120 segundos). 
Observaram-se diferenças estatísticas somente entre os tempos de 30 segundos (maior valor) e 120 segundos (menor valor).

BLOMLOF, J. et al. ${ }^{10}$, em 2001, avaliaram a resistência adesiva de dois sistema adesivos à dentina utilizando diferentes condicionamentos ácidos. Os autores utilizaram vinte e um terceiros molares hígidos e estocados em água destilada. Vinte e nove superfícies de dentina foram preparadas desses vinte e um dentes. Uma das superfícies de dentina recebeu o tratamento com ácido fosfórico a $32 \%$ por 15 segundos e a superfície oposta recebeu o tratamento com EDTA a $24 \%$ por três minutos. Após os tratamentos ácidos, foi realizada a lavagem das soluções por 30 segundos. Foi aplicado o sistema adesivo All-Bond 2 e o sistema adesivo Prime \& Bond NT, de acordo com as orientações dos fabricantes, nas superfícies condicionadas. Após os procedimentos adesivos, aplicou-se a resina composta Tetric Flow. A resistência adesiva às cargas de cisalhamento foram mensuradas na máquina de testes Alwetron TCT 50, que funcionou a uma velocidade de $1 \mathrm{~mm} /$ minuto. Os resultados demonstraram que os maiores valores de resistência adesiva foram obtidos nos espécimes condicionados com EDTA e receberam o sistema adesivo All-Bond 2 (13,1 MPa). Os espécimes condicionados com ácido fosfórico e receberam o sistema adesivo All-Bond 2 apresentaram 8,2 $\mathrm{MPa}$ de média de resistência adesiva. Quando se utilizou o sistema adesivo Prime \& Bond NT, o condicionamento ácido parece não ter influenciado nos valores de resistência adesiva. Os autores preconizam que os primers contendo nanofilamentos são menos sensíveis ao volume de fibras colágenas expostas pelo condicionamento ácido.

AGOSTINI; KAADEN; POWERS ${ }^{1}$, em 2001, avaliaram a resistência adesiva ao esmalte e à dentina do sistema adesivo Prime \& Bond NT e de 3 sistemas 
autocondicionantes (Prompt L-Pop, Clearfil SE Bond e Etch and Prime 3.0). Quarenta molares foram seccionados buco-lingualmente e embebidos em resina acrílica, deixando-se as superfícies vestibular e lingual expostas. As superfícies foram desgastadas com lixas de carbeto de silício de granulação 600. Os sistemas adesivos foram aplicados sobre as superfícies do esmalte e da dentina e, posteriormente, a resina composta Pertac II foi aplicada sobre os sistemas adesivos. A resistência adesiva às cargas de tração foram medidas na máquina de testes Instron, que funcionou a uma velocidade de $0,5 \mathrm{~mm} /$ minuto. Os resultados demonstraram que, no esmalte, o sistema adesivo Prime \& Bond NT apresentou valores significantemente maiores (25,9 MPa) que os demais sistemas adesivos - Prompt L-Pop (18,5 MPa), Clearfil SE Bond (18,7 MPa) e Etch and Prime 3.0 (19,3 MPa). Na dentina, o sistema adesivo Clearfil SE Bond apresentou valores significantemente maiores (39 MPa) que os demais sistemas adesivos - Prompt L-Pop (0,0 MPa), Prime \& Bond NT (12,5 MPa) e Etch and Prime $3.0(0,0 \mathrm{MPa})$.

\section{2 - Dentina e Esmalte.}

Como descrito anteriormente, o uso de soluções ácidas na Odontologia, com o objetivo de se aumentar a retenção de materiais resinosos à estrutura dentária, iniciourse em 1955 com o clássico rabalho de BUONOCORE ${ }^{17}$. No esmalte, várias foram as soluções ácidas avaliadas para que fossem testados o padrão de condicionamento e a resistência adesiva de sistemas adesivos obtidos após a utilização destas soluções.

Em 1974, RETIEF $^{87}$ realizou um estudo e avaliou a resistência adesiva ao esmalte utilizando vários tipos de condicionamentos ácidos. O autor utilizou as soluções 
de ácido fosfórico a 50\% por 1 minuto, ácido fosfórico a 50\% em adição a 7\% de óxido de zinco, por 1 minuto, e uma solução de ácido cítrico a 50\% por 2 minutos. Após o condicionamento ácido da superfície, uma formulação de resina epóxica foi aplicada sobre a mesma. A resistência de união às cargas de tração foram medidas na máquina de testes Instron que funcionou a uma velocidade de $0,05 \mathrm{~cm} /$ minuto. Quinze espécimes foram testados para cada solução ácida. O autor utilizou um grupo controle onde a superfície do esmalte não foi condicionada com soluções ácidas, apenas polida com lixas de granulação 600. Os maiores valores de resistência adesiva foram conseguidos após o condicionamento com a solução de ácido fosfórico a 50\% em adição a 7\% de óxido de zinco (12,9 MPa). No grupo controle, a resina epóxica não aderiu à superfície do esmalte, havendo falha na adesão durante a estocagem dos dentes em água antes da realização dos testes. O grupo que foi condicionado com ácido fosfórico a 50\%, por 1minuto, apresentou 9,4 MPa de média de resistência. Quando se utilizou uma solução de ácido cítrico a 50\%, por 2 minutos, a média foi de 4,9 $\mathrm{MPa}$. Os autores creditaram os maiores valores do grupo com a solução de ácido fosfórico a 50\% em adição a 7\% de óxido de zinco $(12,9 \mathrm{MPa})$ ao pequeno ângulo de contato $\left(4-5^{\circ}\right)$ da resina com a superfície do esmalte.

MUENCH ${ }^{62}$, em 1976, avaliou a resistência adesiva da resina Adaptic ao esmalte após a aplicação de uma solução ácida usando diferentes técnicas. Foram usados incisivos, caninos e pré-molares os quais tiveram a superfície vestibular condicionada com o ácido por 1 minuto através de uma forma passiva e uma forma ativa. Após a aplicação da solução ácida, foram realizadas a lavagem e a secagem da superfície, aplicação do selante e colocação da resina sobre o esmalte. Após 24 horas, foram feitos os ensaios de resistência. Os resultados de resistência adesiva 
demonstraram que a maneira como a solução ácida é aplicada não influencia nos valores de resistência adesiva.

BRANNSTROM; NORDENVALL; MALMGREN ${ }^{14}$, em 1978, avaliaram o padrão de condicionamento ácido do esmalte através de microscopia eletrônica de varredura após o tratamento com o ácido fosfórico em forma de gel e em forma líquida. Observaram que ambas as soluções apresentam um mesmo padrão de condicionamento. Os autores preconizam o uso da solução em forma de gel por esta apresentar vantagens como melhor controle sobre a aplicação da solução ácida quando é preciso condicionar vários dentes ao mesmo tempo e quando é necessário condicionar a superfície palatina e dentes parcialmente irrompidos

GOTTLIEB et al. $^{41}$, em 1980, avaliaram a resistência adesiva de sistemas adesivos ao esmalte empregando diferentes concentrações de ácido fosfórico (10, 20, 30, 40, 50, 60 e 70\% w/w\%). Setenta incisivos centrais humanos foram utilizados para o estudo. Os dentes tiveram as superfícies vestibulares lixadas com lixas de granulação 600 e, em seguida, foram aplicadas as soluções ácidas por 1 minuto. Após o condicionamento, realizaram-se a lavagem das soluções com água, por 15 segundos, e a aplicação do sistema restaurador Concise. A resistência adesiva às cargas de tração foram medidas na máquina de testes Instron, que funcionou a uma velocidade de 0,02 inch/min. Os resultados demonstraram que não houve diferença estatística significante entre os grupos que receberam o condicionamento com as soluções de ácido fosfórico nas concentrações de 10 a 60 w/w\% $(18,38 ; 15,11 ; 12,35 ; 16,38 ; 15,53$ e 10,82MN/m²). Quando se utilizou a solução de ácido fosfórico a 70\%, os valores de resistência adesiva foram estatisticamente menores $(3,91)$. 
Com o objetivo de avaliação da influência de depósitos formados durante o condicionamento ácido, do tempo de condicionamento e do período de imersão em água nos valores de resistência adesiva de resinas compostas ao esmalte, BEECH; JALALY ${ }^{8}$, em 1980, utilizaram dentes humanos que tiveram a superfície do esmalte condicionada com ácido fosfórico por 5, 15 e 60 segundos. Com relação ao tempo de condicionamento, os autores verificaram que não houve diferença estatística entre os grupos condicionados pelos diferentes tempos. Os autores observaram, ainda, que uma eficiente rinsagem do ácido deve ser executada para que nenhum produto da reação do ácido com o dente impeça uma boa adesão ao esmalte.

Em 1982, BRANNSTROM; MALMGREN; NORDENVALL ${ }^{13}$ compararam o efeito da aplicação do gel de ácido fosfórico e da solução do mesmo ácido no esmalte. Compararam, ainda, o padrão de condicionamento do esmalte após a aplicação do ácido fosfórico em forma de gel por 15 e 60 segundos. Os autores utilizaram pré-molares que tiveram a superfície do esmalte condicionada com as soluções descritas acima. Os autores observaram que não houve diferença com relação ao padrão de condicionamento nas superfícies condicionadas com o gel de ácido fosfórico e da solução do mesmo ácido no esmalte. Com relação ao tempo, observaram que o condicionamento por 15 segundos fornece um padrão mais uniforme e uma superfície com melhores características retentivas, comparado à superfície que recebeu o tratamento por 60 segundos. Os autores preconizam que o condicionamento do esmalte com o ácido fosfórico pode ser realizado por 15 segundos sem nenhuma desvantagem clínica. 
WALKER; VANN,Jr. ${ }^{116}$, em 1984, avaliaram o padrão de condicionamento do esmalte, a formação e a penetração de "tags" de resina no interior do esmalte condicionado e a resistência adesiva de sistemas adesivos após o condicionamento com o ácido fosfórico a 33\% em solução e em forma de gel. Para o estudo da resistência adesiva, foram selecionados dentes decíduos anteriores que tiveram a superfície vestibular desgastada com lixas de granulação 600. Em seguida, foi aplicado o ácido fosfórico a 33\% em solução e em forma de gel, por 2 minutos. Após o condicionamento ácido, aplicaram-se o sistema adesivo Prisma Bond e a resina composta Prisma Fill. A resistência adesiva às cargas de cisalhamento foram mensuradas na máquina de testes Instron. Os resultados de resistência adesiva demonstraram que não houve diferença estatística entre os grupos, apesar de a solução de ácido fosfórico ter apresentado um melhor padrão de condicionamento e um maior número de "tags" de resina uniformemente distribuídos dentro do esmalte condicionado.

BARKMEIER; GWINNETT; SHAFFER ${ }^{4}$, em 1985, avaliaram a resistência adesiva ao esmalte após diferentes tempos de condicionamentos com ácido fosfórico. Foram utilizados 40 pré-molares humanos. As superfícies vestibulares dos dentes foram lixadas com lixas de granulação 240 e 600. Os dentes foram divididos em dois grupos. O grupo 1 foi condicionado com ácido fosfórico a 50\%, por 15 segundos, e o grupo 2 foi condicionado com ácido fosfórico a 50\% por 60 segundos. Após os tratamentos ácidos, foi realizada a lavagem das soluções por 20 segundos e foram fixados brackets ortodônticos com o sistema adesivo Caulk Self-cure e a resina composta Caulk SoloTach. As resistências adesivas às cargas de cisalhamento foram medidas na máquina de testes Instron, que funcionou a uma velocidade de $5 \mathrm{~mm} /$ minuto. Os resultados demonstraram que não houve diferença estatística entre o grupo 1 (1603 e 1796 psi) e o 
grupo 2 (1641 e 1788 psi). Os autores concluíram que os tempos de 15 e 60 segundos de condicionamento com ácido fosfórico podem ser indicados para os procedimentos adesivos em geral.

BARKMEIER; SHAFFER; GWINNETT ${ }^{7}$, em 1986, realizaram um trabalho com o objetivo de se avaliar a influência do tempo de condicionamento ácido na adesão e na morfologia do esmalte. Os autores utilizaram pré-molares humanos que tiveram a superfície do esmalte condicionada com as soluções de ácido fosfórico a 37\%. Os dentes foram divididos em dois grupos: grupo 1: condicionamento pelo tempo de 15 segundos e grupo 2: condicionamento pelo tempo de 60 segundos. Posteriormente ao condicionamento ácido, foram utilizados o sistema adesivo Prisma-Bond e a resina composta e Prisma-Fil. Os testes de resistência adesiva às cargas de cisalhamento foram realizados na máquina de testes Instron. Os resultados demonstraram que não houve diferença estatística significante entre as médias dos valores de resistência adesiva entre os diferentes grupos. Os autores observaram, ainda, que o padrão de condicionamento do esmalte observado no microscópio eletrônico de varredura foi similar entre os dois grupos.

RETIEF et al. ${ }^{91}$, em 1986, avaliaram a resistência adesiva ao esmalte após o condicionamento com diferentes soluções ácidas. Os autores utilizaram incisivos centrais humanos que tiveram a superfície desgastada com lixas de granulação 240 . Foram realizados os seguintes tratamentos superficiais: grupo 1: (não foi realizado condicionamento ácido), grupo 2: (foi realizado condicionamento com ácido pirúvico a 25\%), grupo 3: (foi realizado condicionamento com ácido fosfórico a 50\%) e grupo 4: (foi realizado condicionamento com ácido cítrico a 50\%). Posteriormente aos 
condicionamentos ácidos, foram aplicados a resina composta Concise e o selante de superfície Delton, com os respectivos sistemas adesivos. Foram realizados testes de tração na máquina de testes Instron a uma velocidade de 0,02 inch/minuto. Os resultados demonstraram que a solução de ácido pirúvico produziu valores significantemente maiores de resistência adesiva que os produzidos pelo ácido fosfórico $\left(19,1 ; 18,6\right.$ e 15,2; 13,5 MN.m ${ }^{-2}$ respectivamente). Porém, os valores de resistência obtidos com o ácido fosfórico foram significantemente maiores que os produzidos com o ácido cítrico $\left(15,2 ; 13,5\right.$ e 10,7;8,4 MN.m ${ }^{-2}$ respectivamente). Os autores ainda avaliaram a rugosidade da superfície após a aplicação de cada uma das soluções ácidas. Assim, eles observaram que as superfícies condicionadas com soluções de ácido pirúvico a $25 \%$ e ácido fosfórico a 50\% apresentaram uma maior rugosidade superficial do que a superfície condicionada com ácido cítrico a 50\%. Os autores relacionam os maiores valores de resistência adesiva a esse maior poder de criar irregularidades na superfície.

Com o propósito de se avaliar a resistência adesiva ao esmalte após o condicionamento com diferentes soluções ácidas, FARQUHAR ${ }^{29}$, em 1986, utilizou 96 pré-molares humanos que foram divididos em dois grupos, de acordo com o tratamento ácido realizado. No grupo A, foi realizada a aplicação do ácido poliacrílico por 30 segundos, na superfície do esmalte, a qual foi posteriormente lavada com jatos de água por 15 a 20 segundos. No grupo B, foi aplicado o ácido fosfórico a 43\%, por 90 segundos, seguido pela lavagem da superfície com jatos de água por 20 a 30 segundos. Após o condicionamento ácido, foi aplicado um selante (DELTON) sobre a superfície condicionada. Logo em seguida, foi adaptado um bracket como auxílio de um sistema adesivo. A resistência de união do bracket ao esmalte foi mensurada na máquina de 
testes Instron. Os resultados de resistência adesiva às cargas de cisalhamento para o grupo A foram de 6,3 e 7,7 $\mathrm{Kg}$ e para o grupo B foram de 22,9 e 20,6 Kg. A média de resistência ao cisalhamento do grupo condicionado com ácido fosfórico foi consideravelmente maior que a média do grupo condicionado com ácido poliacrílico.

BARKMEIER; GWINNETT; SHAFFER ${ }^{5}$, em 1987, avaliaram a resistência adesiva ao esmalte após diferentes tratamentos superficiais do mesmo. Foram utilizados 30 pré-molares humanos estocados em água destilada. $\mathrm{O}$ esmalte foi lixado com lixas de granulação 320 e 600. Em seguida, os dentes foram divididos em 4 grupos: grupo 1 (condicionamento com ácido fosfórico a 5\% por 5 segundos e aplicação do sistema adesivo one-step), grupo 2 (condicionamento com ácido fosfórico a 5\% por 60 segundos e aplicação do sistema adesivo one-step), grupo 3 (condicionamento com ácido fosfórico a 37\% por 60 segundos e aplicação do sistema adesivo pasta-pasta Concise) e grupo 4 (condicionamento com ácido fosfórico a 37\% por 60 segundos e aplicação do sistema adesivo one-step). Brackets ortodônticos foram fixados com a resina composta Concise sobre a superfície adesiva. As resistências às cargas de cisalhamento foram medidas na máquina de estes Instron. Os resultados demonstraram que não houve diferenças estatísticas significantes entre os grupos (grupo 1: 7,8 $\mathrm{MPa}$; grupo 2: 8,5; grupo 3: 9,5 e grupo 4: 8,5). Os autores ainda avaliaram o padrão de condicionamento de cada uma das soluções ácidas descritas acima e, embora esse padrão de condicionamento tenha sido diferente para as soluções descritas, os valores de resistência adesiva não apresentaram diferenças estatísticas.

O’ BRIEN III et al. ${ }^{70}$, também no ano de 1987 , avaliaram a resistência adesiva de sistemas adesivos ao esmalte após vários tipos de condicionamentos e após a 
contaminação por saliva. Foram usados caninos humanos hígidos que tiveram a superfície vestibular lixada e planificada com lixas de granulação 600. Os dentes foram, então, divididos em 4 grupos: grupo 1: (condicionamento com uma solução de ácido fosfórico a $37 \%$ por 60 segundos e lavagem por 15 segundos), grupo 2: (condicionamento com uma solução de ácido fosfórico a 37\% por 60 segundos e lavagem por 30 segundos), grupo 3: (condicionamento com uma solução, em forma de gel, de ácido fosfórico a 37\% por 60 segundos e lavagem por 15 segundos) e grupo 4: (condicionamento com uma solução, em forma de gel, de ácido fosfórico a 37\% por 60 segundos e lavagem por 30 segundos). Após os condicionamentos, os dentes receberam o sistema adesivo e a resina composta e foram montados na máquina de testes Instron, que realizou as forças de tração a uma velocidade de 0,02 inch.min ${ }^{-1}$. Os resultados demonstraram que não houve diferença estatística entre os grupos: grupo 1: (16,6 MPa), grupo 2: (16,2 MPa), grupo 3: (15,8 MPa) e grupo 4: (18,3 MPa).

Em 1988, BAHARAV et al. ${ }^{3}$ avaliaram o padrão de condicionamento da superfície do esmalte após a aplicação da solução aquosa e do gel de ácido fosfórico a 35\%. Os autores avaliaram, ainda, a influência da forma de aplicação da solução ácida (aplicação passiva ou ativa). Foram utilizados terceiros molares humanos hígidos que tiveram a superfície vestibular condicionada com os diferentes tratamentos ácidos. Tanto a solução líquida como o gel foram aplicados por 1 minuto ativamente e passivamente. Os resultados demonstraram que a forma ativa de aplicação produziu uma maior desmineralização do esmalte comparado com a forma passiva de aplicação. Quando a forma passiva de aplicaçào foi utilizada, o gel apresentou um maior poder de penetração no esmalte comparado com a solução líquida. 
Também no ano de 1988, BROWN $^{16}$ avaliou a capacidade de penetração da solução aquosa e do gel de ácido fosfórico a 37\% em fissuras oclusais. Os autores utilizaram molares humanos hígidos que tiveram as fissuras oclusais condicionadas com as soluções descritas acima, por 15 segundos. Os resultados demonstraram que o gel e a solução aquosa de ácido fosfórico apresentaram padrões similares de penetração nas fissuras da superfície oclusal. Assim, os autores preconizam o uso do gel por este apresentar vantagens como melhor controle durante a aplicação do ácido, o que reduz o perigo do ácido entrar em contato com os tecidos gengivais e dentes vizinhos.

SOUZA; UTRILLA; GABRIELLI ${ }^{101}$, em 1988, avaliaram a morfologia das projeções de diferentes resinas aplicadas no esmalte atacado por ácido fosfórico em forma de gel e solução. Foram utilizados incisivos e caninos permanentes que tiveram a superfície do esmalte condicionada com as soluções descritas acima por 1 minuto. Posteriormente, foram aplicadas as resinas fluidas e compostas sobre a superficie do esmalte. Os resultados demonstraram que, quando se utilizou a solução de ácido fosfórico, a penetração do material resinoso foi mais eficiente nos microporos do esmalte que se caracterizou pela formação de "tags" de maior profundidade.

FORTES; STEAGALL ${ }^{32}$, em 1988, pesquisaram a influência de diversas soluções de ácido fosfórico com concentrações diferentes, visando a identificar qual apresentaria melhores resultados, quando aplicadas no esmalte, referente ao teste de cisalhamento de resinas compostas. Os autores utilizaram 250 caninos e incisivos hígidos. Foram testadas soluções de ácido fosfórico em concentrações 16, 30, 37 e $50 \%$ $\mathrm{v} / \mathrm{v}$ e p/p.. As superfícies do esmalte dos dentes foram condicionadas com as soluções descritas acima por 1 minuto. Após o condicionamento, as superfícies foram lavadas e 
secas, e foram aplicados os sistemas adesivos e as resinas compostas (Silar, Simulate, Super C e Adaptic). Para a realização dos ensaios de resistência adesiva às cargas de cisalhamento, foi utilizada a máquina Riehle-Recorder Mondel. Os resultados demonstraram que o condicionamento com a solução a $37 \%$ v/v ofereceu a maior resistência ao cisalhamento $\left(214 \mathrm{Kgf} / \mathrm{cm}^{2}\right)$, sendo que, após a análise estatística, pode-se notar que estes valores foram estatisticamente superiores às resistências apresentadas quando se utilizaram as soluções $30 \% \mathrm{p} / \mathrm{p}\left(159 \mathrm{Kgf} / \mathrm{cm}^{2}\right), 16 \% \mathrm{v} / \mathrm{v}\left(156 \mathrm{Kgf} / \mathrm{cm}^{2}\right)$ e $16 \% \mathrm{p} / \mathrm{p}\left(155 \mathrm{Kgf} / \mathrm{cm}^{2}\right)$.

WANG; LU ${ }^{117}$, em 1991, utilizaram pré-molares de pacientes com idade de 9 a 16 anos com o intuito de se avaliar a resistência adesiva de brackets ortodônticos ao esmalte após o condicionamento do mesmo com ácido fosfórico a 37\% por 15, 30, 60, 90 e 120 segundos. Foram utilizados 50 dentes, divididos em grupos de acordo com o tempo de condicionamento ácido. Os resultados dos testes de resistência adesiva demonstraram que os grupos que foram condicionados pelos tempos de 15, 30, 60, e 90 segundos não apresentaram diferenças estatísticas significantes. Porém, o grupo que recebeu o condicionamento ácido por 120 segundos apresentou uma média de resistência adesiva inferior aos demais. Os autores concluem que o tempo de 15 segundos é o ideal para o condicionamento do esmalte com soluções de ácido fosfórico a $37 \%$.

GILPATRICK; ROSS; SIMONSEN ${ }^{40}$, em 1991, realizaram um estudo com o intuito de se observar a resistência adesiva ao esmalte através do condicionamento com ácido fosfórico a 37\% por 5, 10, 15 e 60 segundos. Os autores utilizaram 20 molares humanos que tiveram suas superfícies mesial e distal condicionadas com ácido fosfórico 
pelos tempos descritos acima. Após o condicionamento, foi aplicado o sistema adesivo Scotchbond 2 e incrementos de resina composta. A resistência às cargas de cisalhamento foram medidas na máquina de testes Instron. Os resultados de resistência adesiva demonstraram que não houve diferença estatística entre os grupos. Os valores foram, respectivamente, para cada grupo: 5 segundos (2635 Psi), 10 segundos (2366 Psi), 15 segundos (3028 Psi) e 60 segundos (2870 Psi). Apesar de os resultados terem indicado que a resistência adesiva não foi significantemente afetada pelas variações nos tempos de condicionamento ácido, os autores advertem que tempos muito curtos de condicionamento podem ser críticos com relação ao fenômeno da infiltração marginal.

GWINNETT; GARCIA-GODOY ${ }^{44}$, em 1992, realizaram um estudo com o objetivo de se avaliar a resistência adesiva ao esmalte decíduo após diversos tratamentos superficiais. Os autores utilizaram 50 incisivos hígidos. Os dentes foram divididos em 5 grupos: grupo 1: (camada superficial de esmalte tratada com ácido fosfórico a 37\%, em forma de gel, por 15 segundos), grupo 2: (camada não superficial de esmalte tratada com ácido fosfórico a 37\%, em forma de gel, por 15 segundos), grupo 3: (camada não superficial de esmalte tratada com ácido fosfórico a 10\%, em forma de gel, por 20 segundos), grupo 4: (camada superficial de esmalte tratada com ácido fosfórico a 10\%, em forma de gel, por 20 segundos e grupo 5: (camada superficial de esmalte tratada com ácido fosfórico a 37\%, em forma de gel, por 60 segundos). Antes dos condicionamentos com as soluções ácidas, a superfície vestibular dos dentes foi lixada com lixas de granulação 320. Após o condicionamento, a superfície foi lavada com spray de ar/água por 10 segundos. Em seguida, foram aplicados os sistemas adesivos e resinas compostas correspondentes (Prisma Universal e APH, All Bond e Biss Fill). As resistências adesivas às cargas de cisalhamento foram medidas na máquina de testes Instron a uma 
velocidade de $5 \mathrm{~mm} /$ minuto. Os resultados demonstraram que não houve diferença estatística entre os grupos: (grupo 1: 21,01 , grupo 2: 18,13, grupo 3: 19,79, grupo 4: 21,48 e grupo 5: 18,86 MPa).

SWIFT, Jr.; CLOE ${ }^{105}$, em 1993, avaliaram a resistência adesiva às cargas de cisalhamento de sistemas adesivos ao esmalte após o tratamento com diferentes soluções ácidas. Os autores utilizaram molares humanos extraídos, que foram divididos em 4 grupos, de acordo com o tratamento ácido realizado: grupo 1: (ácido fosfórico a $35 \%$ por 15 segundos), grupo 2: (ácido oxálico a 1,6\% + 2,6\% de nitrato de alumínio + 2,7\% de glicina por 30 segundos), grupo 3: (ácido maleico a 10\% por 15 segundos) e grupo 4: (ácido fosfórico a 10\% por 15 segundos). Após os tratamentos ácidos, foram aplicados os sistemas adesivos Gluma 4 Sealer e Scotchbond Multi-Purpose e a resina composta Prisma AP.H. Os espécimes foram estocados em água por 24 horas e receberam 300 ciclos térmicos antes de serem testados na máquina de testes Instron. Os resultados demonstraram que o grupo $1(24,5 \mathrm{MPa})$ apresentou valores de resistência adesiva significantemente superiores aos demais grupos. O grupo $2(13,2 \mathrm{MPa})$ e o grupo 3 (13,2 $\mathrm{MPa})$ não apresentaram diferenças estatísticas entre si, porém foram superiores ao grupo $4(6,3 \mathrm{MPa})$. Os autores concluem que o condicionamento com soluções de ácido fosfórico entre 35 e $40 \%$ devem ser considerados como primeira escolha para a realização de procedimentos adesivos no esmalte.

TRIOLO JUNIOR et al $^{109}$, em 1993, estudaram a resistência adesiva ao esmalte do sistema adesivo Scotchbond Multi-Purpose após o tratamento superficial com várias soluções ácidas e por diferentes períodos. Os autores utilizaram 90 molares humanos que tiveram as superfícies mesial e distal preparadas para a realização dos 
procedimentos adesivos. Foram utilizados os ácidos fosfórico a 35\%, maleico a $10 \%$ e uma solução de 1,6\% de ácido oxálico, 2,6 de nitrato de alumínio e 2,7\% de glicina por 15, 30 e 60 segundos. Após o condicionamento ácido, aplicaram-se o Scotchbond Multi-Purpose Primer em metade dos espécimes de cada grupo e o sistema adesivo Scotchbond Multi-Purpose e a resina composta Z-100 em todos os espécimes de todos os grupos. Posteriormente, os espécimes foram submetidos a 300 ciclos térmicos $\left(5^{\circ}-\right.$ $55^{\circ}$ ). A resistência adesiva às cargas de cisalhamento foram medidas na máquina de testes Instron. Os maiores valores de resistência adesiva foram conseguidos quando se utilizou o ácido fosfórico a 35\% por 15 segundos (21,8 MPa). Para o ácido fosfórico, o fator tempo não influenciou nos valores de resistência adesiva. Para o ácido maleico, os tempos de 15, 30 e 60 segundos apresentaram respectivamente os seguintes valores de resistência adesiva: 13,3; 15,7 e 19,0 MPa. A solução de 1,6\% de ácido oxálico, 2,6 de nitrato de alumínio e 2,7\% de glicina apresentou baixos valores de resistência para os tempos de 15 e 30 segundos (8,4 e 10,2 MPa), porém, quando se utilizou o tempo de 60 segundos, a média foi de 15,9 MPa. Os autores preconizaram o uso do ácido fosfórico a 35\%, por 15 segundos, e observaram que soluções ácidas mais fracas devem ser aplicadas no esmalte por um tempo relativamente maior.

HALLETT; GARCIA-GODOY; TROTTER ${ }^{46}$, em 1994, avaliaram o efeito do condicionamento com ácido maleico a $10 \%$ e com o ácido fosfórico a 37\%, na resistência adesiva ao esmalte, utilizando o sistema adesivo Scotchbond Multi-Purpose e a resina composta Z-100. Sessenta molares hígidos permanentes e vinte molares decíduos foram utilizados para o estudo. As superfícies mésio-bucais dos dentes foram planificadas com lixas de granulação 600. Assim, os dentes foram divididos em 4 grupos: grupo 1: (dente permanente condicionado com ácido maleico a $10 \%$ por 15 
segundos), grupo 2: (dente permanente condicionado com ácido maleico a $10 \%$ por 15 segundos), grupo 3: (dente permanente condicionado com ácido fosfórico a 37\% por 15 segundos) e grupo 4: (dente decíduo condicionado com ácido maleico a 10\% por 15 segundos). Após os condicionamentos, procederam-se a lavagem das soluções com água, por 5 segundos, à aplicação do sistema adesivo Scotchbond Multi-Purpose e da resina composta Z-100. Em seguida, os dentes receberam 1000 ciclos térmicos e a resistência às cargas de cisalhamento foram mensuradas na máquina de testes universal a uma velocidade de $0,5 \mathrm{~mm} /$ minuto. Os resultados demonstraram não haver diferenças estatísticas entre os grupos. Os autores concluíram que um condicionamento por 15 segundos, com qualquer tipo de ácido descrito acima, fornece adequada adesão ao esmalte.

WANG et al. ${ }^{118}$, em 1994, avaliaram a resistência adesiva de sistemas adesivos ao esmalte após a aplicação de várias concentrações de $\mathrm{H}_{3} \mathrm{PO}_{4}(2 \%, 5 \%, 10 \%, 20 \%$, $30 \%, 40 \%, 50 \%, 60 \%, 70 \%$ e $80 \%$ ). A superfície vestibular de pré- molares foi usada para a realização dos testes. Após a aplicação da solução ácida em suas diferentes concentrações, por 15 segundos, aplicaram-se o selante e a resina composta Concise. Os valores de resistência adesiva às cargas de tração foram medidos na máquina de testes Instrom. Os resultados demonstraram que os maiores valores de resistência adesiva foram obtidos com as concentrações entre 10 a $60 \%(0,68 ; 0,67 ; 0,69 ; 0,70 ; 0,69$ e $0,67 \mathrm{Kg} / \mathrm{mm}^{2}$ ). Valores intermediários de resistência adesiva foram obtidos nos espécimes condicionados com o $\mathrm{H}_{3} \mathrm{PO}_{4}$ nas concentrações de 5 e $70 \%(0,58$ e $0,53 \%)$. Os menores valores de resistência foram obtidos com as concentrações de 2 e $80 \%$ (0,46 e $0,45 \mathrm{Kg} / \mathrm{mm}^{2}$ ). Os autores acreditam que o condicionamento do esmalte com ácido fosfórico, em uma concentração de 10 a $30 \%$ por 15 segundos, fornece uma adequada 
resistência adesiva. O condicionamento com concentrações muito altas (70 e 80\%) e muito baixas (2 e 5\%) do ácido fosfórico resulta em uma queda da resistência adesiva.

Também, em 1994, HOSOYA ${ }^{48}$ verificou a influência do tempo de condicionamento ácido e da ciclagem térmica sobre a resistência adesiva ao esmalte. Os autores utilizaram 250 incisivos bovinos que tiveram a superfície condicionada com ácido fosfórico a 40\% por 0, 10, 20, 30 e 60 segundos. Foram utilizadas duas resinas compostas e dois sistema adesivos para os testes de resistência adesiva. Foi avaliada, ainda, a influência da ciclagem térmica nos valores de resistência adesiva. Os resultados demonstraram que a ciclagem térmica influenciou negativamente nos valores de resistência para um tipo de resina e positivamente para o outro. Com relação ao tempo de condicionamento, quando se utilizou a resina composta Silux, o tempo de 60 segundos foi o que apresentou os maiores valores de adesão. Porém, quando se utilizou a resina Photo Clearfil A, os tempos de 20 e 30 segundos foram os que apresentaram os maiores valores de adesão. Os autores observaram, também, que não houve uma correlação confiável entre o padrão de condicionamento do esmalte e os valores de resistência adesiva.

UNO; FINGER ${ }^{110}$, em 1995, avaliaram a resistência adesiva ao esmalte condicionado com várias soluções ácidas. Os autores utilizaram dentes humanos hígidos que foram condicionados por 30 segundos com uma solução de ácido maleico a 10\%, uma solução de ácido oxálico a 2,5\% e uma solução mista de ácido fosfórico/ $\mathrm{SiO}_{2} \mathrm{em}$ diferentes concentrações \%w/w $(5 / 5,10 / 5,20 / 5,35 / 5,20 / 0$ e 20/10). Após os tratamentos ácidos, realizaram-se a lavagem das soluções ácidas por 30 segundos e aplicação dos sistemas adesivos (Scotchbond Multi-Purpose Etchant, Gluma 2000-1, 
Gluma 3 Primer) e resinas compostas (Gluma 4 Sealer e Pekafill). Após a polimerização da resina composta, os dentes foram imersos em água por 24 horas, a $37^{\circ} \mathrm{C}$, antes de serem submetidos às cargas de cisalhamento. Os resultados demonstraram que não houve diferença estatística entre os grupos (solução de ácido male ico a 10\%: 17,6 MPa; solução de ácido oxálico a 2,5\%: 16,6 MPa, solução mista de ácido fosfórico/ $\mathrm{SiO}_{2}$ 5/5: 16,2 $\mathrm{MPa}, 10 / 5: 17,8 \mathrm{MPa}, 20 / 5: 18,5 \mathrm{MPa}, 35 / 5: 16,2 \mathrm{MPa}$, 20/0: 19,9 MPa e 20/10: 17,2 MPa).

REIFEIS; COCHRAN; MOORE ${ }^{86}$, em 1995, avaliaram a resistência adesiva ao esmalte após diferentes condicionamentos ácidos. Os autores utilizaram a superfície vestibular de incisivos bovinos e realizaram os seguintes tratamentos: grupo 1: (ácido fosfórico a $37 \%$ por 15 segundos), grupo 2: (condicionamento com ácido maleico e aplicação do sistema adesivo Scotchbond), grupo 3: (condicionamento com ácido cítrico e aplicação do sistema adesivo Liner Bond System), grupo 4: (condicionamento com ácido nítrico e aplicação do sistema adesivo Mirage Bond), grupo 5: (condicionamento com ácido oxálico e aplicação do sistema adesivo Gluma 2000), grupo 6: (aplicação do sistema adesivo Scotchbond), grupo 7: (aplicação do sistema adesivo Liner Bond System), grupo 8: (aplicação do sistema adesivo Mirage Bond) e grupo 9: (aplicação do sistema adesivo Gluma 2000). Após os tratamentos, foram aplicados os sistemas adesivos correspondentes e incrementos de resina composta Z-100. Em seguida, os dentes receberam 2500 ciclos térmicos e foram estocados durante 21 dias antes de serem submetidos aos testes de resistência ao cisalhamento na máquina de testes Instron. Os resultados de resistência adesiva demosntraram que os grupos 1,3 e 5 não apresentaram diferenças estatísticas entre si $(19,98 ; 22,52$ e 21,66 $\mathrm{MPa}$ respectivamente). $\mathrm{O}$ grupo 8 apresentou o menor valor $(8,81 \mathrm{MPa})$. Quando se 
utilizaram os sistemas adesivos Scotchbond e Gluma 2000, os resultados mostraram que o condicionamento ácido prévio não influenciou nos valores de resistência adesiva.

WASUNDHARA; HAZAREY ${ }^{119}$, em 1995, avaliaram a resistência adesiva ao esmalte de sistemas adesivos após o condicionamento com ácido fosfórico a 5\% e 37\%. Os autores utilizaram 50 pré-molares que foram divididos em dois grupos. O grupo A recebeu o condicionamento com ácido fosfórico a 5\%, por 60 segundos, e o grupo B recebeu o condicionamento com ácido fosfórico a 37\% por 60 segundos. Após os tratamentos ácidos, brackets ortodônticos foram aderidos à superfície do esmalte através da resina Concise. Posteriormente, os dentes foram estocados em água destilada a 37\% por 24 horas. A resistência de união foi medida na máquina Hounsefield. As médias de resistências às cargas de cisalhamento foram: grupo A: $1.07 \mathrm{Kg} / \mathrm{mm}^{2}$ e grupo $\mathrm{B}: 1.11$ $\mathrm{Kg} / \mathrm{mm}^{2}$. Não houve diferença estatística entre os grupos. Os autores preconizaram o uso do condicionamento com ácido fosfórico a 5\%, por 60 segundos, antes da aplicação de sistemas adesivos e ainda concluíram que, apesar de apresentar um mínimo desgaste da estrutura do esmalte, os valores de resistência de união, após o condicionamento nesta concentração, foram semelhantes aos obtidos com o mesmo ácido em concentração a $37 \%$.

Em 1995, HOLTAN et al. $^{47}$ avaliaram a resistência adesiva ao esmalte do sistema adesivo Scotchbond Multi-Purpose após diferentes condicionamentos ácidos. Foram usados 360 molares humanos que tiveram a sua superfície condicionada com os ácidos fosfórico a 35\%, fosfórico a 10\%, maleico a 10\% e uma solução aquosa de ácido oxálico a 1,6\% por 15, 30 e 60 segundos. Após os condicionamentos com as soluções ácidas, foram aplicados o sistema adesivo Scotchbond Multi-Purpose e dois 
incrementos da resina composta Silux Plus sobre a superfície tratada. Os espécimes foram submetidos a 1000 ciclos térmicos $\left(5^{\circ}-55^{\circ}\right)$. A resistência de união às cargas de cisalhamento foram medidas na máquina de testes Instron. Os resultados demonstraram que os maiores valores de resistência adesiva foram conseguidos com o ácido fosfórico a $10 \%(14,8 ; 19,3$ e $15,4 \mathrm{MPa})$ e $35 \%(15,3 ; 17,6$ e $18,4 \mathrm{MPa})$. Resultados intermediários foram relacionados com o ácido maleico a 10\% $(15,8 ; 14,5$ e 13,4 MPa) e os menores resultados foram relacionados à solução de ácido oxálico a 1,6\% $(4,9 ; 8,1$ e 8,4 MPa). Os autores observaram ainda que, quando o tempo de aplicação do ácido aumentou de 15 para 30 segundos, os valores de resistência adesiva aumentaram em três das quatro soluções ácidas. Quando o tempo de aplicação aumentou de 30 para 60 segundos, não foi observado um aumento nos valores de resistência adesiva. Os autores concluem que a solução de ácido oxálico a 1,6\% não parece ser eficaz para o tratamento do esmalte, antes da aplicação do sistema adesivo Scotchbond Multi-Purpose, e ainda indicam o condicionamento com ácido maléico a 10\%, por 15 segundos, para a finalidade descrita acima.

VAN DER VYEER; DE WET; JANSEN VAN RENSBURG ${ }^{11}$, em 1997, estudaram a resistência adesiva de resinas compostas ao esmalte utilizando diferentes condicionamentos ácidos. Os autores utilizaram 50 molares humanos que tiveram o esmalte planificado com a lixa de granulação 220. Os dentes receberam 5 diferentes tratamentos ácidos: grupo 1 (ácido fosfórico a 35\% por 30 segundos), grupo 2: (ácido fosfórico a 10\% por 20 segundos), grupo 3: (ácido maleico a 10\% por 15 segundos), grupo 4: (ácido fosfórico a 65\% por 30 segundos) e grupo 5: (10\% ácido cítrico / 3\% cloreto férrico por 30 segundos). Após os condicionamentos ácidos, foram aplicados o sistema adesivo (Scotchbond Multi-Purpose) e a resina composta Z-100 sobre a 
superfície. A resistência da interface adesiva às cargas de cisalhamento foram medidas na máquina de testes Instron. Os resultados demonstraram que o ácido maleico a 10\% (18,0 MPa), o ácido fosfórico a 10\% (18,9 MPa) e 10\% de ácido cítrico/ 3\% de cloreto férrico (15,6 MPa) demonstraram menores valores de resistência adesiva comparados com as soluções de ácido fosfórico a 35\% (23,9 MPa) e a 65\% (20,4 MPa). A solução contendo $10 \%$ de ácido cítrico/ 3\% de cloreto férrico apresentou baixos valores de resistência adesiva no esmalte sendo, assim, contra-indicado o seu uso clinicamente. Os autores recomendam o uso do ácido fosfórico nas concentrações de 35 e $65 \%$.

Em 1997, FAVA et al. ${ }^{30}$ avaliaram, através de microscopia eletrônica de varredura, a superfície do esmalte de molares após o condicionamento com o ácido fosfórico a 35\%. Os autores utilizaram 20 molares que tiveram a superfície condicionada com o ácido descrito anteriormente por tempos de 15, 30 e 45 segundos. As imagens microscópicas demosntraram diferentes padrões de condicionamentos ácidos. Após o condicionamento por 15 e 45 segundos, foi observada uma predominância do padrão tipo II segundo SILVERSTONE ${ }^{99}$. Os autores observaram, ainda, que um aumento no tempo de condicionamento provocava uma maior dissolução do esmalte interprismático.

$\mathrm{Na}$ intenção de se avaliar a resistência adesiva de uma resina composta ao esmalte, após diferentes condicionamentos ácidos, ORTEGA; SILVA E SOUZA Jr.; FRANCO $^{71}$, em 1997, utilizaram 45 incisivos centrais que foram divididos em três grupos de acordo com o tratamento superficial. $O$ primeiro grupo recebeu $o$ condicionamento com ácido fosfórico a $37 \%$ por 30 segundos; o segundo recebeu o condicionamento com ácido fosfórico a $10 \%$ por 30 segundos e o terceiro recebeu o 
condicinamento com ácido maléico a $10 \%$ por 30 segundos. Após os tratamentos ácidos, foram aplicados o sistema adesivo Scotchbond Multi-Uso e um cilindro de resina composta Z-100 sobre a superfície do esmalte. A resistência de união foi registrada na máquina de testes Kratos e a força aplicada a uma velocidade de 0,5mm/minuto. Foram preparados, também, espécimes para observação do padrão de condicionamento através de microscopia eletrônica de varredura. O grupo 1 (21,0 MPa) e 2 (19,6 MPa) não apresentaram diferenças estatísticas significantes. Porém, ambos os valores foram significantemente maiores que os do grupo $3(12,4 \mathrm{MPa})$. Assim, os autores contra-indicam o uso da solução de ácido maleico a $10 \%$ para o condicionamento do esmalte.

Com o objetivo de se avaliar o efeito do tempo de condicionamento nos valores de resistência adesiva de sistemas adesivos ao esmalte de molares, JOHNSTON et al. ${ }^{50}$, em 1998, realizaram um estudo utilizando o ácido fosfórico a 37\% por 15, 30 e 60 segundos. Após o condicionamento com as soluções ácidas descritas acima, foi aplicada na superfície vestibular dos molares a resina composta Concise. As resistências adesivas às cargas de cisalhamento foram medidas e os resultados demonstraram que o tempo de 15 segundos apresentou valores de união significantemente menores que os tempos de 30 e 60 segundos. Estes dois útimos não apresentaram valores adesivos com diferenças estatísticas significantes. Os autores salientam que o tempo de 30 segundos deva ser utilizado para o condicionamento do esmalte com a solução de ácido fosfórico a 37\%.

Para avaliar o efeito de três diferentes tratamentos superficiais do esmalte, na resistência adesiva de duas resinas compostas diferentes, PERDIGÃO et al. ${ }^{79}$, em 2000, utilizaram a superfície vestibular de cento e vinte dentes bovinos. A superfície foi lixada 
com lixas abrasivas de granulação 400 e 600 e, posteriormente, foram realizados os seguintes tratamentos: grupo 1: (foi aplicado o condicionamento com ácido fosfórico a $37 \%$, por 15 segundos, e o sistema adesivo Syntac), grupo 2: (foi aplicado o sistema adesivo Syntac sem condicionamento ácido prévio.), grupo 3: (foi aplicado o adesivo auto-condicionante Prompt L-Pop sem condicionamento ácido prévio). Após os tratamentos, foram aplicados incrementos de resina composta (Compoglass Flow, Tetric Flow, Compoglass F e Tetric Ceram). Antes de se testar a resistência adesiva na máquina de testes Instron, os dentes foram estocados em água destilada, por 24 horas, e receberam 500 ciclos térmicos. Os resultados demonstraram que os maiores valores de resistência adesiva foram obtidos com o grupo 1 (22,5; 15,0; 20,1 e 15,0 MPa). O grupo 3 apresentou valores intermediários (14,6; 13,1; 16,3 e 19,0 MPa). O grupo 2 apresentou os menores valores de resistência adesiva (13,7; 7,5; 18,4 e 8,7 MPa).

Em 2001, GARDNER; HOBSON ${ }^{39}$ avaliaram o padrão de condicionamento ácido da superfície do esmalte após o condicionamento com as soluções de ácido fosfórico a $37 \%$ e ácido nítrico a 2,5\% por diferentes tempos de aplicação. Foram utilizados 60 pré-molares que tiveram a superfície do esmalte condicionada com as soluções descritas acima pelos tempos de 15, 30 e 60 segundos. O ácido nítrico a 2,5\% mostrou-se menos eficiente que o ácido fosfórico a 37\% em produzir um bom padrão de condicionamento superficial. O tempo de 30 segundos de condicionamento foi considerado ideal para o ácido fosfórico a 37\%. Já para o ácido nítrico a 2,5\%, observou-se que o aumento do tempo de condicionamento proporcionava uma melhoria no padrão de condicionamento da superfície do esmalte. 
Com o objetivo de se avaliar e comparar a resistência ao cisalhamento utilizando diferentes técnicas adesivas ao esmalte, RABELLO et al. ${ }^{85}$, em 2002, utilizaram quarenta molares humanos hígidos que foram incluídos em resina epóxica. As superfícies vestibulares dos dentes foram planificadas com lixas d'água $\mathrm{n}^{\mathrm{os}} 400,600$ e 1200. Após a planificação, as superfícies foram aleatoriamente divididas em quatro grupos, cada um contendo dez dentes. No grupo 1, foi aplicado o ácido fosfórico a 37\%, por 15 segundos, lavagem com spray ar/água, por 30 segundos, secagem com ligeiro jato de ar por 2 segundos e aplicação do sistema adesivo Prime \& Bond NT em duas camadas. No grupo dois, foi aplicado o condicionador ácido não lavável NRC, por 20 segundos, secagem com jatos de ar, por 2 segundos, e aplicação do sistema adesivo Prime \& Bond NT em duas camadas. No grupo três, foi aplicado apenas o sistema adesivo Prime \& Bond NT em duas camadas. No grupo quatro, foi aplicado apenas o sistema adesivo autocondicionante Clearfil SE Bond. Após os diferentes tratamentos superficiais, cada superfície recebeu quatro incrementos de $1 \mathrm{~mm}$ da resina modificada por poliácidos DYRACT AP. As forças de resistência ao cisalhamento foram testadas na máquina de testes Instron a uma velocidade de $0,5 \mathrm{~mm} /$ minuto. Os valores médios obtidos, em MPa, foram: grupo 1: 18,78, grupo 2: 16,17, grupo 3: 17,11 e grupo 4: 15,44. Os resultados obtidos não indicaram diferença estatística entre os grupos testados.

\section{3 - Testes utilizados para mensurar valores de resistência adesiva.}

Com relação aos tipos de testes utilizados para mensurar valores de resistência adesiva, há uma grande variedade de testes realizados por diversos autores o que, 
infelizmente, impede a comparação de resultados obtidos por diferentes autores e diferentes laboratórios

Em 1989, VAN NOORT et al. ${ }^{112}$ realizaram um trabalho crítico sobre a validade dos testes de resistência adesiva. Os autores utilizaram a análise do elemento finito. Foram utilizados corpos de prova de resina, medindo $6 \mathrm{~mm}$ de altura por $6 \mathrm{~mm}$ de largura, aderidos à dentina. Entre outras análises, os autores avaliaram o efeito do carregamento sob cisalhamento na distribuição dos estresses. Os autores verificaram que a distribuição dos estresses na interface dente/restauração não é uniforme. Com relação aos testes de cisalhamento, os autores verificaram que as forças na interface aumentam quando a distância entre o ponto de aplicação da força e a superfície dentinária aumenta. Como conclusão, os autores recomendam uma padronização dos testes de resistência adesiva com o objetivo de se criar a possibilidade de comparação de dados entre diferentes trabalhos de diferentes laboratórios.

Com relação aos testes de resistência adesiva, até 1994, os testes de cisalhamento e de tração eram os mais empregados. Porém, CARVALHO et al. ${ }^{22}$, em 1994, realizaram um estudo onde os autores objetivaram avaliar e também apresentar um novo método de teste de resistência adesiva. Esse novo método foi denominado de teste de microtração. Os autores avaliaram a resistência adesiva à dentina do sistema adesivo Scotchbond Multi-Purpose e do cimento de ionômero de vidro Variglass. Para o preparo dos espécimes, os autores utilizaram terceiros molares hígidos que tiveram a porção coronária reconstruída com resina ou com ionômero e posteriormente seccionados para obtenção dos espécimes. Os espécimes foram seccionados na interface adesiva de tal modo que se criasse uma forma de ampulheta. As áreas adesivas variaram 
de $0,5 \times 0,5 \mathrm{~mm}$ a $2 \times 3 \mathrm{~mm}$. Os espécimes foram fixados em um dispositivo BencorMulti-T e submetidos aos ensaios de tração na máquina de testes Instron. Os autores observaram que os valores de resistência adesiva eram inversamente proporcionais às áreas adesivas, tanto para o sistema adesivo Scotchbond Multi-Purpose como para o cimento de ionômero de vidro Variglass.

SANO et al. ${ }^{93}$, em 1994, realizaram um estudo com o objetivo de se testar a hipótese de que não há relação entre a área da superfície adesiva e a resistência adesiva à dentina. Os autores utilizaram terceiros molares humanos que tiveram o esmalte oclusal removido e a superfície dentinária exposta. Foram realizados, então, os procedimentos adesivos na dentina com a reconstrução de um bloco de resina sobre a superfície. Em seguida, os dentes sofreram seccionamentos seriados obtendo-se, assim, fatias compostas de dentina na parte inferior e resina na superior. Essas fatias sofreram um estrangulamento na região adesiva. Foram utilizados diferentes tamanhos de área adesiva. Após a realização dos testes de tração, os resultados demonstraram que os valores de resistência adesiva foram inversamente proporcionais à área adesiva. Para uma área de $0,4 \mathrm{~mm}^{2}$, o sistema adesivo Clearfil Liner Bond apresentou uma média de resistência adesiva de $55 \mathrm{MPa}$, o sistema adesivo Scotchbond MP $38 \mathrm{MPa}$ e o ionômero de vidro Vitremer $20 \mathrm{MPa}$. Os autores observaram, ainda, que, usando pequenas áreas adesivas, todas as fraturas aconteceram na interface adesiva. Como conclusão, eles descrevem que esse novo método de microtração permite medir altos valores de resistência adesiva sem falhas coesivas em dentina, além de possibilitar a realização de mútiplas medidas dentro de um mesmo dente. 
VAN NOORT ${ }^{113}$, em 1994, abordou os aspectos relacionados com a importância e a relevância dos trabalhos laboratoriais que determinam a resistência adesiva dos materiais. $\mathrm{O}$ autor salienta a importância de se medir a resistência dos materiais primeiramente em laboratório para que se possa fazer uma relação dessa resistência com as características estruturais do material. $\mathrm{O}$ autor acredita que, assim, materiais mais resistentes possam ser desenvolvidos. Ainda com relação à importância e à relevância desses trabalhos laboratoriais, VAN NOORT ${ }^{113}$ chama a atenção para o cuidado que se deve ter ao se tentar relacionar esses dados com algum significado clínico, pois outros aspectos estão envolvidos quando se tenta fazer esta correlação.

DELLA BONA; VAN NOORT ${ }^{28}$, em 1995, realizaram um estudo com o objetivo de verificar a hipótese de que os testes de resistência adesiva, usando-se cargas de cisalhamento, não seriam adequados para se testar a adesão de resina composta aos materiais cerâmicos. Os autores realizaram o trabalho e avaliaram em uma etapa a resistência ao cisalhamento e a distribuição destas forças e, em outra etapa, a resistência à tração. Os ensaios de cisalhamento foram realizados divididos em três grupo: grupo A: (base de cerâmica aderida a uma sobrebase de resina); grupo B: (base de resina aderida a uma sobrebase de cerâmica) e grupo C: (cilindro de resina). Os espécimes para os testes de tração foram divididos em 2 grupos: grupo 1: (a superfície da cerâmica foi tratada com HF 9,6\% durante 2 minutos) e grupo 2: (a superfície da cerâmica foi tratada com APF $4 \%$ durante 2 minutos) e em ambos os grupos foram aplicados, em seguida, o silano, o sistema adesivo e a resina composta. Os resultados demonstraram que, com relação aos testes de cisalhamento, os grupos B e C apresentaram os maiores valores de resistência (respectivamente 18,02 e 21,82 MPa). Os resultados dos testes de tração demonstraram que não houve diferença estatística entre os grupos 1 e 2 
(respectivamente 13,46 e 13,43 MPa). Os autores verificaram que a distribuição do estresse nos testes de cisalhamento não é uniforme. Eles concluíram que o teste de tração é o mais apropriado para se testar a união adesiva das resinas compostas aos materiais cerâmicos.

PASHLEY et al. ${ }^{73}$, em 1995, num trabalho de revisão de literatura analisaram os tipos de testes de resistência adesiva e a validade dos valores obtidos em cada um. Os autores destacaram a realidade de que na maioria dos testes de resistência dos adesivos atuais realizados, resistências adesivas na ordem de 20 a 30 Mpa são obtidas e, na maioria das vezes, ocorrem falhas não na interface adesiva, mas, sim, dentro do dente ou do próprio material. Assim, PASHLEY et al. ${ }^{73}$ destacam a importância do teste de microtração que fornecem valores de união de até $70 \mathrm{MPa}$ e uma maior porcentagem de falhas na área adesiva. Dentre as vantagens do teste de microtração, o autor destaca: possibilidade de se medir a resistência em várias regiões, possibilidade de se medir a média e o desvio padrão em um único dente, apresentar uma maior porcentagem de falhas adesivas do que falhas coesivas, possibilidade de se medir valores de resistência adesiva mais altos do que os testes tradicionais, possibilidades de se medirem a resistência adesiva em áreas pequenas e a facilidade de se avaliar a área adesiva em microscopia eletrônica de varredura. Algumas desvantagens são citadas pelos autores como: a necessidade de se obterem equipamentos especiais, a dificuldade de preparação dos espécimes para o teste, a dificuldade de se mensurarem valores inferiores a $5 \mathrm{MPa}$ e a possibilidade de ocorrer a desidratação dos espécimes.

SHONO et al. ${ }^{97}$, em 1997, testaram a hipótese de que existe uma relação inversa entre os valores de resistência adesiva ao esmalte e a dimensão dessa área adesiva. Os 
autores ainda avaliaram a possibilidade da existência de diferenças nos valores de resistência adesiva entre diferentes regiões do esmalte. Para isso, utilizaram as superfícies vestibular e lingual de terceiros molares humanos. Essas superfícies foram desgastadas com lixas abrasivas de granulação 240 e, em seguida, foram realizados os procedimentos adesivos utilizando-se os sistemas adesivos Clearfil Liner Bond 2 ou Scotchbond Multi-Purpose Plus e as resinas Kuraray's AP-X ou Z100. Os espécimes foram estocados em água a $37^{\circ} \mathrm{C}$, por 24 horas, e secccionados verticalmente para a obtenção de 4 a 5 fatias de $1 \mathrm{~mm}$ de espessura. As fatias sofreram, então, um desgaste na área adesiva com o objetivo de se obterem espécimes com uma área de $1 \mathrm{~mm}^{2}$. Foram testadas as regiões oclusal, média e cervical das faces vestibulares e linguais. Para se avaliar a existência de uma relação inversa entre os valores de resistência adesiva ao esmalte e a dimensão dessa área adesiva, os autores realizaram os mesmos procedimentos adesivos somente no terço cervical dos dentes, variando a área adesiva $\left(0,5 ; 1,0 ; 1,5 ; 2,0 ; 2,5\right.$ e 3,0 $\mathrm{mm}^{2}$.) Após os testes de microtração, os resultados demonstraram que em ambos os sistemas adesivos houve uma inversa relação entre os valores de resistência adesiva e a área testada, assim como no trabalho de SANO et al. ${ }^{93}$, em 1994, que usaram a dentina como substrato adesivo. Os valores de resistência adesiva foram significativamente maiores no terço oclusal para ambos os sistemas adesivos.

Em 1998, SCHREINER et al. ${ }^{95}$ avaliaram se existe diferença nos valores de resistência adesiva obtidos entre um teste de cisalhamento e um teste de microtração. $\mathrm{Na}$ preparação dos espécimes para os testes de resistência às cargas de cisalhamento, foram usados 35 dentes divididos em cinco grupos, com uma área de adesão de 3,4mm de diâmetro. Para a realização dos testes de microtração, os autores utilizaram 30 dentes 
que foram divididos em cinco grupos de acordo com o sistema adesivo utilizado: Clearfil Liner Bond, Prime \& Bond, Scotchbond Multipurpose com condicionamento com ácido fosfórico a 37\%, Scotchbond Multipurpose com condicionamento com ácido maleico e Scotchbond Multipurpose Plus. Após análise dos resultados, observou-se que os valores obtidos com o teste de microtração foram significativamente maiores que os obtidos com o teste de cisalhamento. Após a análise das fraturas dos espécimes em microscopia eletrônica de varredura, observou-se que, quando se utilizou o teste de microtração, as falhas foram coesivas no próprio adesivo ou adesivas entre o adesivo e a resina composta. Quando se utilizou o teste de cisalhamento, as fraturas envolveram parcialmente a resina ou a dentina. Como conclusão, os autores preconizam o teste de microtração como um meio de se avaliar de uma forma mais efetiva a resistência adesiva.

CARDOSO; BRAGA; CARRILHO ${ }^{21}$, em 1998, realizaram um estudo com o objetivo de se determinar a resistência adesiva à dentina, de três sistemas adesivos, medida através dos testes de cisalhamento, tração e microtração. Os autores utilizaram trinta molares humanos que tiveram as superfícies de dentina expostas e lixadas com lixas de granulação 200 e 600. Foram realizados, em seguida, os procedimentos adesivos com a aplicação dos sistemas adesivos (Single Bond, Scotchbond MP e Etch \& Prime 3.0) e da resina composta (Z-100). Os testes de cisalhamento e de tração foram realizados na máquina de testes Otto Wolpert-Wercke. Após a realização dos testes de cisalhamento e de tração, os dentes tiveram uma outra superfície de dentina exposta e nesta superfície foram realizados os procedimentos adesivos para a realização do teste de microtração, este realizado na máquina de testes Kratos. Os resultados demonstraram que os valores obtidos com o teste de microtração foram estatisticamente superiores aos 
valores obtidos com os testes de cisalhamento e de tração. Os autores concluem que o teste de microtração é uma interessante alternativa e fornece novas possibilidades para o estudo da adesão.

PASHLEY et al. ${ }^{74}$, em 1999, realizaram um trabalho de revisão de literatura com o objetivo de se descrever os vários tipos e as várias modificações realizadas mos testes de microtração. Os autores descrevem que a essência do teste de microtração é a divisão do complexo adesivo resina/dente em fatias entre 0,5 a $1 \mathrm{~mm}$ de espessura e, então, proceder ao desgaste da área adesiva com o intuito de se concentrar a força de tração ao longo dessa interface durante o teste. Como vantagens do teste de microtração, os autores salientam a importância de se obterem vários espécimes através de um único dente, principalmente devido à atual dificuldade em se encontrar dentes para pesquisas. Talvez, como principal vantagem, os autores destacam o fato de que, por apresentar uma pequena área adesiva a ser testada $(1 \mathrm{~mm})$, a distribuição dos estresses durante a aplicação das cargas de tracionamento são mais uniformes nessa área adesiva, o que explica um menor número de falhas coesivas em dentina comparado aos testes tradicionais. Os autores concluem que o teste de microtração possui uma grande versatilidade, o que já não pode ser oferecido pelos testes tradicionais. 
3.PROPOSICẼO 


\section{3 - PROPOSIÇÃO}

O presente trabalho propõe testar a hipótese de que o ácido bórico a $2 \%$ pode proporcionar substratos dentinário e de esmalte com características suficientes para fornecer resistência adesiva semelhante à conseguida com o ácido fosfórico a $35 \%$. Serão utilizados testes de microtração e imagens de microscopia eletrônica de varredura para estudar, respectivamente:

a resistência à microtração de dois sistemas adesivos à dentina e ao esmalte;

o padrão de superfície condicionada desses dois substratos dentários após a aplicação das soluções ácidas descritas acima.

o padrão de superfície condicionada desses dois substratos dentários após a aplicação dos sistemas adesivos Prime\&Bond NT e Single-Bond 
4.MATERIAL E MÉTODOS 


\section{4 - MATERIAL E MÉTODOS.}

4. 1 - Ensaios de resistência adesiva.

\section{1. A - Obtenção dos dentes}

Para os ensaios de resistência adesiva, foram utilizados 48 terceiros molares humanos hígidos, os quais foram extraídos e armazenados em solução saturada de cloreto de sódio a $0,1 \%$ em timol, a uma temperatura de $4^{\circ}$, até seis meses após a data da extração. Os dentes foram extraídos e recolhidos na Faculdade de Odontologia da Universidade Federal de Juiz de Fora-MG e selecionados mediante uma autorização, por escrito, por parte do paciente, exigida pelo comitê de ética da Faculdade de Odontologia de Bauru (documentos inseridos nos anexos).

\section{1. B - Sistemas restauradores}

Como agentes condicionadores ácidos foram utilizados o ácido fosfórico a 35\% (Dentisply AS), uma solução de ácido bórico a 2\% e uma solução de ácido bórico a 2\% em forma de gel. As soluções de ácido bórico foram manipuladas no Departamento de Bioquímica da Faculdade de Odontologia de Bauru. Foram utilizados, ainda, os sistemas adesivos de frasco único Single-Bond (3M) e Prime \& Bond NT (Dentisply) e as resinas compostas Z-250 (3M) e TPH-Spectrum (Dentisply) (Quadro 1). 
Quadro 1. Materiais utilizados para os testes de resistência adesiva e seus respectivos fabricantes.

\begin{tabular}{|c|c|c|c|}
\hline $\begin{array}{c}\text { Agente } \\
\text { Condicionador }\end{array}$ & Sistema Adesivo & Resina Composta & Fabricante \\
\hline $\begin{array}{l}\text { Ácido Fosfórico } \\
\text { 35\% } \\
\text { Gel pH }(1,0) \\
\text { Dióxido de Silício }\end{array}$ & $\begin{array}{c}\text { Single-Bond } \\
\text { pH(4.6) } \\
\text { Bis-GMA, HEMA, uretano } \\
\text { dimetacrilatos, etil-4- } \\
\text { dimetilaminobenzoato, } \\
\text { glicerol dimetacrilato, } \\
\text { difeniliodo-hexaflúorfosfato, } \\
\text { copolímero de ácido } \\
\text { policarboxílico, } \\
\text { canforoquinona, água, etanol }\end{array}$ & $\begin{array}{c}\text { Z-250 } \\
\text { Bis-GMA,bisfenol glicidil } \\
\text { metacrilato, TEGDMA, } \\
\text { trietileno glicol } \\
\text { dimetacrilato } \\
\text { ZIRCÔNIA /SÍLICA }\end{array}$ & 3M - Brasil \\
\hline $\begin{array}{c}\text { Ácido Fosfórico } \\
\mathbf{3 5 \%} \\
\text { Gel pH (1.0) } \\
\text { Dióxido de Silício }\end{array}$ & $\begin{array}{l}\text { Prime\&Bond NT } \\
\qquad \text { pH (1.9) } \\
\text { PENTA, UDMA + resina-T } \\
\text { + resina-D, hidroxitolueno } \\
\text { butilado, aminobenzoato 4- } \\
\text { etil dimetacrilato, } \\
\text { hidrofluoreto de cetilamina, } \\
\text { acetona, nanopartículas de } \\
\text { sílica }\end{array}$ & $\begin{array}{l}\text { TPH Spectrum } \\
\text { Bis-GMA, Bisfenol-A- } \\
\text { dimetacrilato etoxilado, } \\
\text { trietileno glicol } \\
\text { dimetacrilato }\end{array}$ & Dentsply - Brasil \\
\hline $\begin{array}{c}\text { Ácido Bórico 2\% } \\
\text { Solução pH(4,8) } \\
\begin{array}{c}\text { Gel pH (2.9) } \\
\text { Carbopol }\end{array}\end{array}$ & $\begin{array}{c}\text {-- Single-Bond } \\
\text { pH(4.6) } \\
\text { Prime\&Bond NT } \\
\text { pH (1.9) }\end{array}$ & $\begin{array}{c}\text { Z-250 } \\
\text { TPH Spectrum }\end{array}$ & Experimental \\
\hline
\end{tabular}

4. 1. C - Preparo dos espécimes para o ensaio de resistência adesiva em dentina.

Para os ensaios de resistência adesiva em dentina, foram utilizados vinte e quatro terceiros molares. Em doze dentes utilizaram-se o sistema adesivo Single-Bond e a resina composta Z-250 em associação com os diferentes tratamentos superficiais da dentina. Estes foram divididos em cinco grupos, de acordo com os seus diferentes tratamentos. Nos outros doze dentes foram utilizados o sistema adesivo Prime \& Bond NT e a resina composta TPH. Esses foram divididos em seis grupos, de acordo com os seus diferentes tratamentos. 
Quadro 2 - Grupos para os ensaios de resistência adesiva na dentina com os respectivos agentes condicionadores, tempos de condicionamento, sistemas adesivos e materiais restauradores.

\begin{tabular}{|c|c|c|c|c|c|}
\hline GRUPOS & $\begin{array}{c}\text { NÚMERO } \\
\text { DE } \\
\text { DENTES }\end{array}$ & $\begin{array}{c}\text { AGENTE } \\
\text { CONDICIONADOR }\end{array}$ & TEMPO DE COND. & $\begin{array}{l}\text { SISTEMA } \\
\text { ADESIVO }\end{array}$ & MAT. REST \\
\hline GRUPO 1 & 2 & ÁC. FOSFÓRICO 35\% & 15 SEGUNDOS & SINGLE-BOND & $\mathrm{Z}-250$ \\
\hline GRUPO 2 & 2 & $\begin{array}{l}\text { ÁC. BÓRICO } 2 \% \\
\text { SOLUÇÃO }\end{array}$ & 30 SEGUNDOS & SINGLE-BOND & $\mathrm{Z}-250$ \\
\hline GRUPO 3 & 2 & $\begin{array}{l}\text { ÁC. BÓRICO 2\% } \\
\text { SOLUÇÃO }\end{array}$ & 1 MINUTO & SINGLE-BOND & $\mathrm{Z}-250$ \\
\hline GRUPO 4 & 2 & $\begin{array}{l}\text { ÁC. BÓRICO } 2 \% \\
\text { GEL }\end{array}$ & 30 SEGUNDOS & SINGLE-BOND & $\mathrm{Z}-250$ \\
\hline GRUPO 5 & 2 & $\begin{array}{c}\text { ÁC. BÓRICO } 2 \% \\
\text { GEL }\end{array}$ & 1 MINUTO & SINGLE-BOND & $\mathrm{Z}-250$ \\
\hline GRUPO 6 & 2 & --------------- & ------------- & SINGLE-BOND & $\mathrm{Z}-250$ \\
\hline GRUPO 7 & 2 & ÁC. FOSFÓRICO 35\% & 15 SEGUNDOS & $\begin{array}{c}\text { PRIME \&BOND } \\
\text { NT }\end{array}$ & TPH \\
\hline GRUPO 8 & 2 & $\begin{array}{l}\text { ÁC. BÓRICO } 2 \% \\
\text { SOLUÇÃO }\end{array}$ & 30 SEGUNDOS & $\begin{array}{c}\text { PRIME \&BOND } \\
\text { NT }\end{array}$ & TPH \\
\hline GRUPO 9 & 2 & $\begin{array}{l}\text { ÁC. BÓRICO 2\% } \\
\text { SOLUÇÃO }\end{array}$ & 1 MINUTO & $\begin{array}{c}\text { PRIME \&BOND } \\
\text { NT }\end{array}$ & TPH \\
\hline GRUPO 10 & 2 & $\begin{array}{c}\text { ÁC. BÓRICO } 2 \% \\
\text { GEL }\end{array}$ & 30 SEGUNDOS & $\begin{array}{c}\text { PRIME \&BOND } \\
\text { NT }\end{array}$ & TPH \\
\hline GRUPO 11 & 2 & $\begin{array}{c}\text { ÁC. BÓRICO } 2 \% \\
\text { GEL }\end{array}$ & 1 MINUTO & $\begin{array}{c}\text { PRIME \&BOND } \\
\text { NT }\end{array}$ & TPH \\
\hline GRUPO 12 & 2 & -------------- & -------------- & $\begin{array}{c}\text { PRIME \&BOND } \\
\text { NT }\end{array}$ & TPH \\
\hline
\end{tabular}

Após a determinação dos grupos, cada dente foi fixado a uma base de resina acrílica, pela raiz, com auxílio de cera pegajosa (Kerr). A base de resina foi adaptada à máquina de corte (EXTEC Corporation, LABCUT, 1010, USA.). Cada dente foi submetido a um corte perpendicular, ao longo eixo da coroa dentária, com o objetivo de se expor a superfície da dentina (Fig. 1-A). Esse corte foi realizado com o auxílio de um disco diamantado (EXTEC Corporation, XL-12205,USA) aproximadamente a meia distância entre as projeções do esmalte oclusal e os cornos pulpares obtendo-se, assim, uma superfície dentinária plana e regular. Em seguida, essa superfície foi lixada na 
lixadeira Politriz (FORTER Indústria \& Comércio LTDA, BRASIL.) utilizando as lixas de carbeto de silício, de granulação 320, 600 e 1200, (PNEHLER LTDA. ILLINOIS, USA) respectivamente, durante 20 segundos com o objetivo de se padronizar a "smear layer" e eliminar resíduos eventuais de esmalte.

As superfícies dentinárias foram, então, tratadas para receber os sistemas restauradores seguindo as instruções dos respectivos fabricantes (Fig. 1-B). As coroas dentárias foram reconstruídas com resina composta seguindo o perfil anatômico externo do remanescente dentário, definindo uma superfície oclusal plana e perpendicular ao seu longo eixo (Fig. 1-C). Esses procedimentos, assim como as etapas subseqüentes de seccionamento seriado das coroas dentárias, seguiram o método descrito por SANO et al. ${ }^{93}$, em 1994. As resinas compostas foram aplicadas em incrementos e polimerizadas por 40 segundos com fotoativador (Visilux, 3M Dental Division, St. Paul, MN., USA), medido para $400 \mathrm{mw} / \mathrm{cm}^{2}$ a $500 \mathrm{mw} / \mathrm{cm}^{2}$, potência esta verificada após término de cada grupo com o auxílio de um radiômetro (Demetron Research Corp. USA Model 100 Curing Radiometer). Posteriormente, os dentes foram armazenados por 24 horas em água deionizada a $37^{\circ} \mathrm{C}$ e, então, submetidos a seccionamentos seriados verticais no sentido vestíbulo-lingual da coroa dentária, a intervalos de $1 \mathrm{~mm}$ de espessura. Estes seccionamentos foram realizados na máquina de corte EXTEC através de um disco diamantado (EXTEC Corporation, XL-12205,USA) em rotação lenta e refrigeração abundante com água (Fig. 1-D). Esses seccionamentos proporcionaram cerca de 5 a 7 fatias formadas por resina composta na porção superior e dentina na parte inferior. A seguir, as fatias foram secionadas ao meio no sentido transversal ao plano de corte inicial (Fig.1-E). Assim, cada fatia proporcionou dois espécimes compostos por resina na porção superior e dentina na porção inferior (Fig. 1-F). Em seguida, estes foram desgastados com auxílio de uma ponta diamantada cilíndrica n 1090 (KG Sorensen, SP, 
Brasil), em alta velocidade, para formar um estrangulamento na junção dentina/material restaurador, com o objetivo de se obter corpos de prova com áreas de adesão de, aproximadamente, $1 \mathrm{~mm}^{2}$ (Fig.1.G). Os corpos de prova, assim obtidos, foram armazenados em água por, no máximo 24 horas, até o momento dos ensaios de microtração (Fig.1.H).
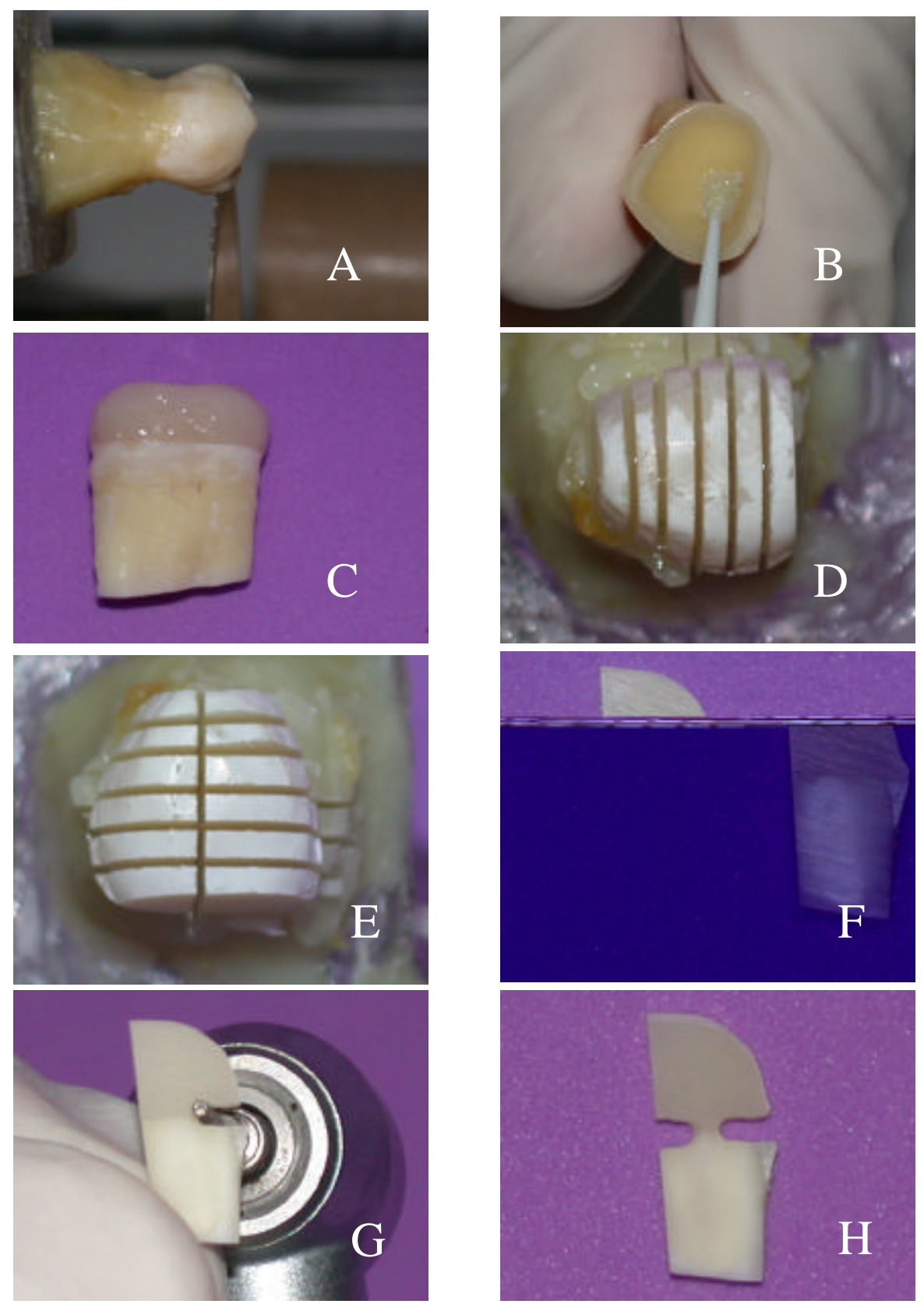

FIGURA 1 - A) Corte perpendicular ao longo eixo do dente; B) Aplicação do sistema adesivo; C) Coroa reconstruída; D,E) Vista oclusal do dente após os seccionamentos seriados; F) Espécime composto por resina na porção superior e dentina na inferior; G) Estrangulamento na junção dente/material restaurador com ponta diamantada $\left.n^{\circ} 1090 ; H\right)$ Espécime pronto para 0 teste de microtração. 

esmalte.

4. 1. D - Preparo dos espécimes para os ensaios de resistência adesiva em

Para os ensaios de resistência adesiva em esmalte, foram utilizados vinte e quatro terceiros molares. Em doze dentes, foram utilizados o sistema adesivo SingleBond e a resina composta Z-250 em associação com os diferentes tratamentos superficiais do esmalte. Estes foram divididos em seis grupos, de acordo com os seus diferentes tratamentos. Nos outros doze dentes, foram utilizados o sistema adesivo Prime \& Bond NT e a resina composta TPH. Estes também foram divididos em seis grupos, de acordo com os seus diferentes tratamentos.

Quadro 4 - Grupos para os ensaios de resistência adesiva no esmalte e os respectivos agentes condicionadores, tempos de condicionamento, sistemas adesivos e materiais restauradores.

\begin{tabular}{|c|c|c|c|c|c|}
\hline GRUPOS & $\begin{array}{l}\text { NÚMERO } \\
\text { DE DENTES }\end{array}$ & $\begin{array}{c}\text { AGENTE } \\
\text { CONDICIONADOR }\end{array}$ & TEMPO DE COND. & $\begin{array}{l}\text { SISTEMA } \\
\text { ADESIVO }\end{array}$ & MAT. REST. \\
\hline GRUPO 1 & 2 & ÁC. FOSFÓRICO 35\% & 30 SEGUNDOS & SINGLE-BOND & $\mathrm{Z}-250$ \\
\hline GRUPO 2 & 2 & $\begin{array}{l}\text { ÁC. BÓRICO 2\% } \\
\text { SOLUÇÃO }\end{array}$ & 30 SEGUNDOS & SINGLE-BOND & $\mathrm{Z}-250$ \\
\hline GRUPO 3 & 2 & $\begin{array}{l}\text { ÁC. BÓRICO 2\% } \\
\text { SOLUÇÃO }\end{array}$ & 1 MINUTO & SINGLE-BOND & $\mathrm{Z}-250$ \\
\hline GRUPO 4 & 2 & ÁC. BÓRICO $2 \%$ GEL & 30 SEGUNDOS & SINGLE-BOND & $\mathrm{Z}-250$ \\
\hline GRUPO 5 & 2 & ÁC. BÓRICO $2 \%$ GEL & 1 MINUTO & SINGLE-BOND & $\mathrm{Z}-250$ \\
\hline GRUPO 6 & 2 & ---------------- & --------------- & SINGLE-BOND & $\mathrm{Z}-250$ \\
\hline GRUPO 7 & 2 & ÁC. FOSFÓRICO 35\% & 30 SEGUNDOS & $\begin{array}{c}\text { PRIME \&BOND } \\
\text { NT }\end{array}$ & TPH \\
\hline GRUPO 8 & 2 & $\begin{array}{c}\text { ÁC. BÓRICO 2\% } \\
\text { SOLUÇÃO }\end{array}$ & 30 SEGUNDOS & $\begin{array}{c}\text { PRIME \&BOND } \\
\text { NT } \\
\end{array}$ & TPH \\
\hline GRUPO 9 & 2 & $\begin{array}{c}\text { ÁC. BÓRICO 2\% } \\
\text { SOLUÇÃO }\end{array}$ & 1 MINUTO & $\begin{array}{c}\text { PRIME \&BOND } \\
\text { NT }\end{array}$ & TPH \\
\hline GRUPO 10 & 2 & ÁC. BÓRICO $2 \%$ GEL & 30 SEGUNDOS & $\begin{array}{c}\text { PRIME \&BOND } \\
\text { NT } \\
\end{array}$ & TPH \\
\hline GRUPO 11 & 2 & ÁC. BÓRICO $2 \%$ GEL & 1 MINUTO & $\begin{array}{c}\text { PRIME \&BOND } \\
\text { NT }\end{array}$ & TPH \\
\hline GRUPO 12 & 2 & ----------------- & - & $\begin{array}{c}\text { PRIME \&BOND } \\
\text { NT }\end{array}$ & TPH \\
\hline
\end{tabular}


Para os testes de resistência adesiva no esmalte, as faces vestibular e lingual dos molares foram previamente planificadas com auxílio de uma ponta diamantada $\mathrm{n}^{\mathrm{o}} 4138$ (KG SORENSEN) para proporcionar uma superfície plana de, aproximadamente, $8 \mathrm{~mm}$ x 5mm (Fig. 2-A). As superfícies sofreram posterior regularização com lixas de carbeto de silício (PNEHLER LTDA. ILLINOIS, USA), de granulação 320, 600 e 1200, na politriz (FORTER Indústria \& Comércio LTDA, BRASIL.) sob refrigeração a água (Fig. 2-B) . A partir das superfícies assim preparadas, foram erguidos blocos de resina composta nas faces vestibular e lingual das coroas dentárias (Fig.2-D,E) seguindo-se os mesmos procedimentos de adesão adotados para os testes em dentina, exceto para o condicionamento com ácido fosfórico que teve duração de 30 segundos (Fig. 2-C). Posteriormente, os dentes foram armazenados por 24 horas em água deionizada a $37^{\circ} \mathrm{C}$ e, então, submetidos a seccionamentos seriados verticais no sentido vestíbulo-lingual da coroa dentária, a intervalos de 0,8 mm de espessura (Fig. 2-F). Esses seccionamentos foram realizados na máquina de corte EXTEC, através de um disco diamantado em rotação lenta e refrigeração abundante com água. Os seccionamentos proporcionaram cerca de 5 a 7 fatias. A seguir, as fatias foram seccionadas ao meio no sentido transversal ao plano de corte inicial conforme os procedimentos de SHONO et al. ${ }^{97}$, em 1997 (Fig. 2-G). Assim, cada fatia proporcionou dois espécimes compostos de resina composta na porção superior e esmalte na parte inferior (Fig. 2-H). Em seguida, estes foram desgastados com auxílio de uma ponta diamantada cilíndrica $\mathrm{n}^{\mathrm{o}} 1090$ (KG Sorensen, SP, Brasil), em alta velocidade, formando um estrangulamento na junção esmalte/material restaurador com o objetivo de se obter corpos de prova com áreas de adesão de, aproximadamente, $0,8 \mathrm{~mm}^{2}$ (Fig. 2-I). Os corpos de prova, assim obtidos, foram armazenados em água até o momento dos ensaios de microtração (Fig.2-J). 

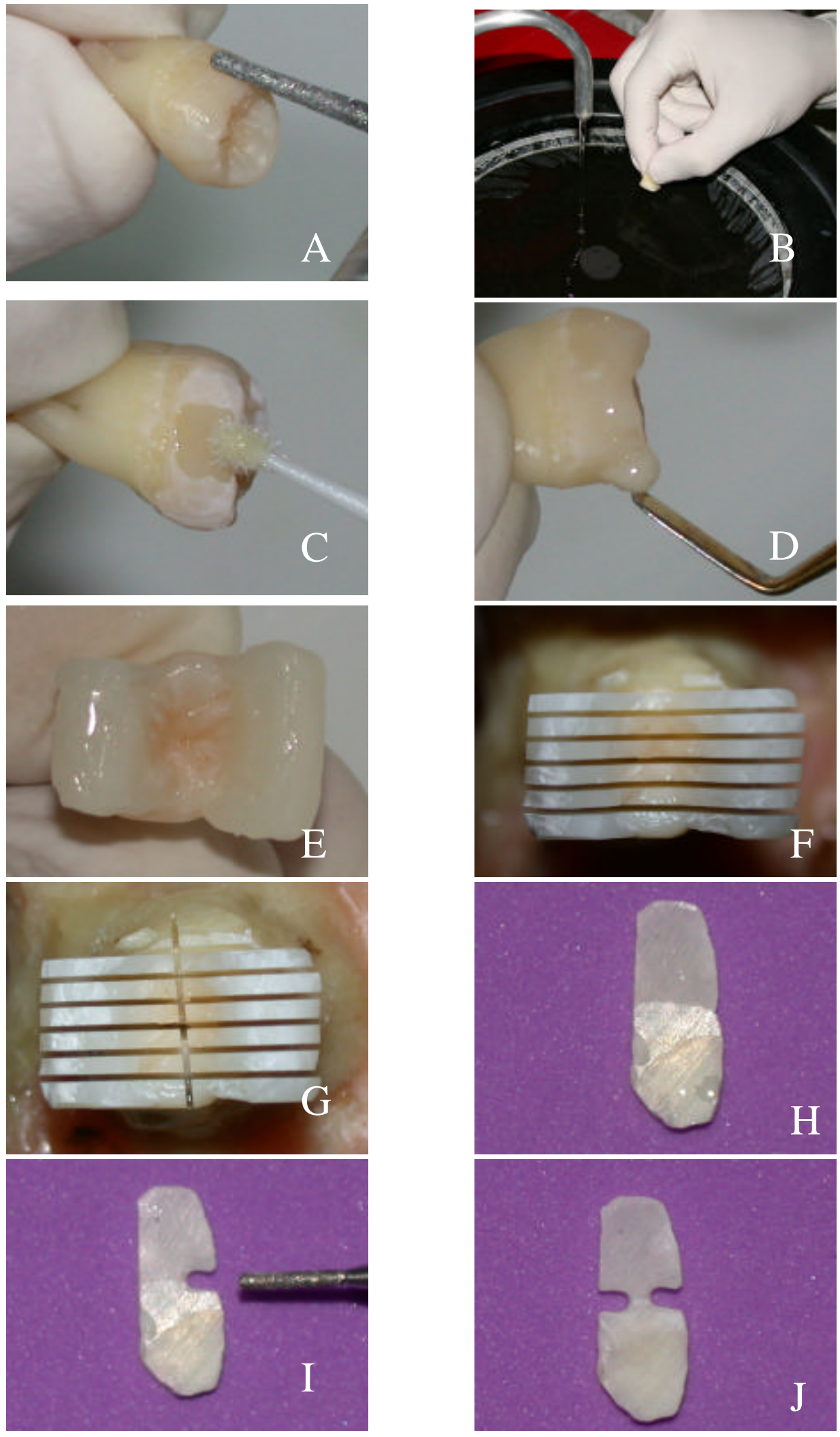

FIGURA 2 - A) Planificação das superfícies vestibular e lingual dos molares; B) Padronização da "smear layer". C) Aplicação do sistema adesivo; D)Aplicação da resina composta pela técnica incremental; E) Blocos de resina sobre as superfícies vestibular e lingual; F) Cortes no sentido vestíbulolingual da coroa; G) Corte no sentido transversal ao corte inicial; H) Espécime composto por resina na porção superior e esmalte na inferior; I) Estrangulamento na junção dente/material restaurador com uma ponta diamantada $\mathrm{n}^{0} 1090 ; \mathrm{J}$ ) Espécime pronto para o teste de microtração. 


\section{1. E - Testes de microtração}

Em média, foram testados 17 espécimes para cada grupo, na dentina, e 18 no esmalte. Cada espécime foi fixado pelos seus extremos aos extensores da máquina de testes EMIC (DL 500 DF NO 5775 NS 168), através do dispositivo Bencor Mult-T (Danville Engeneering, Danville,CA,USA), com adesivo à base de cianoacrilato (QuickTite - Loctite 14 OZ) (Fig.3-A,B,C,D) e seu respectivo acelerador (7452 Superbonder Loctite,USA). A velocidade de tração foi fixada em 0,5 mm/min.
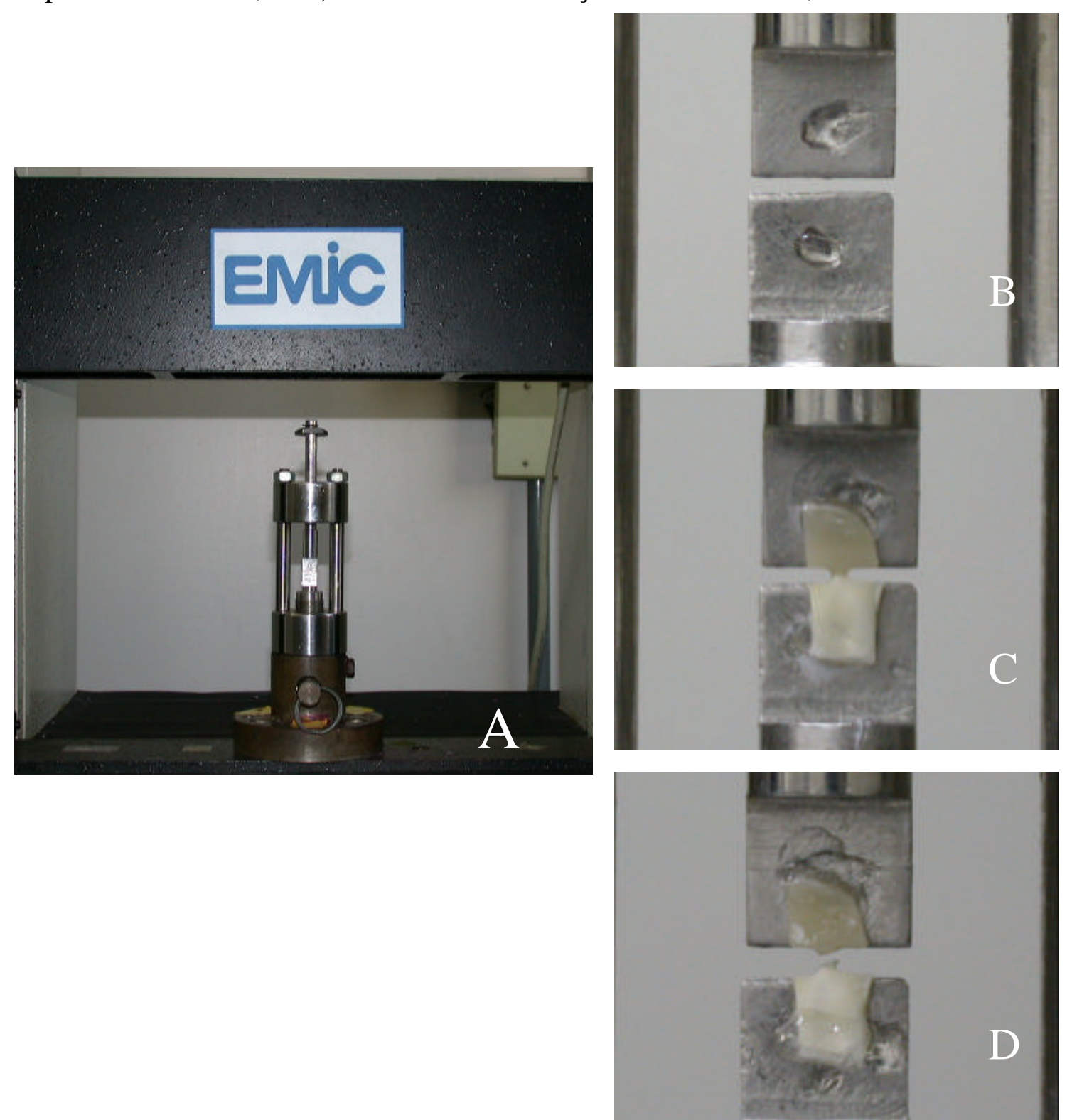

FIGURA 3 - A) Dispositivo (Mult-T, Bencor, USA) adaptado à máquina de ensaios universal (EMIC); B) Aplicação do adesivo a base de cianocrilato; C) Espécime de dentina fixado no dispositivo; D) Espécime de dentina fraturado após a realização do teste. 
As forças de tração correspondentes à fratura foram divididas pelas respectivas áreas de secção para possibilitar o cálculo das tensões em MPa de acordo com a seguinte fórmula: Kgf/área adesiva x constante $(0,0981)=$ resistência adesiva em MPa. Após a fratura, foram selecionados espécimes para observação em MEV e estereomicroscopia para análise do modo de fratura.

\section{1. F - Análise estatística}

Utilizou-se o teste de análise de variância (ANOVA) para a verificação de possíveis diferenças estatísticas entre os grupos. Observadas as diferenças estatísticas, empregou-se o teste Tukey objetivando uma comparação individual. Em ambos os testes foi adotado um nível de significância de $5 \%(\mathrm{p}<0,05)$.

4. 2 - Estudo do padrão de condicionamento superficial através de Microscopia Eletrônica de Varredura. (MEV)

Para o estudo em microscopia eletrônica de varredura, foram utilizados 18 terceiros molares recém extraídos. Os dentes foram armazenados em solução saturada de cloreto de sódio a $0,1 \%$ em timol, a uma temperatura de $4^{\circ}$, até seis meses após a data da extração. O processo de obtenção dos dentes seguiu os mesmos procedimentos descritos anteriormente para a avaliação da resistência adesiva (documentos inseridos nos anexos).

4. 2. A - Obtenção dos espécimes de dentina.

Para o estudo em microscopia eletrônica de varredura em dentina, foram usados nove molares. Estes tiveram suas coroas seccionadas no sentido transversal ao seu eixo 
longitudinal, a partir da superfície oclusal, com disco diamantado montado em uma máquina de corte, considerando os detalhes descritos para obtenção dos espécimes para testes de microtração em dentina (Fig. 4A). Em seguida, foi realizado um segundo seccionamento para a obtenção de um disco de dentina a partir da porção média da coroa dentária (Fig. 4-B). Os discos de dentina, assim obtidos, foram desgastados com lixas de carbeto de silício de granulação 600 e 1200, montada em politriz sob irrigação contínua, com o objetivo de eliminar resíduos eventuais de esmalte, regularizar a superfície dentinária e produzir uma "smear layer" padronizada. Cada dente produziu um único disco de dentina, com espessura aproximada de 1,0 $\mathrm{mm}$, aferido por um paquímetro (Mitutoyo, Japan) (Fig. 4-C) .

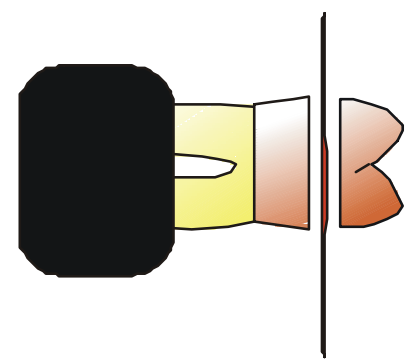

A

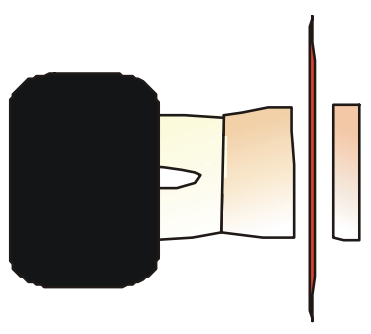

B

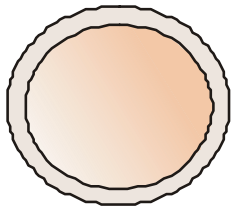

$\mathrm{C}$

FIGURA 4 - A) Corte perpendicular ao longo eixo do dente; B) Segundo corte para obtenção do disco de dentina; C) Disco de dentina.

4. 2. B - Obtenção dos espécimes de esmalte.

Para o estudo em microscopia eletrônica de varredura, em esmalte, foram usados nove molares. As superfícies vestibulares dos molares foram planificadas com lixas de carbeto de silício de granulação 600 e 1200 para remover o esmalte superficial e 
produzir área apropriada para a realização dos testes com os agentes condicionadores (Fig. 5-A). As coroas dentárias, assim preparadas, foram recortadas no formato quadrangular com pontas diamantadas cilíndricas (n $\mathrm{n}^{0}$ 4138, KG Sorensen) (Fig. 5-B), obtendo-se de cada coroa dentária um espécime da região vestibular de, aproximadamente, 4,0 x 4,0 $\mathrm{mm}$ padronizando, assim, a região do dente e o tamanho do espécime de esmalte (Fig. 5-C).

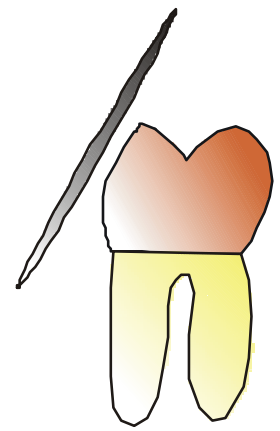

A

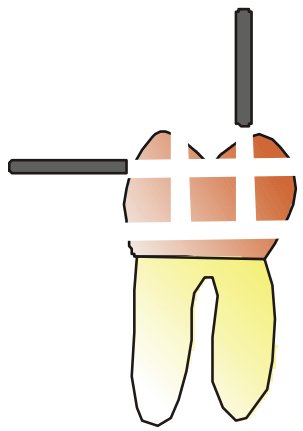

B

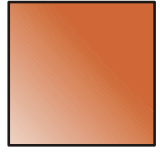

$\mathrm{C}$

FIGURA 5 - A) Planificação da superfície vestibular dos molares; B) desgaste com pontas diamantadas para obtenção do espécime quadrangular de esmalte; C) Espécime de esmalte.

\section{2. C - Padronização da "smear layer".}

Imediatamente antes da aplicação dos agentes condicionadores, os espécimes foram desgastados em um politriz com lixas 600 e 1200 de carbeto de silício, com irrigação constante, promovendo, assim , uma padronização da "smear layer".

Em seqüência, os espécimes foram divididos em quadrantes, com o auxílio de um estilete, e submetidos aos tratamentos superficiais descritos a seguir (Fig.6-A,B,C). 


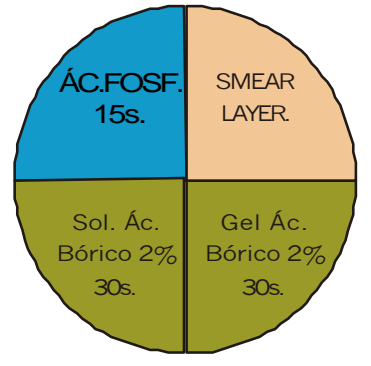

A

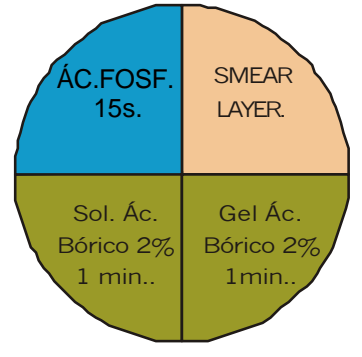

B

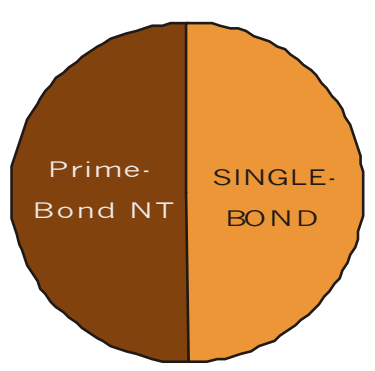

$\mathrm{C}$

FIGURA 6 - A,B,C) Esquema demonstrativo da divisão dos discos de dentina em quadrantes com os seus respectivos tratamentos superficiais.

Antes da aplicação das soluções ácidas, era realizada uma marcação com uma ponta diamantada $n^{\circ} 1090$ na borda de cada espécime para a identificação futura dos quadrantes. Os tratamentos para o esmalte foram idênticos aos da dentina, diferindo, apenas, para o tempo de condicionamento com o ácido fosfórico, que foi de 30 segundos. Os agentes condicionadores foram aplicados sobre a superfície da dentina e do esmalte pelos tempos determinados para cada tipo de solução e, em seguida, removidos com água deionizada pelos mesmos tempos. No grupo onde foram utilizados os sistemas adesivos, não foi realizado condicionamento ácido das superfícies. Os sistemas adesivos foram aplicados seguindo as orientações dos fabricantes e, após a aplicação da última camada, eles foram removidos após o uso de uma solução à base de acetona pelo tempo de 60 segundos e, então, lavados com água por 15 segundos ${ }^{97}$. Para que isso pudesse ser feito, os adesivos não poderiam ser polimerizados.

4. 2. D - Desidratação e fixação dos espécimes.

Os discos de dentina e os espécimes de esmalte foram preparados para microscopia eletrônica de varredura seguindo a técnica proposta por PERDIGÃO et 
al. ${ }^{78}$, em 1995. Imediatamente após o condicionamento ácido, os discos foram lavados e imersos em uma solução de glutaraldeído a 2,5\% (Sigma Chemical CO. St. Louis, Michican, USA.) em solução tampão de cacodilato de sódio a 0,1M (Sigma Chemical CO. St. Louis, Michigan, USA) $\mathrm{pH}$ 7,4, por 12 horas, a $4^{\circ} \mathrm{C}$, para fixar as estruturas a serem analisadas. Após esse período, os espécimes foram lavados com solução tampão de cacodilato de sódio a $0,2 \mathrm{M}, \mathrm{pH} 7,4$, em três trocas de solução, por 1 hora, e lavados com água deionizada por 1 minuto. Em seguida, os espécimes foram desidratados através da imersão em soluções alcoólicas na sequinte ordem: álcool a $25 \%$ por 20 minutos, álcool a $50 \%$ por 20 minutos, álcool a $75 \%$ por 20 minutos, álcool a 95\% por 30 minutos e álcool a $100 \%$ por 1 hora. Posteriormente, os espécimes foram imersos em solução de hexametil-di-silasano (HMDS) (Sigma Chemical CO. St. Louis, Michigan, USA), por 10 minutos, procedendo-se à secagem com papel absorvente e mantidos no interior de um recipiente de vidro, em temperatura ambiente, para secagem espontânea. As amostras foram, então, metalizadas no metalizador (HUMMER VIII SPOOTTERIG SYSTEM - ANATC EDT Alexandria, VA, USA.) com ouro, a uma espessura de 15 nm. Após a metalização, os espécimes foram levados ao microscópio eletrônico de varredura (ZEISS GERMANY DSM 940 A) para serem observados nos aumentos de 2000X.

\section{2. E - Critérios para Análise em MEV}

Os espécimes foram analisados segundo critérios adotados por PEREIRA; CASTRO ${ }^{81}$, em 1998, considerando: a capacidade de remoção da "smear layer", a exposição das fibras colágenas na superfície da dentina, as características da dentina peritubular e a presença de "smear plugs". 
5. RESULTADOS 


\section{5 - RESULTADOS}

5. 1 - Resultados dos ensaios de resistência adesiva.

Após os testes de microtração, os valores das áreas adesivas dos grupos 1 a 6 e 7 a 12, tanto na dentina como no esmalte, foram submetidos ao teste de análise de variância a um critério (ANOVA) com um nível de significância de 5\% para a verificação de possíveis diferenças estatísticas. Foi verificado, então, que, na dentina, existiam diferenças estatísticas significantes entre os grupos 1 a 5. Assim, aplicourse o teste Least-Squares Means com o objetivo de ajustar as áreas desses grupos para $0,95 \mathrm{~mm}^{2}$. Após o ajuste das áreas, os valores de resis tência adesiva de todos os grupos, medidos em MPa, foram submetidos à análise estatística. Foi utilizado o teste de análise de variância a um critério ANOVA com um nível de significância de 5\% ( $<<0,05 \%)$ para a verificação de possíveis diferenças estatísticas entre os valores de resistência adesiva. Os grupos que apresentaram diferenças estatísticas foram submetidos ao teste de Tukey.

5. 1 - A - Resultados dos ensaios de resistência adesiva em dentina

Quando se utilizaram o sistema adesivo Single-Bond e a resina composta Z-250, o resultado dos valores de resistência adesiva obtido demonstrou que houve diferença estatística significante entre os grupos (Tabela 1). A ordem decrescente dos valores de resistência adesiva foi: Grupo 1: 41,88; Grupo 3: 16,10; Grupo 2: 15,05; Grupo 5: 10,59 e Grupo 4: 5,93 MPa. O grupo 1, o qual recebeu o tratamento superficial da dentina com o ácido fosfórico a $35 \%$ por 15 segundos, apresentou valores de resistência adesiva estatisticamente superior aos dos demais grupos. Os grupos 2, 3 e 5 não apresentaram diferenças estatísticas significantes entre si, porém apresentaram valores 
estatisticamente superiores aos do grupo 4. Os valores dos grupos 4 e 5 não apresentaram diferenças estatísticas significantes entre si. Não foi possível avaliar os valores de resistência do grupo 6 pois todos os espécimes se fraturaram durante os procedimentos de corte.

Tabela 1 - Resultados estatísticos referentes aos grupos onde foram utilizados o sistema adesivo Single-Bond e a resina composta Z-250 em associação com os diferentes tratamentos superficiais da dentina.

\begin{tabular}{|c|c|c|c|}
\hline & $\mathrm{n}$ testados & $\mathrm{n}^{*}$ & Média Resistência adesiva (D.P.) \\
\hline Grupo 1 & 20 & 02 & $41,88^{\mathrm{a}}(6,22)$ \\
\hline Grupo 2 & 15 & 08 & $15,05^{\mathrm{b}}(6,69)$ \\
\hline Grupo 3 & 19 & 05 & $16,10^{\mathrm{b}}(6,55)$ \\
\hline Grupo 4 & 11 & 11 & $5,93^{\mathrm{c}}(2,45)$ \\
\hline Grupo 5 & 14 & 06 & $10,59^{\mathrm{b}, \mathrm{c}}(4,29)$ \\
\hline Grupo 6 & -- & -- & ---------- \\
\hline
\end{tabular}

n*: $\mathrm{n}$ perdidos durante o preparo dos espécimes para os testes de resistência adesiva.

\begin{tabular}{|ll|}
\hline$\square$ Ác. Fosf. 35\% 15s & $\square$ Sol. Ác. Bórico 2\% 30s \\
$\square$ Sol. Ác. Bórico 2\% 1min & $\square$ Gel Ác. Bórico 2\% 30s \\
$\square$ Gel Ác. Bórico 2\% 1min & $\square$ SB sem condicionamento \\
\hline
\end{tabular}

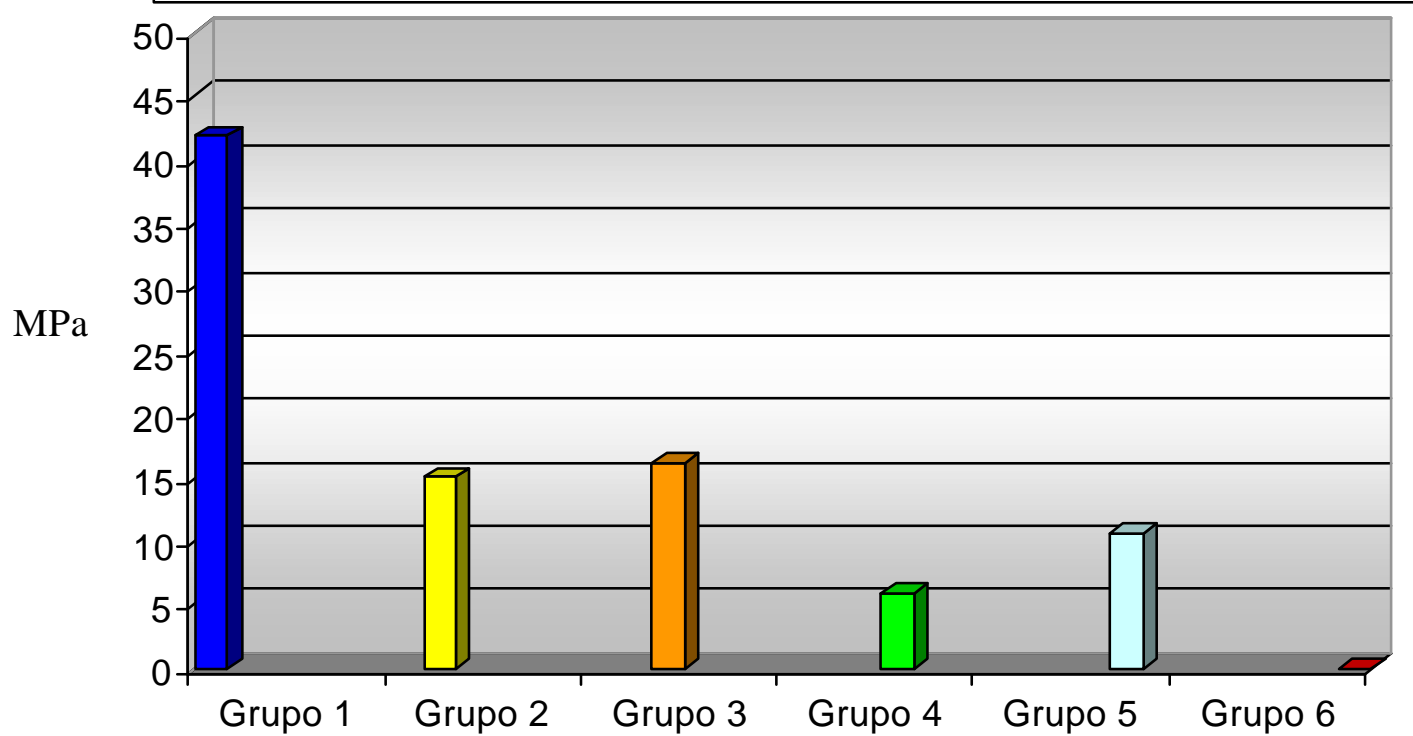

Figura 7 - Gráfico - Médias dos valores de resistência adesiva utilizando o sistema adesivo Single-Bond e a resina composta Z-

250 com os diferentes tratamentos superficiais da dentina. 
Já nos grupos onde foram utilizados o sistema adesivo Prime \& Bond NT (PBNT) e a resina composta (TPH) com os diferentes tratamentos superficiais da dentina, o resultado dos valores de resistência adesiva demonstrou que houve diferença estatística significante entre os grupos (Tabela 2). A ordem decrescente dos valores de resistência adesiva foi: Grupo 12: 34,80; Grupo 7: 32,74; Grupo 8: 29,52; Grupo 9: 29,28; Grupo 10: 25,27 e Grupo 11: 25,23 MPa.

Tabela 2 - Resultados estatísticos referentes aos grupos onde foram utilizados o sistema adesivo Prime-Bond NT (PBNT) e a resina composta (TPH) em associação com os diferentes tratamentos superficiais da dentina.

\begin{tabular}{|c|c|c|c|}
\hline & n testados & $\mathrm{n}^{*}$ & Média Resistência adesiva. (D.P.) \\
\hline Grupo 7 & 19 & 05 & $32,74^{\mathrm{a}, \mathrm{b}}(8,48)$ \\
\hline Grupo 8 & 15 & 08 & $29,52^{\mathrm{a}, \mathrm{b}}(10,75)$ \\
\hline Grupo 9 & 18 & 05 & $29,28^{a, b}(13,18)$ \\
\hline Grupo 10 & 18 & 05 & $25,27^{\mathrm{a}, \mathrm{c}}(5,89)$ \\
\hline Grupo 11 & 20 & 08 & $25,23^{\mathrm{a}, \mathrm{c}}(8,93)$ \\
\hline Grupo 12 & 19 & 05 & $34,80^{\mathrm{b}} \quad(8,48)$ \\
\hline
\end{tabular}

$\mathrm{n}^{*}: \mathrm{n}$ perdidos durante o preparo dos espécimes para os testes de resistência adesiva. 
口Ác. Fosf. 35\% 15s

$\square$ Sol. Ác. Bórico 2\% $1 \mathrm{~min}$

$\square$ Gel Ác. Bórico 2\% $1 \mathrm{~min}$ $\square$ Sol. Ác. Bórico 2\% 30s

$\square$ Gel Ác. Bórico 2\% 30s

PBNT sem condicionamento

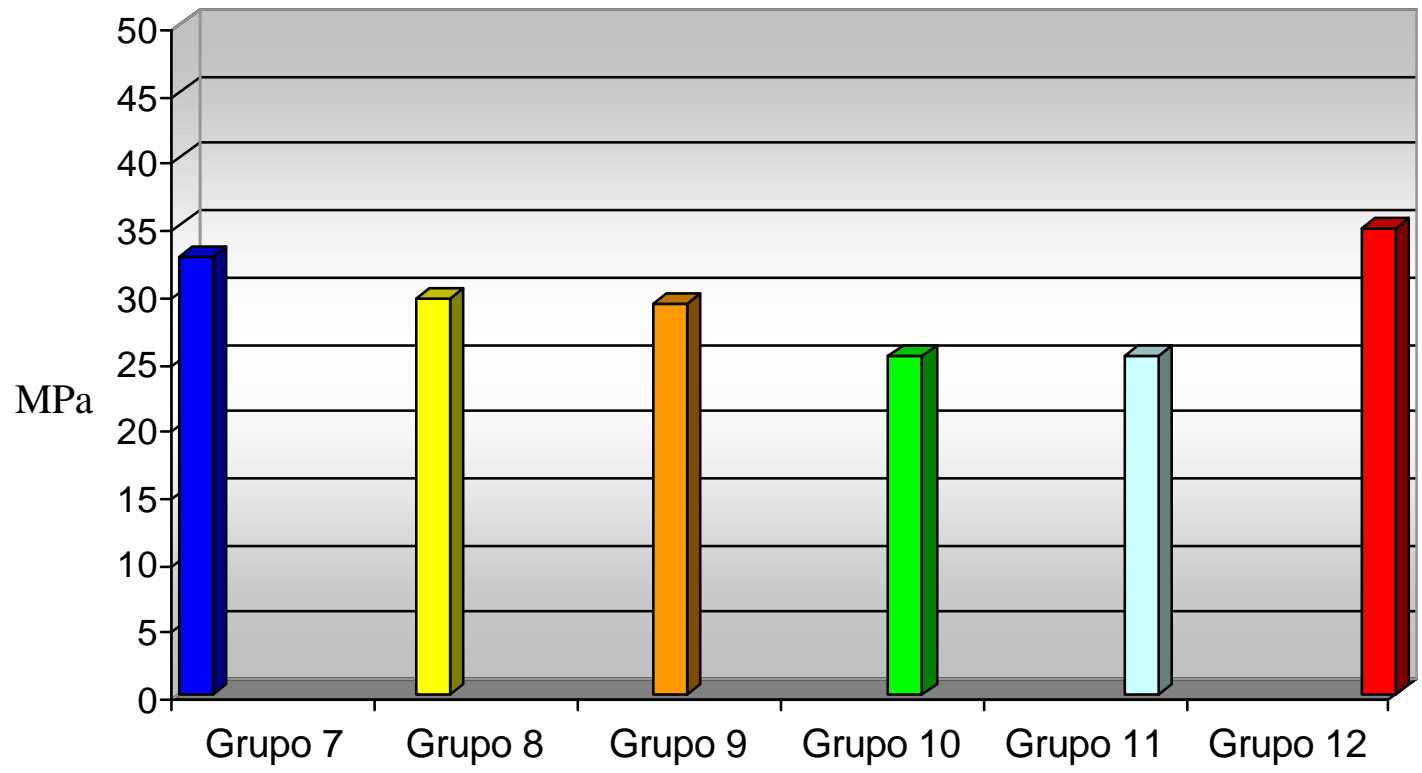

Figura 8 - Gráfico - Média dos valores de resistência adesiva utilizando o sistema adesivo Prime\&Bond NT e a resina composta TPH com os diferentes tratamentos superficiais da dentina.

Após os testes de resistência adesiva, todos os espécimes foram recolhidos para a análise do padrão de fratura, o qual foi dividido em três categorias: A- Fratura adesiva; B- Fratura Mista e C- Fratura coesiva. Os resultados da freqüência de cada tipo de fratura, por grupo, estão descritos nas tabelas 2 e 4 . Foram selecionados, ainda, alguns espécimes para a obtenção de fotomicrografias (Figs. 9,10,11) 


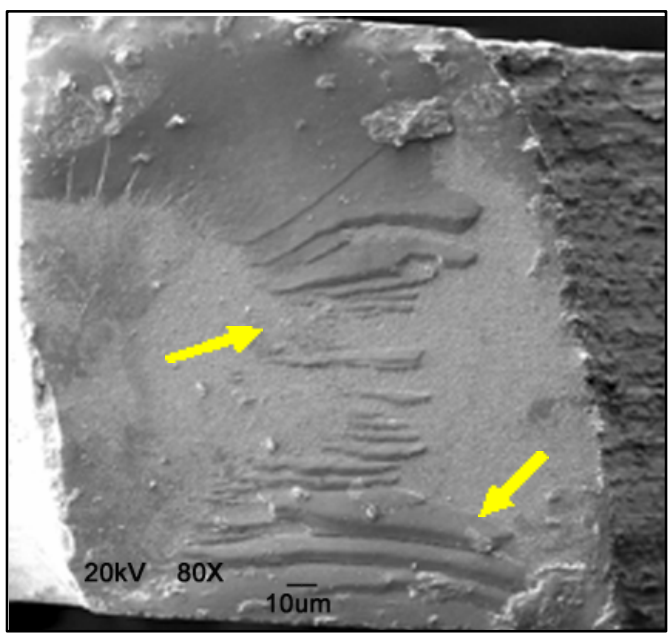

Fig. 9 - Fratura adesiva.

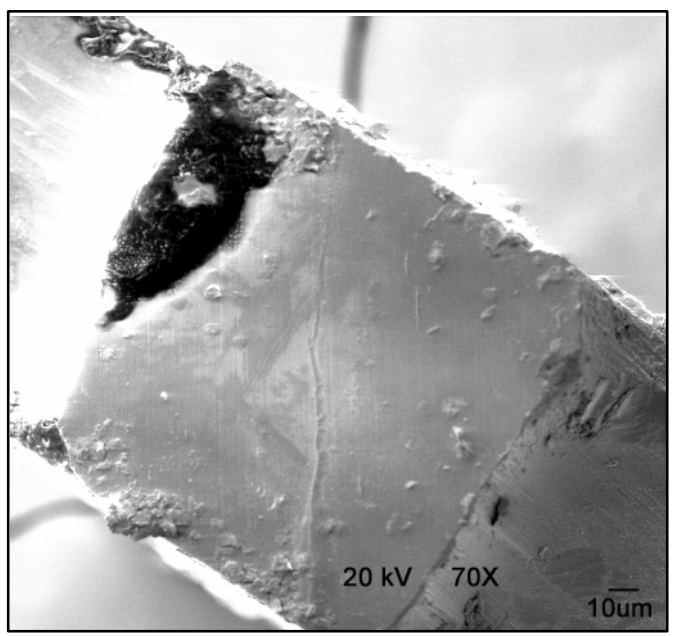

Fig. 10 - Fratura mista. (Setas - adesivo)

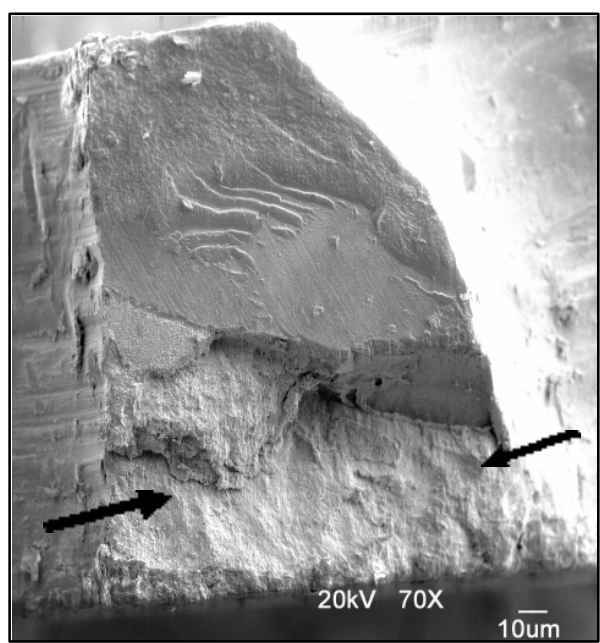

Fig. 11 - Fratura mista (setas- dentina fraturada).

Tabela 3- Tipos de fraturas para os grupos na dent ina.

\begin{tabular}{l|ccc} 
& Fratura Adesiva & Fratura Mista & Fratura Coesiva \\
\cline { 2 - 4 } Grupo 1 & 18 & 02 & 0 \\
Grupo 2 & 14 & 01 & 0 \\
Grupo 3 & 19 & 0 & 0 \\
Grupo 4 & 11 & 0 & 0 \\
Grupo 5 & 12 & 02 & 0 \\
Grupo 6 & --- & --- & --- \\
Grupo 7 & 18 & 0 & 0 \\
Grupo 8 & 14 & 01 & 0 \\
Grupo 9 & 18 & 0 & 0 \\
Grupo 10 & 18 & 0 & 0 \\
Grupo 11 & 20 & 0 & 0 \\
Grupo 12 & 17 & 2 & 0 \\
\hline
\end{tabular}


5.1-B - Resultado dos ensaios de resistência adesiva em esmalte.

No esmalte, nos grupos onde foram utilizados o sistema adesivo Single-Bond (SB) e a resina composta Z-250, o resultado dos valores de resistência adesiva demonstrou que houve diferença estatística significante entre os grupos (Tabela 4). A ordem decrescente dos valores de resistência adesiva foi: Grupo 1: 36,92; Grupo 5: 13,11; Grupo 2: 11,53; Grupo 3: 11,22; e Grupo 4: 10,06 MPa. O grupo condicionado com o ácido fosfórico a 35\%, por 30 segundos, apresentou valores de resistência adesiva significantemente maiores que os demais grupos. Os valores de resistência adesiva dos grupos 2, 3, 4 e 5 não apresentaram diferenças estatísticas significantes entre si. Não foi possível avaliar os valores de resistência do grupo 6 pois todos os espécimes se fraturaram durante os procedimentos de corte.

Tabela 4 - Resultados estatísticos referentes aos grupos onde foram utilizados o sistema adesivo Single-bond e a resina composta Z-250 em associação com os diferentes tratamentos superficiais do esmalte.

\begin{tabular}{|c|c|c|c|}
\hline & $\mathrm{n}$ testados & $\mathrm{n}^{*}$ & Média Resistência adesiva (D.P.) \\
\hline Grupo 1 & 17 & 03 & $36,92^{\mathrm{a}}(11,04)$ \\
\hline Grupo 2 & 17 & 04 & $11,53^{\mathrm{b}}(2,85)$ \\
\hline Grupo 3 & 18 & 07 & $11,22^{b}(3,24)$ \\
\hline Grupo 4 & 16 & 06 & $10,06^{\mathrm{b}}(2,00)$ \\
\hline Grupo 5 & 15 & 05 & $13,11^{\mathrm{b}}(2,71)$ \\
\hline Grupo 6 & -- & -- & ------ \\
\hline
\end{tabular}

n*: n perdidos durante o preparo dos espécimes para os testes de resistência adesiva. 


\begin{tabular}{|ll|}
\hline$\square$ Ác. Fosfórico 35\% 30s & $\square$ Sol. Ác. Bórico 2\% 30s \\
$\square$ Sol. Ác. Bórico 2\% 1 min & $\square$ Gel Ác. Bórico 2\% 30s \\
$\square$ Gel Ác. Bórico $2 \% 1 \mathrm{~min}$ & $\square$ SB sem condicionamento \\
\hline
\end{tabular}

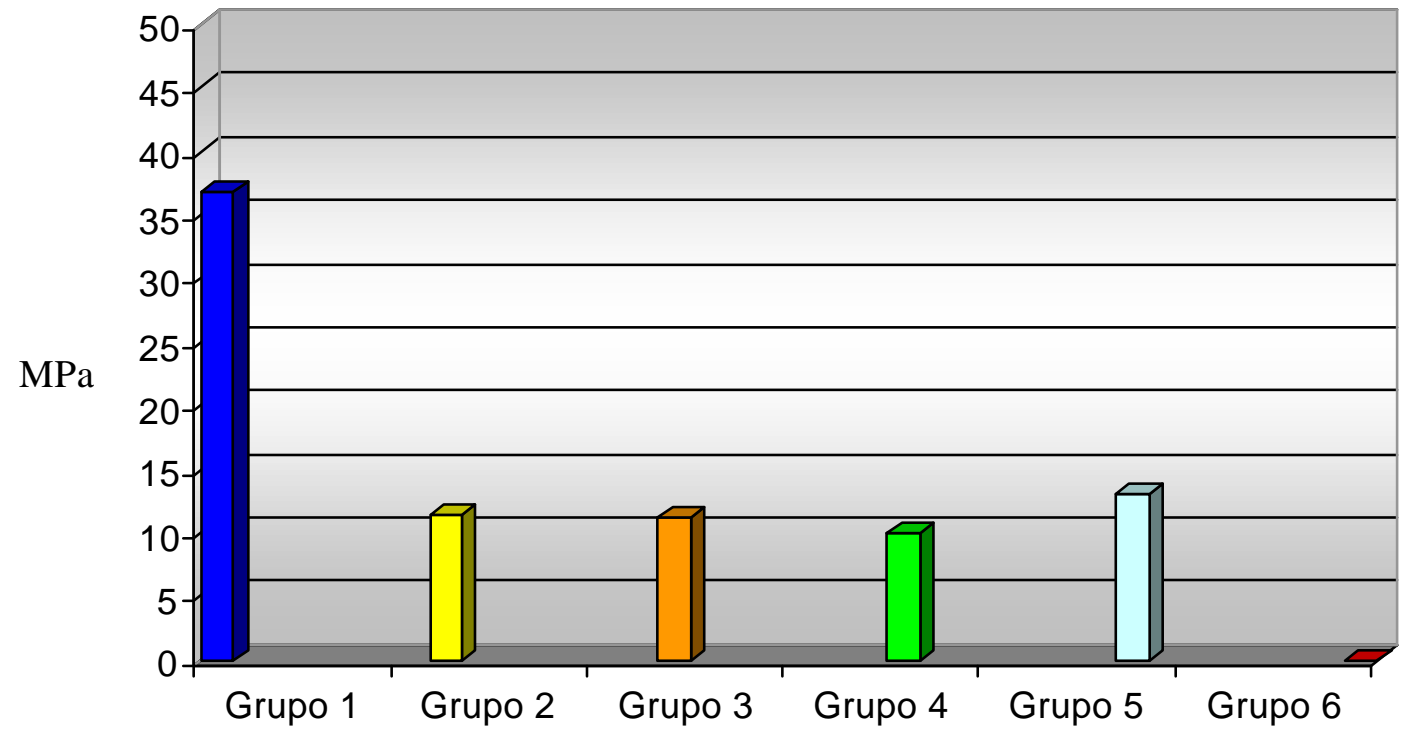

Figura 12 - Gráfico - Média dos valores de resistência adesiva utilizando o sistema adesivo Single-Bond e a resina composta Z-250 com os diferentes tratamentos superficiais do esmalte.

Já os grupos em que se utilizaram o sistema adesivo Prime \& Bond NT (PBNT) e a resina composta (TPH), em associação com os diferentes tratamentos superficiais do esmalte, houve diferença estatística significante nos valores de resistência adesiva entre os grupos (Tabela 5). A ordem decrescente dos valores de resistência adesiva foi: Grupo 7: 42,31 MPa; Grupo 11: 17,40 MPa; Grupo 8: 13,52 MPa; Grupo 9: 13,49 MPa; Grupo 10: 13,16 MPa e Grupo 12: 10,64 MPa. O grupo 7, que recebeu o tratamento superficial do esmalte com o ácido fosfórico a 35\%, por 30 segundos, apresentou valores de resistência adesiva significantemente maiores que os demais grupos. Os valores de resistência adesiva dos grupos 8, 9 e 11 não apresentaram diferenças estatísticas significantes entre si, porém, foram estatisticamente superiores aos do grupo 10 e 12 . Os valores dos grupos 8, 9 e 10 não apresentaram diferenças estatísticas significantes entre si. 
Tabela 5 - Resultados estatísticos referentes aos grupos onde foram utilizados o sistema adesivo Prime \& Bond NT (PBNT) e a resina composta (TPH) em associação com os diferentes tratamentos superficiais do esmalte.

\begin{tabular}{l|c|c|c|}
\multirow{3}{*}{ Grupo 7} & \multicolumn{2}{c}{$\mathrm{n}$ testados } & \multicolumn{2}{c}{$\mathrm{n}^{*}$} & Média Resistência adesiva (D.P.) \\
\cline { 2 - 4 } Grupo 8 & 20 & 05 & $42,31^{\mathrm{a}}(5,41)$ \\
Grupo 9 & 19 & 03 & $13,52^{\mathrm{b}, \mathrm{c}}(4,83)$ \\
\cline { 2 - 4 } Grupo 10 & 23 & 03 & $13,49^{\mathrm{b}, \mathrm{c}}(2,86)$ \\
Grupo 11 & 22 & 02 & $13,16^{\mathrm{c}}(4,09)$ \\
\cline { 2 - 4 } Grupo 12 & 18 & 03 & $17,40^{\mathrm{b}}(4,46)$ \\
\cline { 2 - 4 } & 19 & 03 & $10,64^{\mathrm{c}}(4,41)$
\end{tabular}

n*: $n$ perdidos durante o preparo dos espécimes para os testes de resistência adesiva.

\begin{tabular}{|ll|}
\hline$\square$ Ác. Fosfórico 35\% 30s & $\square$ Sol. Ác. Bórico 2\% 30s \\
$\square$ Sol. Ác. Bórico $2 \% 1 \mathrm{~min}$ & $\square$ Gel Ác. Bórico $2 \% 30 \mathrm{~s}$ \\
$\square$ Gel Ác. Bórico $2 \% 1 \mathrm{~min}$ & $\square$ PBNT sem condicionamento \\
\hline
\end{tabular}

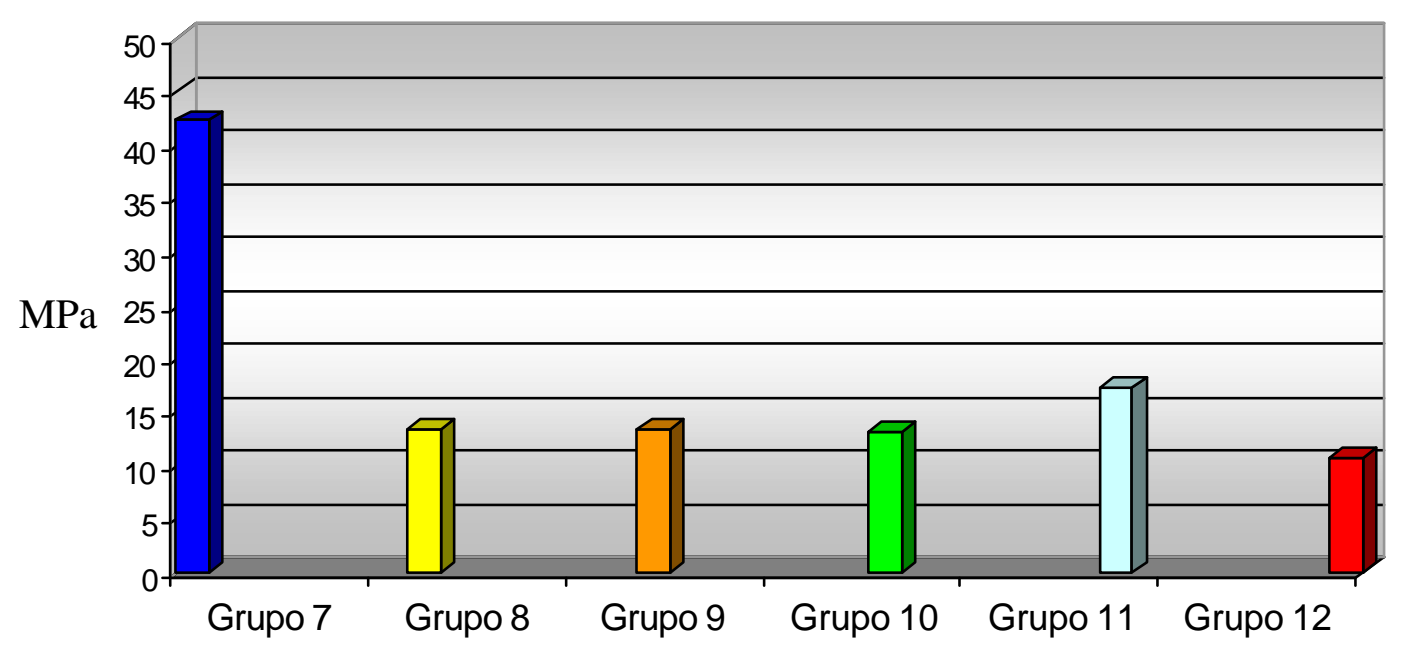

Figura 13 - Gráfico - Média dos valores de resistência adesiva utilizando o sistema adesivo Prime\&Bond NT e a resina composta

TPH com os diferentes tratamentos superficiais do esmalte.

Assim como nos testes na dentina, todos os espécimes foram recolhidos para a análise do padrão de fratura e foram selecionados, ainda, alguns espécimes para a obtenção de fractografias (Figs. 14,15,16) 


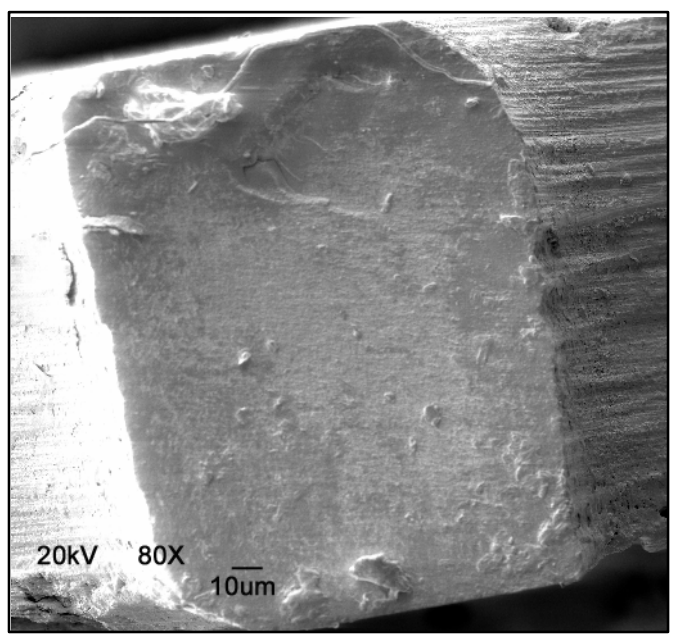

Fig.14 - Fratura adesiva.

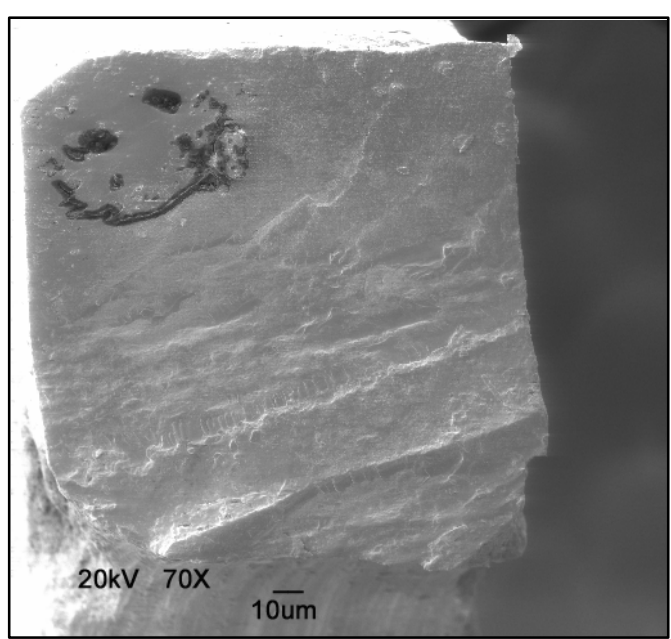

Fig.15 - Fratura mista.

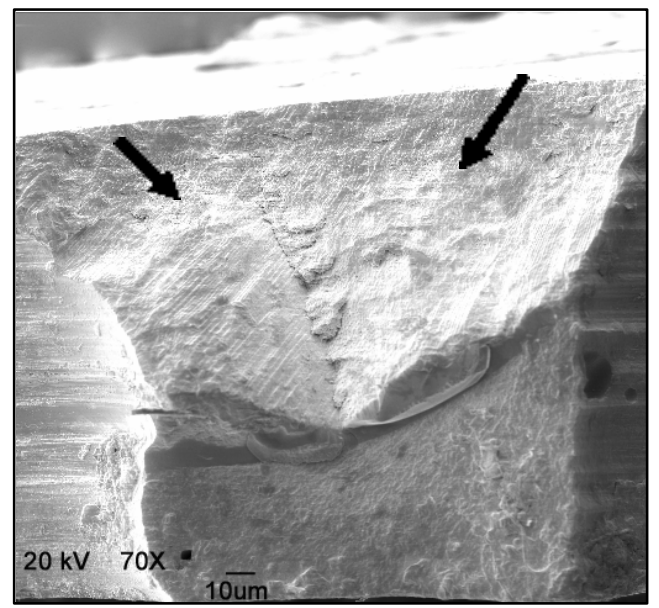

Fig.16 - Fratura mista (setas - esmalte fraturado).

Tabela 6- Tipos de fraturas para os grupos no esmalte.

\begin{tabular}{l|ccc}
\multirow{2}{*}{ Grupo 1 } & Fratura Adesiva & Fratura Mista & Fratura Coesiva \\
\cline { 2 - 4 } Grupo 2 & 17 & 0 & 0 \\
Grupo 3 & 17 & 0 & 0 \\
\hline Grupo 4 & 18 & 0 & 0 \\
Grupo 5 & 15 & 01 & 0 \\
\hline Grupo 6 & 15 & 0 & 0 \\
\hline Grupo 7 & -- & --- & --- \\
\hline Grupo 8 & 16 & 04 & 0 \\
Grupo 9 & 18 & 02 & 0 \\
Grupo 10 & 23 & 0 & 0 \\
Grupo 11 & 21 & 01 & 0 \\
Grupo 12 & 18 & 0 & 0 \\
\hline
\end{tabular}


5. 2 - Resultado do padrão de condicionamento superficial observado no microscópio eletrônico de varredura.

5. 2. A - Resultado do padrão de condicionamento da dentina.

A análise ao microscópio eletrônico de varredura, da superfície dentinária, após os seus diferentes tratamentos, evidenciou aspectos variados. A superfície sem qualquer tratamento apresentou-se coberta totalmente por uma camada de substância amorfa. É possível apenas localizar os túbulos dentinários (setas) sob uma densa camada de agregados (Fig. 17).

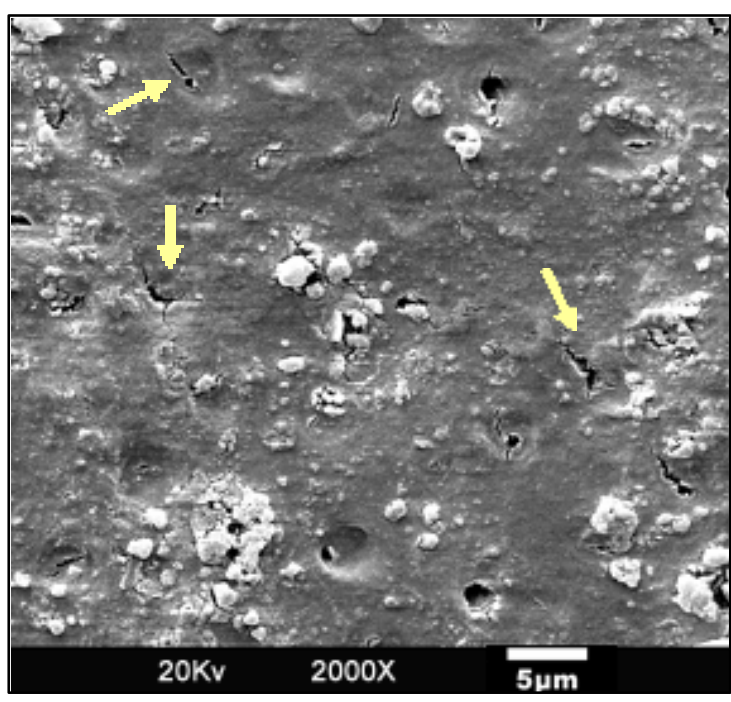

Fig.17 -“Smear layer” padronizada na dentina.

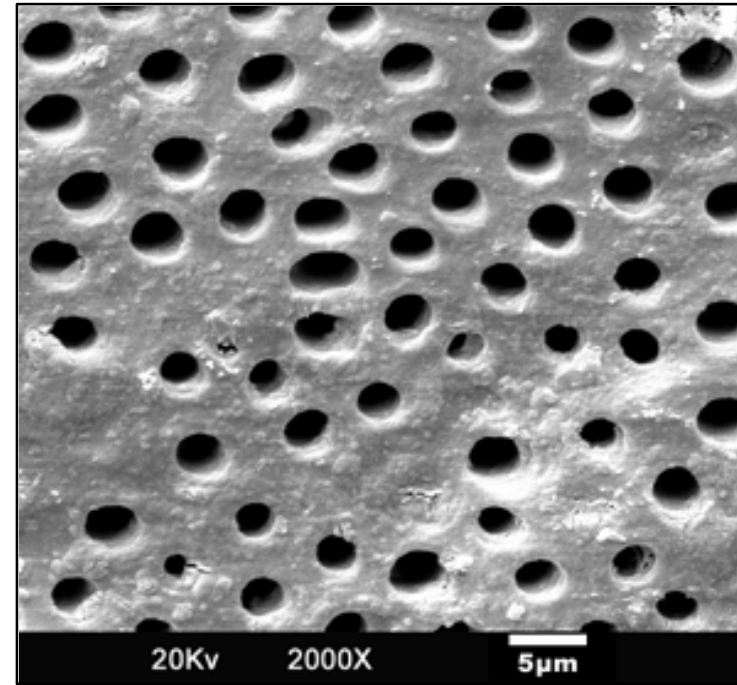

Fig. 18 - Ácido fosfórico a 35\% por 15 segundos na dentina.

A superfície que recebeu o tratamento com o ácido fosfórico a 35\%, por 15 segundos, apresentou-se livre de qualquer substância amorfa. Pode-se observar a presença de túbulos dentinários totalmente desobliterados, remoção completa da "smear 
layer" e dos "smear plugs". Observa-se, também, que a dentina peritubular foi completamente dissolvida pelo condicionamento ácido (Fig 18).

Na superfície que recebeu o tratamento com a solução de ácido bórico a $2 \%$ por 30 segundos, pode-se observar uma leve camada de substância amorfa, túbulos dentinários parcialmente obliterados, evidenciando incompleta remoção da "smear layer" e a presença de "smear plugs" em algumas regiões (Fig 19). A superfície que recebeu o tratamento com a solução de ácido bórico a $2 \%$, por 1 minuto, se caracterizou por apresentar uma maior desmineralização em comparaçào com o tempo de 30 segundos. Pode-se observar uma remoção mais eficaz da "smear layer" com um maior número de túbulos dentinários totalmente desobliterados. Alguns túbulos, entretanto, permanecem total ou parcialmente obstruídos (setas) (Fig 20).

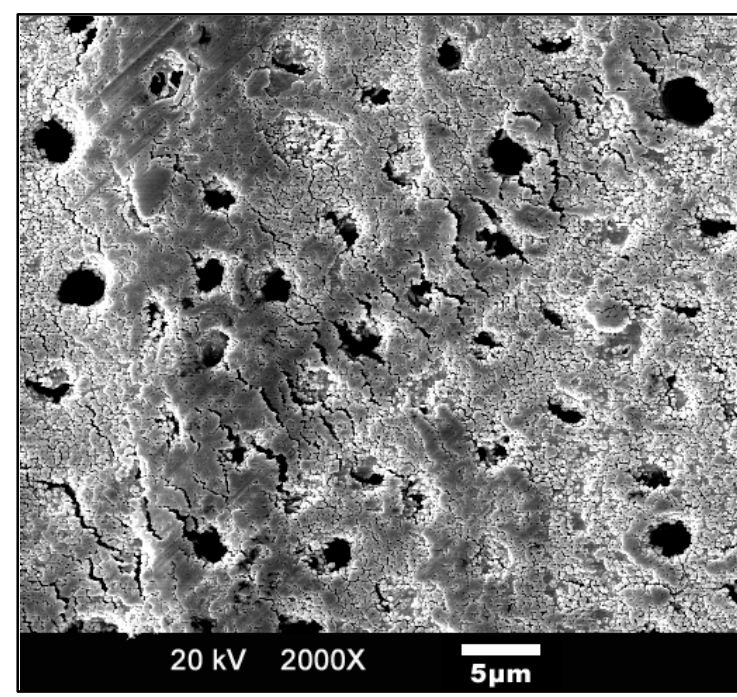

Fig. 19 - Solução de ácido bórico a 2\% por 30 segundos na dentina.

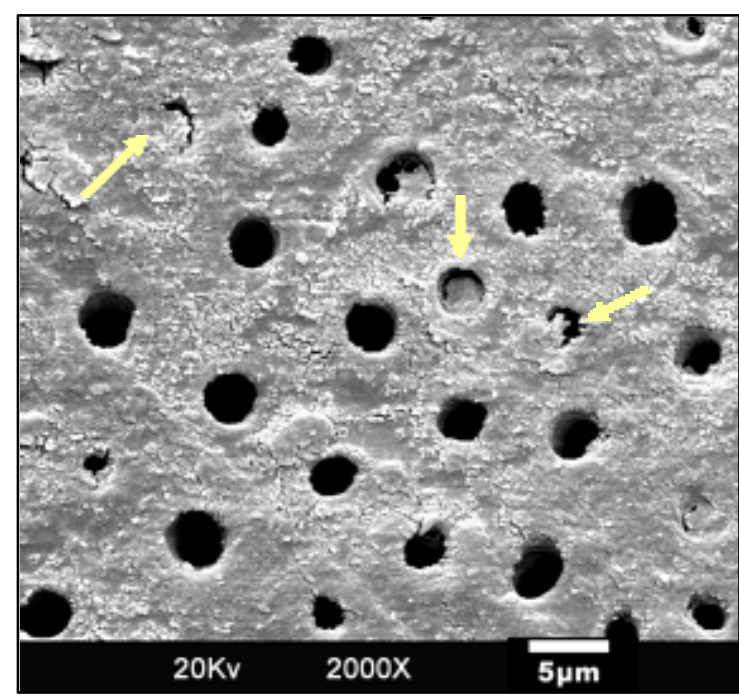

Fig. 20 - Solução de ácido bórico a 2\% por 1 minuto na dentina.

Já quando foi utilizada o ácido bórico a 2\%, por 30 segundos, em forma de gel, pôde-se observar uma camada de substância amorfa sobre a superfície, um grande número de túbulos dentinários parcialmente ou totalmente obliterados, evidenciando 
uma incompleta remoção da "smear layer" e a presença de "smear plugs" na maioria das embocaduras dos túbulos (Fig 21). A figura 22 mostra o condicionamento da superfície em dois planos diferentes, sugerindo que o ácido bórico não reagiu de forma padronizada. Possivelmente, na região centro-esquerda da figura (setas), o contato com a superfície da dentina não se tenha dado pelo tempo completo de 1 minuto devido à consistência do gel. Observa-se, ainda, em ambos os espécimes, o acúmulo de partículas na superfície da dentina, possivelmente produtos da reação do ácido com a "smear layer" não removidos completamente com a lavagem do agente condicionador.

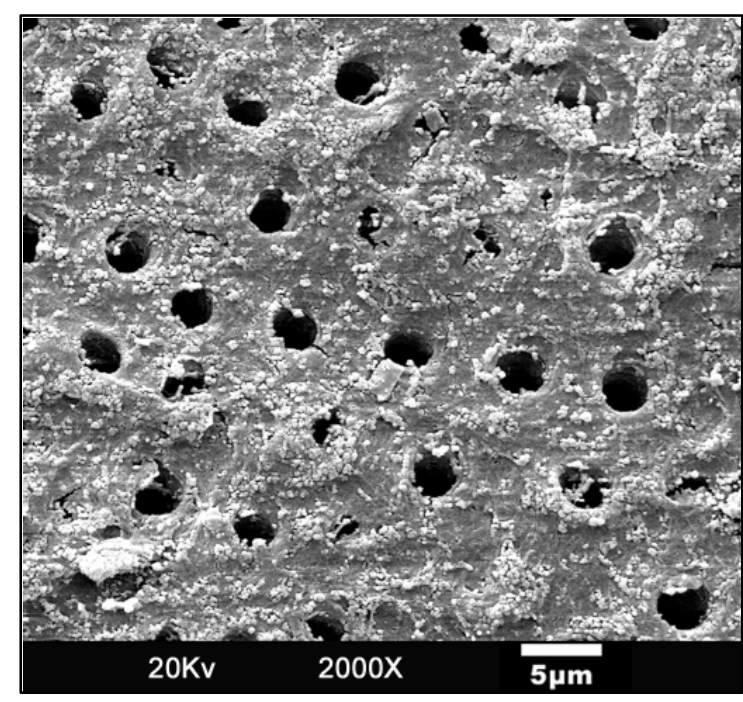

Fig. 21- Gel de ácido bórico a 2\%, por 30 segundos, na dentina

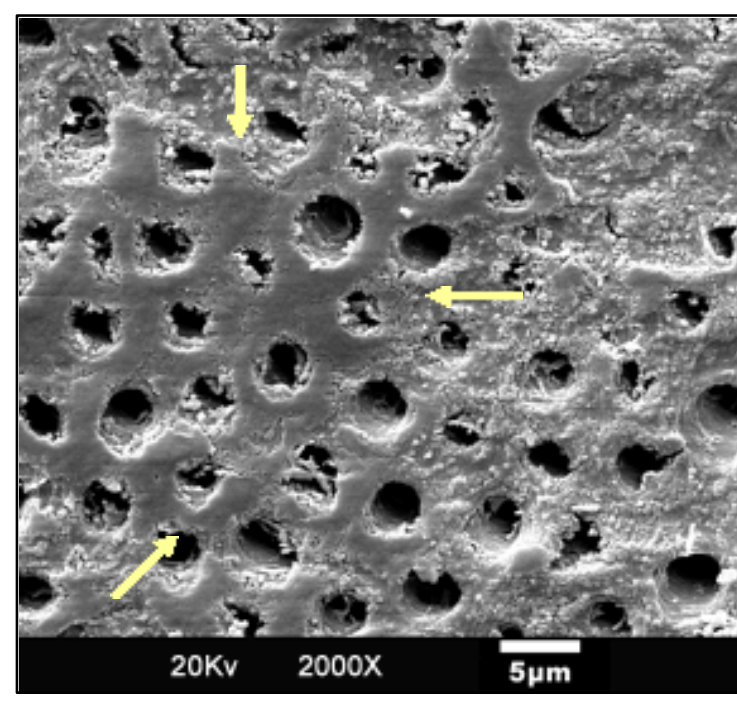

Fig. 22- Gel de ácido bórico a 2\%, por 1 minuto, na dentina

Nos espécimes tratados apenas com o Prime\&Bond NT, por 30 segundos, a superfície dentinária se apresentou quase que totalmente livre de substância amorfa. Em apenas algumas regiões, os túbulos continham, ainda, restos de "smear plugs" (Fig. 23setas). O padrão de condicionamento dentinário apresentado por esse adesivo assemelha-se àquele proporcionado pelo ácido fosfórico a 35\%, por 15 segundos, e mais expressivo que o apresentado pelo ácido bórico a 2\%, na apresentação líquida, por 1 minuto. Entretanto, quando somente o sistema adesivo Single-Bond foi aplicado, pode- 
se observar apenas a remoção parcial da "smear layer", permanecendo a obstrução tubular (Fig. 24). Assim, os agentes condicionadores podem ser listados de acordo com sua efetividade de remoção da "smear layer", em ordem decrescente, como segue: ácido fosfórico a 35\%, por 15 segundos; Prime\&Bond NT por 30 segundos, ácido bórico a 2\% (líquido) por 1 minuto; ácido bórico a 2\% (gel) por 30 segundos; ácido bórico a 2\% (gel) por 1 minuto; ácido bórico a 2\% (líquido) por 30 segundos e Single-Bond por 30 segundos.

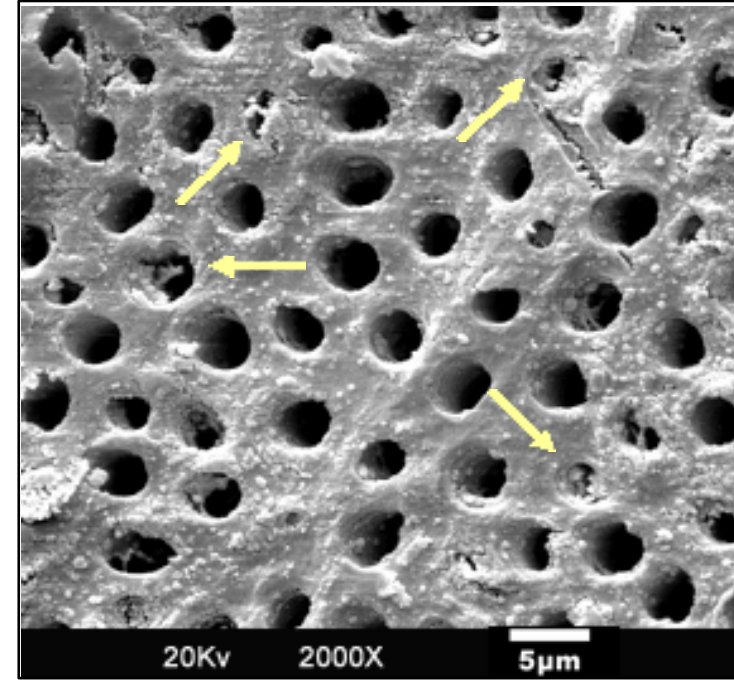

Fig. 23 - Sistema adesivo Prime\&Bond NT na dentina.

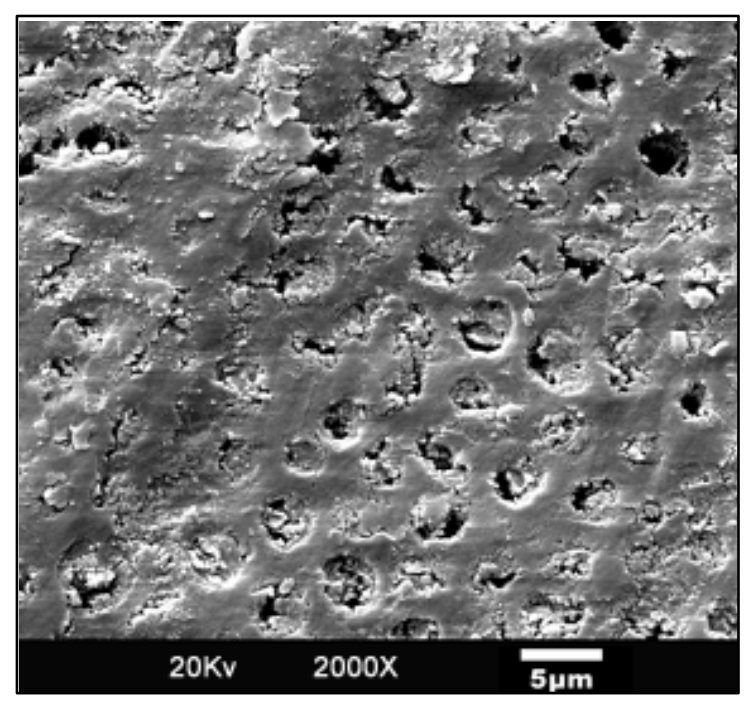

Fig. 24 - Sistema adesivo Single-Bond na dentina.

5. 2 - B. Resultado do padrão de condicionamento do esmalte.

Assim como na dentina, a análise ao microscópio eletrônico de varredura, da superfície do esmalte, após os seus diferentes tratamentos, também evidenciou diferentes aspectos superficia is relacionados com cada tipo de agente condicionador. A superfície que foi lixada e ficou isenta de tratamento com soluções ácidas apresentou-se coberta totalmente por uma camada de substância amorfa. Não é possível localizar os prismas de esmalte sob a densa camada de agregados, notando-se claramente a presença 
da "smear layer" recobrindo a superfície e obliterando totalmente os prismas de esmalte (Fig. 25). Por outro lado, a superfície que foi condicionada com o ácido fosfórico a 35\%, por 30 segundos, apresentou completa remoção da camada de substância amorfa, evidenciando claramente os prismas de esmalte. Pode-se observar um padrão tipo 2 de condicionamento de acordo com SILVERSTONE et al. ${ }^{99}$, em 1975, que se caracteriza por uma maior desmineralização da periferia dos prismas em relação à parte central dos mesmos (Fig.26).

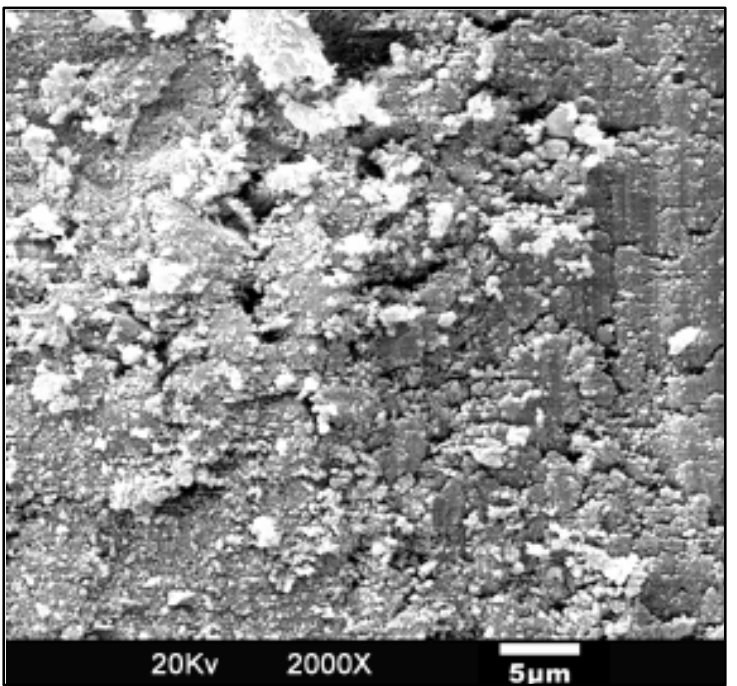

Fig. 25 - "Smear layer" padronizada no esmalte.

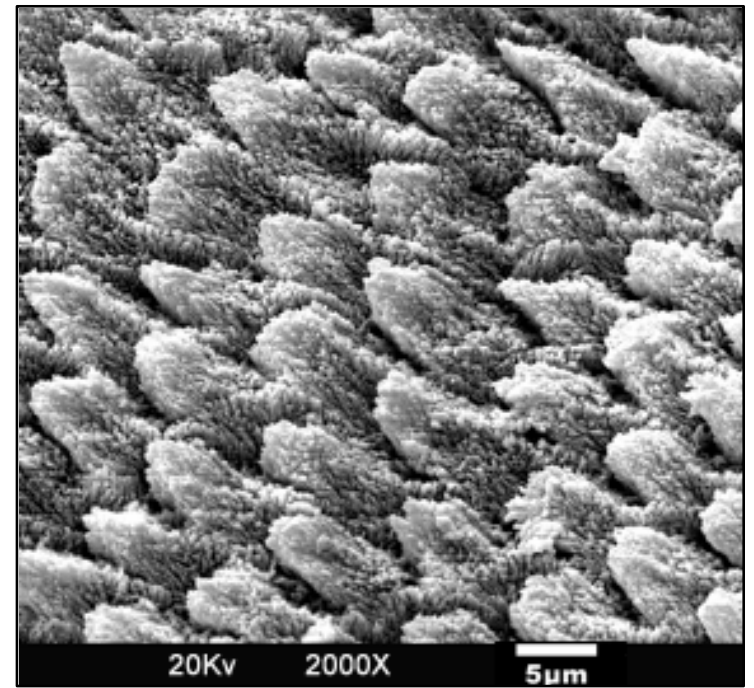

Fig. 26 - Ácido fosfórico a 35\%, por 30 segundos, no esmalte.

Na superfície que recebeu o tratamento com a solução de ácido bórico a 2\%, por 30 segundos, pode-se verificar a remoção parcial da substância amorfa. Esse tratamento permite distinguir os prismas de esmalte individualmente, mas sua microestrutura permanece selada por resíduos da incompleta desmineralização (Fig.27). Entretanto, quando tratado com a mesma solução, por 1 minuto (Fig. 30), o padrão de desmineralização assemelha-se àquele proporcionado pelo ácido fosfórico a 35\%, por 
30 segundos, exceto pela menor profundidade de desmineralização. Pode-se observar maior desmineralização da periferia dos prismas em relação à parte central dos mesmos, caracterizando o padrão tipo 2 de condicionamento já mencionado.

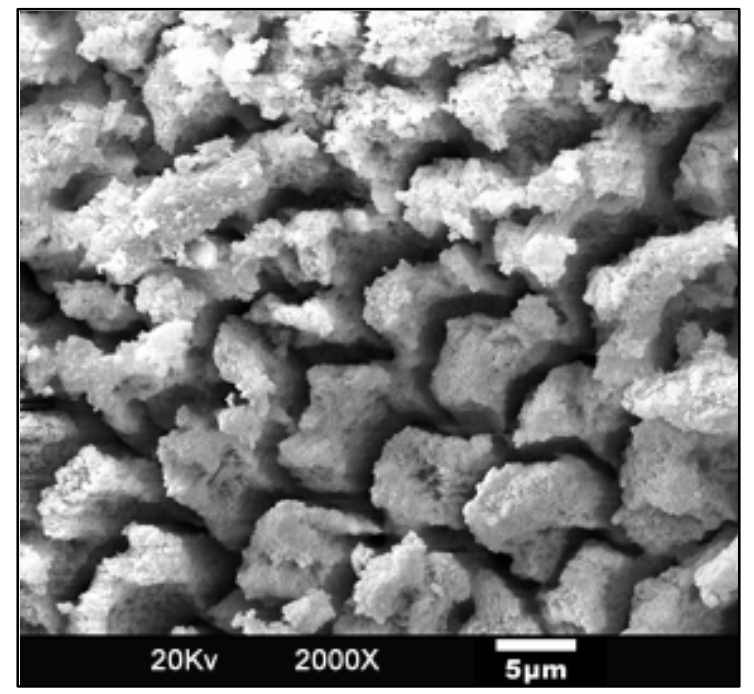

Fig. 27 - Solução de ácido bórico a $2 \%$ por 30 segundos no esmalte.

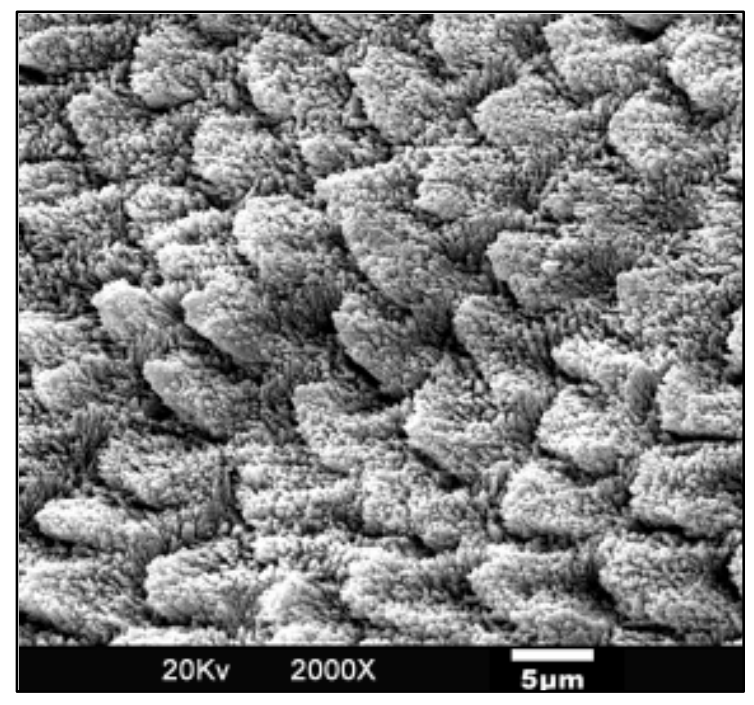

Fig. 28 - Solução de ácido bórico a 2\% por 1 minuto no esmalte.

Nos espécimes que receberam o tratamento com o gel de ácido bórico a 2\%, por 30 segundos, observa-se uma camada de substância amorfa sobre a superfície do esmalte. Não é possível localizar os prismas de esmalte sob a densa camada de agregados. Nota-se, apenas, um pequeno grau de desmineralização sem, no entanto, definir as características do esmalte condicionado (Fig. 29). O gel de ácido bórico a 2\%, aplicado por 1 minuto, apresentou também um pequeno poder de desmineralização. Ocorreu incompleta remoção da "smear layer", evidenciando uma exposição parcial e irregular dos prismas de esmalte (Fig. 30). Observa-se nos espécimes desse grupo 
fenômeno semelhante ao observado nas superfícies de dentina, isto é, a alternância entre áreas de significativa desmineralização e outras onde esse efeito é menor (Fig. 30 setas). Tal padrão sugere um contato irregular do gel desmineralizador com a superfície do esmalte.

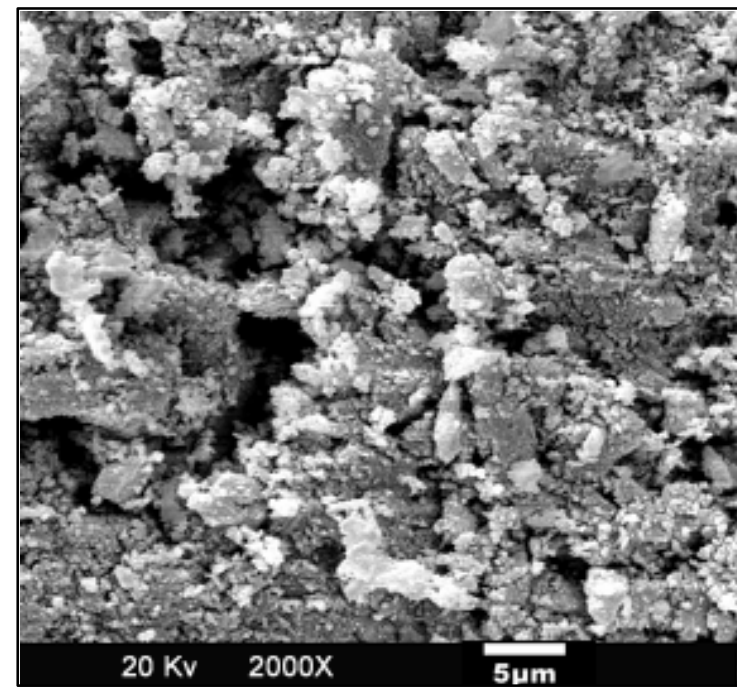

Fig. 29- Gel de ácido bórico a $2 \%$, por 30 segundos, no esmalte

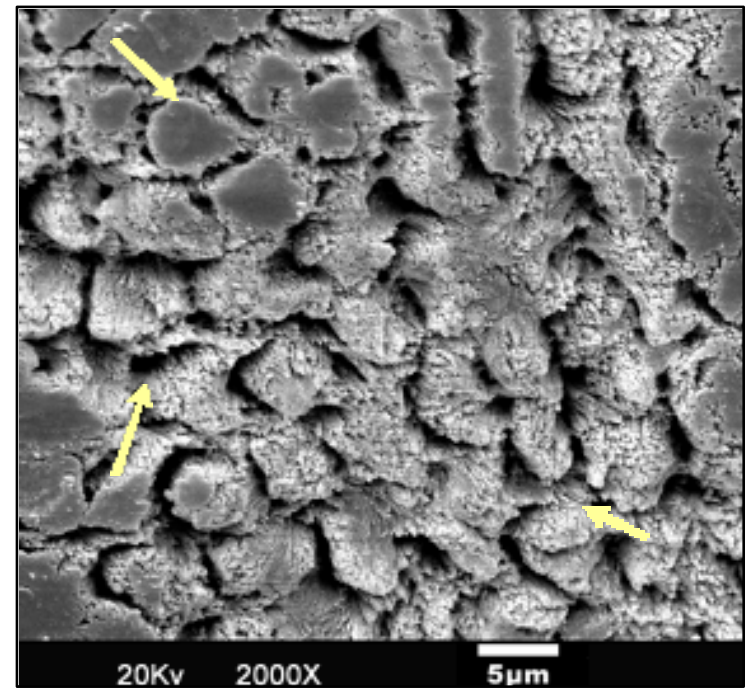

Fig. 30- Gel de ácido bórico a 2\%, por 1 minuto, no esmalte

Nas superfícies onde foram aplicados os sistemas adesivos Prime \& Bond NT e Single-Bond, pode-se observar uma área quase que totalmente coberta por uma camada de substância amorfa (Fig. 31,32). Não é possível a visualização dos prismas de esmalte, mas apenas o perfil dos mesmos, principalmente nos espécimes tratados com Prime\&Bond NT (Fig. 31). A microestrutura do esmalte permanece obscurecida pela presença da "smear layer". 


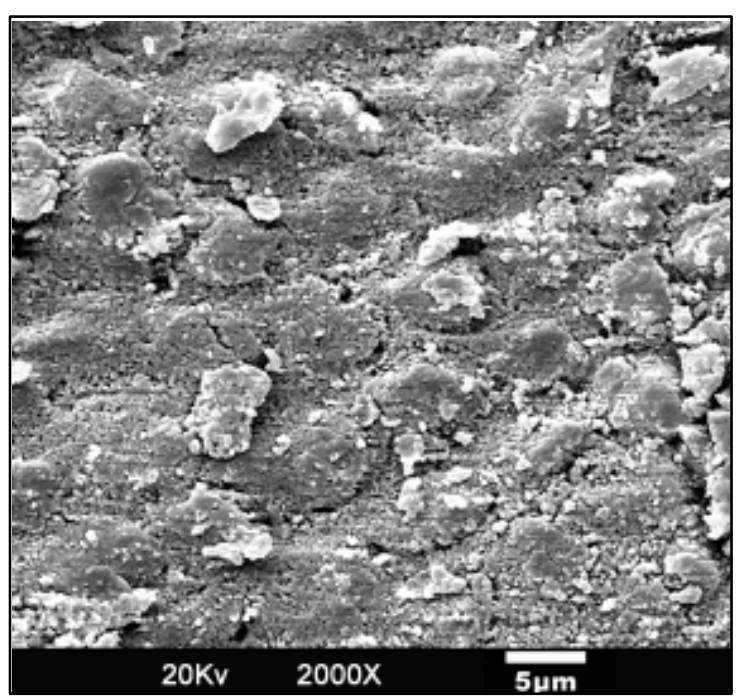

Fig. 31 - Sistema adesivo Prime\&Bond NT no esmalte.

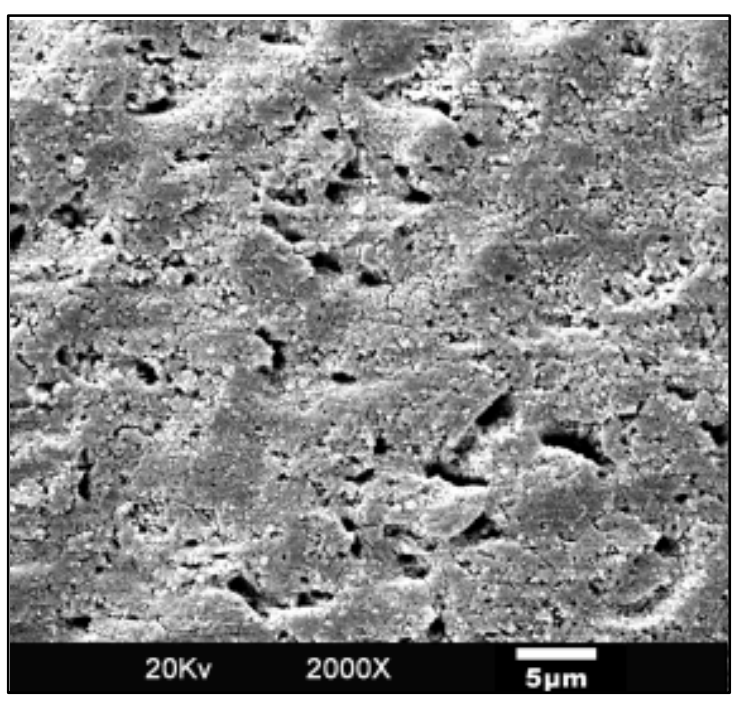

Fig. 32 - Sistema adesivo Single-Bond no esmalte. 
6. DISCUSSÃO 


\section{6- DISCUSSÃO.}

\section{1- Da metodologia.}

O trabalho testou a hipótese de que o ácido bórico a $2 \%$ poderia proporcionar substratos dentinário e de esmalte com características suficientes para se obter uma resistência adesiva semelhante à conseguida após condicionamento com ácido fosfórico a 35\%. Para que fossem mensurados os valores de resistência adesiva, de acordo com os diferentes materiais utilizados, foram realizados testes de microtração tanto na dentina como no esmalte. Foi realizado, ainda, um estudo do padrão de condicionamento superficial pela análise no microscópio eletrônico de varredura, objetivando a realizar uma correlação entre os valores de resistência adesiva e as imagens observadas.

Para isso, foi utilizado, para o grupo controle, o ácido fosfórico a 35\% para o condicionamento do esmalte e da dentina por se conhecer a sua capacidade de fornecer substratos com características suficientes para se conseguir altos valores adesivos $1,10,31,65,66,67,68,75,76,80,92,106$.

$\mathrm{O}$ ácido fosfórico ou ácido orthofosfórico $\left(\mathrm{H}_{3} \mathrm{PO}_{4}\right)$ pode-se apresentar em forma de cristais sólidos ou em líquido incolor e sem odor. Seu ponto de fusão é em torno de $21^{\circ} \mathrm{C}$, e ponto de ebulição em torno de $158^{\circ} \mathrm{C}$. É um ácido estável, incompatível com pós metálicos, bases fortes e compostos contendo aço. O ácido é corrosivo, causa queimaduras e pode causar danos se em contato com a pele. É muito destrutivo se entrar em contato com membranas mucosas, trato respiratório olhos e pele. A dose letal em ratos é de $1530 \mathrm{mg} \mathrm{Kg}^{-1} \mathrm{e}$, nos homens, $200 \mathrm{mg} \mathrm{Kg}^{-1}$. O manuseio do ácido deve ser 
com óculos de proteção em locais de boa ventilação e com luvas plásticas ou de borracha.

A utilização do ácido bórico fundamentourse nos trabalhos de PEREIRA e CASTRO $^{81}$ (1998), CASTRO ${ }^{23}$ (2000), que verificaram o padrão de condicionamento dentinário desse ácido na concentração de $2 \%$ em solução e em forma de gel. O autor utilizou tempos de 15 segundos, 30 segundos e 1 minuto e verificou que nos tempos de 30 e 60 segundos a desmineralização foi semelhante à conseguida com ácido fosfórico a $37 \%$ por 15 segundos, porém com a presença de "smear plugs" nos túbulos dentinários. Assim, o autor especulou sobre a possibilidade da utilização do ácido bórico a 2\% como agente condicionador antes da aplicação de sistemas adesivos. A suposta vantagem da utilização do ácido bórico seria a de se consequir uma resistência adesiva semelhante à conseguida após condicionamento com ácido fosfórico a 35\%, em uma superfície dentinária com a exposição das fibras colágenas e com a manutenção dos "smear plugs" no interior dos túbulos dentinários, ou seja, em uma superfície menos permeável.

$\mathrm{O}$ ácido bórico $\left(\mathrm{H}_{3} \mathrm{BO}_{3}\right)$ apresenta alguns sinônimos como ácido borácico, ácido orthoborico, borafax, hidróxido orthoborato. Apresenta-se como um sólido cristalino, incolor ou branco e sem odor. Como propriedades químicas apresenta o ponto de fusão em torno de $171^{\circ} \mathrm{C}$, ponto de ebulição em $171^{\circ} \mathrm{C}$, solubilidade em água a $63,5 \mathrm{~g} / \mathrm{l}$ a $30^{\circ}$ C e gravidade específica em torno de 1,44. É um ácido estável, não inflamável, reage violentamente com o potássio e anidridos ácidos. É incompatível com água, bases fortes e metais alcalinos e sensível à umidade. Essa imcompatibilidade com tais substâncias nos leva a especular sobre uma possível compatibilidade com os adesivos atuais que apresentam características acídicas. $\mathrm{O}$ ácido bórico pode ser danoso à saúde bem como 
irritante se inalado. A dose letal para ratos é de $2660 \mathrm{mg} \mathrm{Kg}^{-1}$ e, para o homem, é de 429 $\mathrm{mg} \mathrm{Kg}{ }^{-1}$. Para a manipulação desse ácido, é recomendada a utilização de óculos de proteção em locais de boa ventilação. O mesmo possui propriedades antissépticas ${ }^{6,114} \mathrm{e}$ é freqüentemente utilizado na forma de supositórios inseridos na vagina para o tratamento de infecções vaginais ${ }^{49}$. Porém, contrindica-se o uso desse ácido durante a gravidez e em lesões abertas que permitam a entrada do ácido no organismo. Quando no interior do organismo, o ácido pode causar náuseas, vômitos, diarréia, dermatites, falhas no sistema circulatório, taquicardia, convulsões e coma. Um indivíduo adulto pode falecer se ingerir cerca de 5 a $20 \mathrm{~g}$ do ácido e, em crianças, a ingestão de quantidades inferiores a $5 \mathrm{~g}$ pode ser letal ${ }^{60}$. Além das propriedades antissépticas, o ácido bórico possui propriedade antiviral. A aplicação tópica do ácido diluído em forma de borato de sódio tem efeito curativo em lesões herpéticas labiais ${ }^{100}$. O ácido bórico é utilizado, ainda, para impermeabilização de madeiras, em preservativos, cimentos industriais, porcelanas, vidros, boratos, carpetes, sabonetes, cosméticos, impressões e em inseticidas para baratas e besouros pretos de carpetes ${ }^{60}$.

A utilização desta solução de ácido bórico a $2 \%$, no esmalte, se justifica pela possibilidade de se utilizar a mesma solução ácida para o condicionamento da dentina e do esmalte. Não há informações, na literatura, sobre o emprego do ácido bórico como condicionador do esmalte, exceto pelo trabalho de FRANCISCHONE et al. ${ }^{34}$, em 1984.

Os sistemas adesivos utilizados foram o Single-Bond (3M) e o Prime \& Bond NT (Dentsply) por serem dois sistemas que necessitam de um condicionamento ácido prévio e por serem atualmente muito utilizados nos trabalhos que avaliam valores de resistência adesiva $1,10,31,65,66,67,68,75,76,92,106$. As resinas compostas Z-250 (3M) e TPH 
Spectrum (Dentsply) foram eleitas com o objetivo de utilizar o conjunto sistema adesivo/resina composta de um mesmo fabricante evitando-se, assim, a incorporação de outras variáveis no trabalho.

Até 1994, os trabalhos que avaliavam a resistência adesiva dos materiais utilizavam como metodologia os testes de resistência à tração e resistência ao cisalhamento. Nos testes de resistência às cargas de cisalhamento, a união adesiva é rompida através da aplicação de uma força paralela à interface adesiva ${ }^{36,69}$. Apesar de serem largamente utilizados, os testes de cisalhamento são altamente criticados por se acreditar que a distribuição dos estresses na interface substrato dentário/material adesivo não é uniforme ${ }^{103,115,113}$. Assim, a fratura se inicia no ponto onde a força é aplicada e não, necessariamente, na interface adesiva ${ }^{12}$. CARDOSO; BRAGA; CARRILHO ${ }^{21}$, em 1998, preconizam a utilização dos testes de cisalhamento para se mensurar a resistência de materiais e não a resistência de interfaces adesivas.

Os testes de tração são realizados através da aplicação de forças perpendiculares à interface adesiva ${ }^{36,69}$. Esse tipo de teste também é muito realizado, porém, atualmente, muito criticado. A mais severa crítica aos testes de tração é a dificuldade em se conseguir manter um correto alinhamento da superfície adesiva em relação ao eixo de tração. Esse procedimento é necessário para se evitar uma má distribuição de estresses ao longo da interface adesiva ${ }^{69,103}$. SANO et al. ${ }^{93}$, em 1994, observam que os testes de tração apresentam altas frequiências de fraturas coesivas na dentina. Os autores salientam que, utilizando-se grandes áreas adesivas, alguns sistemas adesivos apresentam fraturas coesivas em dentina com resistências adesivas próximas a $5 \mathrm{MPa}$. Ou seja, fraturas dentinárias apresentando valores de resistência bem menores que a 
resistência intrínseca da dentina, reportada na literatura, que varia de 52 a $104 \mathrm{MPa}{ }^{94}$. Esses resultados se devem, segundo os autores, a uma distribuição não uniforme dos estresses ao longo da interface adesiva bem como defeitos intrínsecos do substrato.

Ainda sobre as características dos tradicionais testes que avaliam a resistência adesiva (testes de cisalhamento e de tração), PASHLEY et al. ${ }^{74}$, em 1999, observam que estes podem ser realizados para se mensurarem resistências adesivas relativamente baixas (10 a $15 \mathrm{MPa})$. Porém, quando os valores de resistência excedem os descritos acima, freqüentemente acontecem falhas coesivas no substrato dentinário. A freqüência dessas falhas coesivas pode chegar a $80 \%$ quando esses testes são utilizados com materiais que apresentam resistências adesivas próximas a $25 \mathrm{MPa}$. Assim, a interface adesiva permanece intacta, o que impede o conhecimento do verdadeiro valor adesivo interfacial. Essas falhas adesivas não, necessariamente, significam que a interface dente/ material adesivo é uniformemente mais forte que a resistência intrínseca da dentina, mas, sim, que houve uma distribuição não uniforme do estresse localizado em uma região que deu início ao processo de fratura interna da dentina.

Como alternativa aos testes tradicionais, SANO et al. ${ }^{93}$ e CARVALHO et al. ${ }^{22}$, em 1994, desenvolveram um novo tipo de teste com o objetivo de fornecer uma melhor distribuição de estresses ao longo da interface evitando-se, assim, fraturas coesivas no corpo da dentina. Teste esse denominado de microtração. Testando a hipótese de que não há relação entre a área da superfície adesiva e a resistência adesiva à dentina, os autores utilizaram corpos de prova com diferentes áreas adesivas de diferentes dimensões. Após a realização dos testes de tração, os resultados demonstraram que os valores de resistência adesiva foram inversamente proporcionais à área adesiva. Esse 
novo método de microtração permitiu medir altos valores de resistência adesiva sem falhas coesivas, em dentina, além de possibilitar a realização de múltiplas medidas num mesmo dente.

Em adição às vantagens observadas por SANO et al. ${ }^{93}$ e CARVALHO et al. ${ }^{22}$, do teste de microtração, PASHLEY et al. ${ }^{74}$, em 1999, citam a prevalência de fraturas na interface adesiva em detrimento da acorrência de falhas coesivas em dentina, a obtenção de múltiplos espécimes através de um único dente, a possibilidade de que sejam mensurados altos valores de resistência adesiva, a capacidade do teste avaliar diferenças regionais de resistência adesiva, a possibilidade de as médias e as variações poderem ser medidas em um único dente, testes de uniões adesivas em superfícies irregulares, a capacidade de medição de pequenas áreas adesivas e a facilidade no exame as falhas adesivas no microscópio eletrônico de varredura devido à pequena dimensão do espécime. Os autores citam como desvantagem do teste de microtração a dificuldade em se mensurar valores de união menores que $5 \mathrm{MPa}$, a necessidade em se adquirir equipamentos especiais, a complexidade técnica laboratorial do teste e a possibilidade dos pequenos espécimes desidratarem rapidamente.

Após a realização de um cuidadoso estudo laboratorial, que culmina com a obtenção de valores adesivos interfaciais, contra-indica-se uma associação direta desses resultados com um possível comportamento clínico do material. Apesar dos vários tipos de testes laboratoriais utilizados, nenhum reproduz com exatidão as complexas forças exercidas clinicamente em uma restauração ou no próprio dente. A rigor, valores de resistência adesiva obtidos em testes laboratoriais devem objetivar, primeiramente, a 
obtenção de melhorias nas propriedades dos materiais e, em seguida, para se especular sobre um possível comportamento clínico desse material ${ }^{88,103,113}$. 


\section{2 - Dos resultados.}

\section{2. A - Ensaios de resistência adesiva em dentina.}

O processo adesivo ao substrato dentinário se fundamenta, atualmente, na remoção parcial ou total da "smear layer" através da aplicação de uma solução ácida que desmineraliza a dentina abrindo a embocadura dos túbulos dentinários e expondo a trama de fibras colágenas. Em sequida, é aplicada uma solução composta por monômeros hidrofílicos resinosos diluídos em solventes (acetona, água, etanol). Esses monômeros se difundem por entre as fibras colágenas expostas, formando uma camada denominada de camada híbrida ${ }^{64}$ que, após a polimerização da resina, é a grande responsável pela resistência adesiva dos materiais à dentina ${ }^{1,31,65}$.

Conhecendo-se o processo adesivo descrito acima, foram utilizadas diferentes soluções ácidas, em associação com um mesmo sistema adesivo, com o objetivo de se avaliar a interferência de cada tipo de solução ácida nos valores de resistência adesiva fornecidos pelos sistemas adesivos.

Quando se utilizou o sistema adesivo Single-Bond, em associação com as diferentes soluções ácidas, os valores das médias de resistência adesivas dos diferentes grupos apresentaram diferenças estatísticas significantes. O grupo 1 apresentou valores significantemente maiores do que os demais $(41,88 ; 15,05 ; 16,10 ; 5,93$ e 10,59 MPa, respectivamente para cada grupo). 
Em adição, o estudo do padrão de condicionamento dentinário das diferentes soluções ácidas revelou que o ácido fosfórico a 35\%, por 15 segundos, apresentou maior poder desmineralizante (Fig. 18) comparado com todas as formulações de ácido bórico. (Fig 19,20,21,22).

Na superfície que recebeu o tratamento com o ácido fosfórico a 35\%, por 15 segundos, pode-se observar a presença de túbulos dentinários totalmente desobliterados, remoção completa da "smear layer" com ausência de "smear plugs" e dentina peritubular e intratubular bem definidas. Essas características morfológicas também foram observadas nos trabalhos de JACOBSEN et al. ${ }^{51}$, em 2000, TEBECHRANI; MUENCH; JÚNIOR ${ }^{107}$, em 2000, e PIOCH et al. ${ }^{84}$, em 1998, e são responsáveis pelos altos valores de resistência de união obtidos quando da utilização desse tipo de ácido na dentina, por 15 segundos, em associação com o sistema adesivo Single-Bond (PAUL et al. $^{75}$, em 1999, 40,0 MPa; PERDIGÃO et al. ${ }^{76}$, em 2001, 45,4 MPa; OGATA et al. ${ }^{68}$, em 2001, 44,5 MPa; NAKAJIMA et al. ${ }^{65}$, em 2000, 49,9 MPa; NAKAJIMA et al. ${ }^{66}$, em 2002, 34,3 MPa; NUNES; SWIFT, Jr.; PERDIGÃO ${ }^{67}$, em 2001, 75,9 MPa e TERADA $^{108}$, em 2001, 51,6 MPa). O valor para o ácido fosfórico neste trabalho (40,92 MPa) é semelhante aos obtidos por PAUL et al. ${ }^{75}$, em 1999, (40,0 MPa); PERDIGÃO et al. ${ }^{76}$, em 2001, (45,4 MPa); OGATA et al. ${ }^{68}$, em 2001, (44,5 MPa); NAKAJIMA et al. ${ }^{5}$, em 2000, (49,9 MPa); e inferior aos obtidos por NUNES; SWIFT, Jr.; PERDIGÃO ${ }^{67}$, em 2001, (75,9 MPa) e TERADA ${ }^{108}$, em 2001, (51,6 MPa). A razão dessa diferença pode ser explicada pelo fato de terem, esses autores, empregado áreas adesivas menores $\left(0,7 \mathrm{~mm}^{2}\right)$ em comparação com este e os demais trabalhos cujas áreas adesivas testadas eram de 0,95 a $1 \mathrm{~mm}^{2}$. 
Já nas superfícies que receberam as diferentes formulações de ácido bórico, geralmente observamos túbulos dentinários parcialmente obliterados evidenciando uma incompleta remoção da "smear layer" e a presença de "smear plugs" em algumas regiões.

Essa correlação entre capacidade desmineralizante e valor de resistência adesiva também foi encontrada em outros trabalhos WENDT,Jr; JEBELES; LEINFELDER ${ }^{120}$, STRICKAND et al. ${ }^{102,}$, DAVIS et al. ${ }^{27}$, AYAD; ROSENSTIEL; FARAG ${ }^{2}$ e BENDERLI; YUCEL ${ }^{9}$. Esses autores, apesar de apresentarem metodologias diferentes da utilizada neste trabalho, obtiveram maiores valores de resistência adesiva associados com a utilização de soluções ácidas com um maior poder de desmineralização e menores valores associados a outras soluções com menor poder de condicionamento.

Em contraposição, alguns autores não acreditam que exista uma correlação entre os valores de resistência adesiva e o padrão de condicionamento do substrato. GWINNETT $^{43}$, em 1994, acreditou que o grau de desmineralização da dentina não é um fator crítico em relação à resistência adesiva, principalmente quando é utilizada a técnica úmida. FINGER; INOUE; ASMUSSEN ${ }^{33}$, em 1994, salientaram a importância de uma eficaz infiltração da resina sobre a dentina desmineralizada, independentemente do grau de desmineralização da mesma. TEBECHRANI; MUENCH; JÚNIOR ${ }^{107}$, em 2000, observaram que não houve uma relação confiável entre padrão de condicionamento e valores de resistência adesiva e BLOMJOF et al. ${ }^{10}$, em 2001, observaram que, dependendo do sistema adesivo utilizado, o grau de desmineralização do substrato não interfere nos valores de resistência adesiva. 
Com relação aos grupos que sofreram condicionamento com as formulações de ácido bórico a 2\% (2,3,4 e 5), os grupos 2: solução de ácido bórico a 2\% por 30 segundos e 3: solução de ácido bórico a 2\% por 60 segundos e os grupos 4: gel de ácido bórico a 2\%, por 30 segundos e 5: gel de ácido bórico a 2\%, por 60 segundos, onde a única variável foi o fator tempo, não apresentaram diferenças estatísticas entre si. Geralmente, quando ácido fortes são aplicados sobre a dentina, um aumento no tempo de condicionamento não corresponde a um aumento nos valores de resistência $\operatorname{adesiva}^{51,75,84,107}$. Tempos excessivos de condicionamento dentinário, com esses tipos de ácidos, aumentam a profundidade de desmineralização que não é completamente impregnada pelo primer/adesivo ${ }^{75}$. Além disso, o aumento da trama exposta de colágeno pode provocar o seu colapso reduzindo a adesão. Adicionalmente, o excesso de condicionamento pode induzir a precipitação de cristais de fosfato de cálcio sobre a superfície e dificultar a penetração dos monômeros resinosos através da dentina desmineralizada ${ }^{84}$. BENDERLI; YUCEL ${ }^{9}$ acreditam que uma excessiva desmineralização dentinária, que se caracteriza pela remoção total da "smear layer" e de grande parte da dentina peritubular, acarretam abertura excessiva dos túbulos aumentando a umidade e o conteúdo protéico que podem afetar negativamente os valores de resistência adesiva.

Aparentemente, essas não são as situações que provocaram valores de resistência adesiva mais baixos quando da utilização das soluções de ácido bórico. Observa-se, na literatura, que um aumento no tempo de condicionamento com soluções ácidas consideradas fracas tende a produzir maior desmineralização dentináriaa,19,107 e a maiores valores de resistência adesiva ${ }^{9}$. Esta correlação é creditada à incapacidade desses ácidos fracos em remover a "smear layer" durante intervalos de tempos 
reduzidos. Entretanto, isso parece também não ter ocorrido com as formulações de ácido bórico, seja em forma líquida ou em forma de gel.

Face aos resultados obtidos com os grupos experimentais em que se emprega o sistema adesivo Single-bond, é lícito considerar que os baixos valores de adesão com o ácido bórico decorrem de seu baixo potencial desmineralizador e de um preparo inadequado do substrato dentinário para interagir com o sistema adesivo. Por se tratar de um agente condicionador experimental, sem praticamente qualquer informação adicional na literatura, há outras possibilidades a serem consideradas na relação causa/efeito do ácido bórico nos procedimentos adesivos. Pode-se mencionar, como exemplo de condição a ser estudada, o uso de concentrações mais altas para ajustá-lo a uma combinação de tempo de aplicação e efeito condicionador ideal.

Por outro lado, pôde-se ainda comparar que o sistema adesivo Single-Bond não apresenta ação coadjuvante importante sobre a resistência adesiva, do ponto de vista do efeito sobre o substrato dentinário, considerando-se seu $\mathrm{pH}$ relativamente alto e a julgar pelas imagens em MEV obtidas com esse material. As amostras tratadas somente com Single-Bond mostram um remanescente significativo da camada de agregados recobrindo a superfície dentinária e recobrindo os túbulos.

Quanto à apresentação do ácido (em forma líquida ou em gel), os grupos 2: (solução de ácido bórico a 2\% por 30 segundos) e 4: (gel de ácido bórico a 2\%, por 30 segundos) apresentaram diferenças estatísticas entre si. Já os grupos 3: (solução de ácido bórico a $2 \%$ por 60 segundos) e 5: (gel de ácido bórico a 2\%, por 60 segundos) não apresentaram diferenças estatisticamente significantes. Esses dados, como 
apresentados na tabela 1, mostram desempenho bastante semelhante entre as formulações de ácido bórico na forma líquida ou em gel, embora valores significantemente mais baixos de resistência adesiva tenham sido registrados com a formulação gel por 30 segundos. De fato, ao se analisarem as imagens de microscopia eletrônica (Figs. 19,20,21,22) pode-se observar que o padrão de remoção da "smear layer" é bastante similar entre as formulações, com efeito apenas ligeiramente mais efetivo para as soluções líquidas. Pelo que se vê na figura 22 (ácido bórico gel por 60 segundos), pode-se hipotetizar que os géis, por serem mais espessos, estabelecem menos contato, caracterizado como irregular em relação à superfície dentinária, reduzindo seu efeito a despeito do tempo de aplicação. A fig.22 mostra diferentes padrões de condicionamento no mesmo espécime, o que, certamente, influi na resistência adesiva.

A partir daí, justifica-se a pergunta sobre a razão de formulações apresentadas em gel. Na formulação original, como apresentada por FRANCISCHONE et al. ${ }^{34}$, em 1984, o ácido bórico a 2\% tem pH 5,1. Isso lhe dá características de antesséptico suave, de concentração isotônica, bastante conveniente do ponto de vista biológico. Ao se combinar a solução de ácido bórico a 2\% com o Carbopol, o gel formado passa a ter pH em torno de 2,9, o que em tese lhe daria maior potencial desmineralizador. Isso, entretanto, não ocorreu, como já discutido anteriormente, provavelmente devido à tensão superficial aumentada pelo gel relativamente à energia de superfície da dentina desgastada. Assim, o poder desmineralizador do gel permanece em torno dos mesmos $50-70 \%$ relatados por FRANCISCHONE et al. ${ }^{34}$ (1984). Por outro lado, os resultados do presente trabalho não repetiram os de PEREIRA ; CASTRO ${ }^{81}$ (1998). Esses autores registraram maior potencial desmineralizador das formulações em gel, quando comparados com as soluções líquidas, por igual tempo de condicionamento. Esses 
autores, entretanto, utilizaram a carboximetilcelulose como espessante a qual, embora mantendo o $\mathrm{pH}$ original da solução, permite melhor molhamento da superfície dentinária.

As primeiras soluções ácidas para o condicionamento dentário se apresentavam em forma de líquido. Porém, como existia um certo receio e um desconhecimento da interação das soluções ácidas com o complexo dentino pulpar, houve uma tendência em se substitiur as soluções líquidas pelas formulações em gel. Dessa forma, estas foram criadas para limitar a aplicação do ácido somente no esmalte, impedindo que o mesmo entrasse em contato com a dentina ${ }^{54,98}$. Alguns autores obtiveram valores adesivos superiores utilizando as formulações em gel comparado com as soluções líquidas ${ }^{98}$. Estes acreditam que os géis fornecem um substrato com melhores condições retentivas, provavelmente pela sua consistência viscosa, uma concentração uniforme da solução ácida e permanece por mais tempo sobre a superfície dentinária durante o tempo de aplicação ${ }^{98}$. Outra vantagem das formulações em gel seria a de evitar o evaporação do ácido ${ }^{54}$. Porém, outros autores acreditam que as soluções líquidas fornecem valores de resistência adesiva superiores comparados aos valores obtidos pelas formulações em gel, pois, principalmente os géis que utilizam espessantes à base de sílica e oxalato, deixam precipitados sobre a superfície impedindo uma boa adesão ${ }^{54}$. Outros trabalhos demonstram que, apesar destes precipitados realmente se mostrarem presentes, estes não influenciam nos valores de resistência adesiva ${ }^{77}$.

Quando se utilizou o sistema adesivo Prime \& Bond NT em associação com as diferentes soluções ácidas (grupo 7 a 11), os valores das médias de resistência adesivas 
dos diferentes grupos não apresentaram diferenças estatísticas significantes (32,74; 29,52; 29,28; 25,27; e 25,23 MPa respectivamente para cada grupo).

A literatura traz muitas informações sobre a resistência adesiva do Prime\&Bond NT em substratos dentinários condicionados com ácido fosfórico a 35\% 1,6,10,42, 66,67,76,92 . Os resultados do presente trabalho mostram que, em conformidade com o relatado na literatura $^{66,76}$, os valores de resistência adesiva são elevados quando se emprega o método tradicional de condicionamento, mas ainda inferiores àqueles obtidos por alguns outros autores ${ }^{67}$. Essas diferenças têm, possivelmente, relação com a variação das dimensões das áreas adesivas como, por exemplo, no trabalho de NUNES et al. ${ }^{67}$, que obtiveram resistência adesiva em torno de $48 \mathrm{MPa}$ para uma área de superfície de $0,7 \mathrm{~mm}^{2}$

Em um desses trabalhos citados acima, que estudam a interação dos sistemas adesivos da série Prime \& Bond com os substratos dentários, BARKMEIER; HAMMESFAHR; LATTA ${ }^{6}$, em 1999, utilizando o sistema adesivo Prime \& Bond 2.1 com e sem condicionamento ácido prévio, não observaram diferenças estatísticas significantes nas médias de resistência adesiva dos grupos. Os autores creditam essa equivalência de valores adesivos dos diferentes grupos a uma molécula presente na composição química da série Prime \& Bond de sistemas adesivos. Essa molécula (PENTA - dipentaerythritol penta-acrilato monofosfato), por possuir um baixo $\mathrm{pH}$, atua como um agente auto condicionamte quando em contato com a superfície da dentina. Assim, os autores acreditam que os sistemas adesivos da série Prime \& Bond possam ser usados na dentina sem a necessidade de um tratamento ácido prévio. Também, seguindo essa mesma linha de raciocínio, ROSA; PERDIGAO ${ }^{92}$, em 2000, obtiveram os 
mesmos resultados utilizando os sistemas Prime \& Bond NT e Prime \& Bond 2.1. Os autores acreditam que a molécula (PENTA - dipentaerythritol penta-acrilato monofosfato) presente na composição química de ambos os adesivos tem o poder de remover a "smear layer" e "smear plugs" dependendo da espessura da camada de agregados. Salientam, ainda, que essa molécula apenas modifica a "smear layer", não tendo a capacidade de desmineralizá- la. AGOSTINI et al. ${ }^{1}$, em 2001, após observarem os mesmos resultados dos trabalhos anteriores, constataram a capacidade desmineralizante do sistema adesivo Prime \& Bond NT. Com relação à composição do sistema adesivo, os autores relatam que a molécula PENTA possui grupos hidrofílicos e grupos hidrofóbicos, sendo que a porção hidrofílica da molécula é o grupo fosfórico. BLOMJOF et al. ${ }^{10}$, em 2001, também verificaram que o condicionamento com diferentes soluções ácidas não influenciou nos valores de resistência adesiva obtidos com o sistema adesivo Prime \& Bond NT. Salientam, ainda, que os primers que possuem nanopartículas em sua composição parecem ser menos sensíveis ao volume de fibras colágenas expostas pelo condicionamento ácido.

Porém, FERRARI et al. ${ }^{31}$, em 1999, contra-indicam o uso do sistema adesivo Prime \& Bond NT, tanto na dentina como no esmalte, sem um condicionamento ácido prévio, por acreditarem que o tratamento ácido é fundamental para a formação de uma camada híbrida uniforme, "tags" de resina e ramificações adesivas laterais. Assim, os autores acreditam que retenções micromecânicas não são criadas ao se utilizar o adesivo sem um condicionamento ácido prévio.

Assim, pode-se concluir que o potencial autocondicionante do sistema Prime\&Bond NT é certamente a causa dos valores relativamente elevados de resistência 
adesiva, quando empregado em associação com as formulações de ácido bórico, independente da forma de apresentação e do tempo de aplicação desses últimos, conforme exposto na tabela 2. Tal possibilidade é confirmada quando se comparam as superfícies condicionadas com ácido fosfórico a 35\% (Fig.18) e somente com Prime\&Bond NT (Fig.23). Assim se constata que o padrão de superfície condicionada em ambos os materiais é semelhante.

A rigor, os resultados nos levam a acreditar que as formulações de ácido bórico a $2 \%$, em solução e em forma de gel, aplicados pelos tempos de 30 e 60 segundos sobre a dentina, não fornecem substrato dentinário com características suficientes para que se obtenham resistências adesivas semelhantes às fornecidas pelo ácido fosfórico a 35\%. Baseando-se em alguns trabalhos da literatura, que preconizam valores adesivos mínimos necessários capazes de evitar infiltrações pela interface $e^{44,56,63,89}$ e suficientes para resistir às forças de contração dos materiais resinosos ${ }^{26}$, especula-se que as soluções experimentais com as características apresentadas no presente trabalho não devam ser utilizadas como opção para o condicionamento da dentina antes da aplicação dos sistemas adesivos.

Com relação ao sistema adesivo Prime \& Bond NT, maiores investigações sobre o processo interativo do mesmo com o substrato dentinário e com os materiais restauradores resinosos devem ser realizadas no futuro.

Em adição ao que se discutiu anteriormente, é importante completar que a despeito das variações de resultados de resistência adesiva, para ambos os sistemas utilizados, a observação das fractografias mostram concentração de fraturas adesivas 
dos corpos de prova. Em apenas alguns ensaios de tração foram observadas fraturas mistas e, em nenhum deles, fratura coesiva pura (Figs. 9,10,11). Isso leva a crer que, nas condições testadas neste trabalho, a qualidade de união com o substrato dentinário ainda é inferior à resistência dos próprios substratos. 


\section{2. B - Ensaios de resistência adesiva no esmalte.}

No esmalte, devido à prevalência de compostos inorgânicos em sua composição, o processo adesivo não é tão complexo como na dentina. Assim, é realizada a aplicação de uma solução ácida sobre a superfície do esmalte a qual desmineraliza seletivamente os prismas e cria irregularidades no substrato. Após a aplicação da solução ácida, monômeros resinosos são aplicados e estes se difundem pelas irregularidades criando uma forte retenção micromecânica entre o substrato e o material adesivo ${ }^{31,38,90}$. Esse fenômeno fornece altos valores adesivos dos materiais resinosos ao esmalte.

Quando se utilizou o sistema adesivo Single-Bond em associação com as diferentes soluções ácidas (Tabela 4), observa-se que os valores médios de resistência adesiva dos espécimes tratados com ácido fosfórico a 35\% (36,92 MPa) foram significantemente mais altos $(11,53 ; 11,22 ; 10,06$ e 13,11 MPa respectivamente). Os demais grupos não apresentaram diferenças estatisticamente significantes. A mesma tendência, com pequenas variações de significância, foi observada nos espécimes em que se empregou o Prime\&Bond NT. Também aqui, os resultados de resistência adesiva obtidos com ácido bórico, líquido ou em gel, por 30 segundos ou 1 minuto, foram significantemente inferiores àqueles obtidos com ácido fosfórico. A exceção constada refere-se ao grupo condicionado por ácido bórico gel, por 1 minuto, o qual registrou resistência adesiva estatisticamente significante quando comparado com o grupo em que se empregou a mesma formulação por 30 segundos (Tabela 5). Assim, a discussão que segue não fará distinção entre os dois sistemas adesivos empregados. 
O estudo do padrão de condicionamento ácido do esmalte revelou, como mostram as imagens em MEV (Figs.25 a 30), diferentes padrões de superfície. A superfície que recebeu o tratamento com ácido fosfórico a 35\%, por 30 segundos, apresentou uma completa remoção da "smear layer", evidenciando claramente os prismas de esmalte. Pode-se observar um padrão tipo 2 de condicionamento de acordo com SILVERSTONE et al. $^{99}$, em 1975, o qual se caracteriza por uma maior desmineralização da periferia dos prismas em relação à parte central dos mesmos (Fig. 26)

Esses dados encontram correspondência em observações constatadas em outros trabalhos $39,40,50,71,105,110,117$ os quais possibilitam altos valores de resistência adesiva do Single-Bond ao esmalte condicionado com ácido fosfórico a 37\% KANEMURA; SANO; TAGAMI ${ }^{55}$, em 1999, 29,3 MPa e SHIMADA; TAGAMI ${ }^{96}$, em 2003, 40,1 Mpa).

As demais soluções condicionadoras apresentaram padrões variados de remoção da "smear layer", todas bastante diferentes daquelas tratadas com o ácido fosfórico, exceto para o grupo do ácido bórico na forma líquida, por 1 minuto. Os espécimes desse grupo mostram um padrão de condicionamento, também do tipo 2 (Fig.28), porém menos agressivo que o conseguido com ácido fosfórico. Interessante notar que nos espécimes tratados com ácido bórico gel, por 1minuto (Fig. 30), percebe-se a tendência de apresentação de padrões de condicionamento diferentes na mesma superfície, como observado em dentina, sugerindo contato irregular do gel com o esmalte. Entretanto, a diferença no padrão de condicionamento não encontra correspondência nos valores de resistência adesiva entre os diferentes grupos testados. Essas observações indicam que, 
para o esmalte, é necessário mais que a simples exposição dos prismas de esmalte para alcançar efetiva retenção micromecânica mas, também, o completo desnudamento dos cristalitos e seus interespaços. Autores como BRESCHI et al. ${ }^{15}$, em 1999, FERRARI et al. $^{31}$, em 1999, AGOSTINI; KAADEN; POWERS ${ }^{1}$, em 2001 e ROSA; PERDIGÃO ${ }^{92}$, em 2000, acreditam que uma ineficaz desmineralização do esmalte não possibilita a formação de "tags" de resina na superfície do esmalte, resultando em baixos valores de resistência adesiva ${ }^{92}$.

Podemos observar nos trabalhos de TRIOLO JNIOR. et al. ${ }^{109}$, em 1993, SWIFT JUNIOR; CLOE ${ }^{105}$, em 1993, HOLTAN et al. ${ }^{47}$, em 1995, ORTEGA; SILVA e SOUZA Jr.; FRANCO ${ }^{71}$, em 1997 e GARDNER; HOBSON ${ }^{39}$, em 2001, os mesmos resultados obtidos em nosso trabalho, que se caracterizou por apresentar maiores valores de resistência adesiva ao esmalte relacionado com soluções ácidas com maior poder desmineralizante e menores valores associados a soluções ácidas com menor poder desmineralizante.

Há, contudo, controvérsia quanto à relação do poder desmineralizador dos ácidos e da resistência adesiva. Autores como TRIOLO JUNIOR et al. ${ }^{109}$, em 1993, SWIFT Jr.; CLOE ${ }^{105}$, em 1993, HOLTAN et al. ${ }^{47}$, em 1995, ORTEGA; SILVA e SOUZA Jr.; FRANCO ${ }^{71}$, em 1997, e GARDNER; HOBSON ${ }^{39}$, em 2001, de fato observaram maiores valores de resistência adesiva ao esmalte condicionado com ácido de maior poder desmineralizador (ácido fosfórico a 10, 35 e 37\%) em comparação com os mais fracos (ácido nítrico a 2,5\%,ácido maleico a 10\%, ácido oxálico/nitrato de alumínio e ácido oxálico 1,6\%) e associaram os baixos valores de resistência adesiva dos ácidos mais fracos com padrões de condicionamento caracterizados por uma 
ineficaz desmineralização do esmalte. Outros autores ${ }^{29,87,111}$, entretanto, consideram que o padrão de condicionamento do esmalte é apenas um dos aspectos a serem considerados. A associação de fatores como a qualidade do esmalte, o padrão de remoção de cálcio e a eliminação de precipitados decorrentes do condicionamento parece ter mais importância que o potencial desmineralizador isoladamente ${ }^{46,58,111}$.

O mesmo raciocínio pode ser explicado com relação ao tempo de condicionamento. Tempos prolongados de ação do ácido fosfórico, dentro de uma certa extensão, não melhoram significantemente a resistência adesiva embora exerçam, progressivamente, efeito negativo correspondente na qualidade da resistência adesiva. Sabe-se que tempos excessivos de condicionamento provocam desmineralização pouco uniforme, enfraquecimento estrutural do esmalte e remoção de cálcio numa extensão que pode não ser compensada pela impregnação dos sistemas adesivos $4,5,8,44,109,110,117$. Todavia, para as demais formulações empregadas no presente estudo, os tempos de 30 segundos e 1 minuto não foram suficientes para garantir valores de resistência adesiva satisfatórios. Aqui, fica evidente a necessidade do ajuste da combinação concentração/tempo de condicionamento para as formulações de ácido bórico.

O emprego de soluções ácidas fracas não foi tão investigado no esmalte como o foi sobre a dentina. Apesar de alguns trabalhos demonstrarem que com o aumento do tempo de condicionamento ácido, com estas soluções descritas acima, ocorre um aumento nos valores de resistência adesiva $a^{47,109}$ e um melhor padrão de condicionamento do esmalte ${ }^{39}$, observamos em nosso trabalho, corroborando os achados de HALLET; GARCIA-GODOY; TROTTER ${ }^{46}$, em 1994, e HOLTAN et al. ${ }^{47}$, em 1995, que utilizaram os ácidos maleico a $10 \%$ e oxálico a 1,6\%, valores adesivos 
similares após a utilização de diferentes tempos de condicionamento (grupos 2: 11,53; 3: 11,22; 4: 10,06 e 5: 13,11 Mpa) . Com relação ao padrão de condicionamento das diferentes formulações de ácido bórico a 2\%, apenas a solução de ácido bórico a 2\%, por 60 segundos, apresentou uma maior capacidade desmineralizante, característica esta que não se relacionou com um aumento nos valores de resistência adesiva. Essa falta de correlação entre o padrão de condicionamento do substrato e os valores de resistência adesiva também foi encontrada nos trabalhos de BEECH; JALALY ${ }^{8}$, em 1980, WANG; LU ${ }^{117}$, em 1991, GWINNETT; GARCIA-GODOY ${ }^{44}$, em 1992, BARKMEIER; GWINNETT; SHAFFER ${ }^{4}$, em 1985, BARKMEIER; GWINNETT; SHAFFER ${ }^{5}$, em 1987, UNO; FINGER ${ }^{110}$, em 1995 e TRIOLO JUNIOR et al. ${ }^{109}$, em 1993.

O estudo sobre a forma de apresentação das soluções ácidas e suas respectivas interações com o esmalte sempre despertou interesse, principalmente devido ao receio dos possíveis malefícios que essas soluções poderiam causar sobre a dentina. Inúmeros trabalhos foram realizados com o intuito de se compararem as formulações ácidas, líquidas e em forma de gel, com relação ao padrão de condicionamento e aos valores de resistência adesiva ${ }^{3,13,14,16,38,40,58,70,102,111,116}$.

Apesar de alguns trabalhos encontrarem diferenças entre o padrão de condicionamento das formulações ácidas em suas diferentes formas de apresentação 3,101, a grande maioria dos autores não observou diferenças tanto no padrão de condicionamento quanto nos valores de resistência adesiva após a utilização das formulações ácidas líquidas e em forma de gel ${ }^{13,14,16,38,58,70,111,116}$. 
Os resultados do presente trabalho coincidem com os de WALKER; VANN ${ }^{116}$, em 1984; MAC COLL et al. ${ }^{58}$, em 1998 e O’ BRIEN et al. ${ }^{70}$, em 1987, os quais não observaram diferenças nos valores de resistência adesiva após a utilização das formulações ácidas líquidas e em de gel. Assim, é preconizado o uso dos géis pois estes apresentam algumas vantagens como melhor controle durante a aplicação da solução ácida, evitando o contato com dentes vizinhos com o tecido gengival e tecido dentinário; facilidade de se condicionarem as superfícies linguais e dentes parcialmente irrompidos $14,16,40,58$.

O poder auto condicionante do sistema adesivo Prime \& Bond NT, observado na dentina, não foi observado no esmalte. O estudo do padrão de condicionamento em microscopia eletrônica demonstrou a ineficiência do sistema adesivo, descrito acima, em desmineralizar o esmalte. Na superfície de esmalte onde foi aplicado o sistema adesivo Prime \& Bond NT, de acordo com as indicações do fabricante, pôde-se observar uma área quase que totalmente coberta por uma camada de substância amorfa, não sendo possível a visualização dos prismas de esmalte. Nota-se a presença da "smear layer" recobrindo a superfície e obliterando-a quase que totalmente (Fig. 31). Estes achados estão de acordo com os trabalhos de BRESCHI et al. ${ }^{15}$, em 1999, FERRARI et al. ${ }^{31}$, em 1999, AGOSTINI; KAADEN; POWERS ${ }^{1}$, em 2001 e ROSA; PERDIGÃO ${ }^{90}$, em 2000. Esses autores acreditam que, apesar da presença da molécula PENTA na composição do sistema adesivo, esta é imcapaz de desmineralizar o esmalte; assim, "tags" de resina não são formados na superfície do esmalte ${ }^{31}$ resultando em baixos valores de resistência adesiva ${ }^{90}$. Porém, RABELLO et al. ${ }^{85}$, em 2002, não encontraram diferenças estatísticas significantes nos valores de resistência adesiva entre grupos com 
e sem condicionamento ácido prévio à aplicação do sistema adesivo Prime \& Bond NT no esmalte.

Apesar dos baixos valores adesivos obtidos com as soluções de ácido bórico a $2 \%$, tanto na dentina como no esmalte, acreditamos que maiores investigações possam ser realizadas com esta mesma solução ácida em concentrações ou tempos diferentes do utilizado em nosso trabalho. 


\section{7 - CONCLUSÃO}

Com base nos resultados obtidos, podemos concluir que:

o tratamento superficial da dentina e do esmalte com as soluções de ácido bórico a $2 \%$, em forma líquida e em forma de gel, não fornece substratos com características suficientes para proporcionar resistência adesiva semelhante à fornecida pelo ácido fosfórico a 35\%;

- $\quad$ em dentina, o sistema adesivo Prime\&Bond NT atua como verdadeiro autocondicionante, apresentando um padrão de superfície dentinário semelhante ao do ácido fosfórico;

- $\quad$ os elevados valores de resistência adesiva obtidos em dentina nos grupos em que foram utilizadas as diferentes apresentações e tempos de condicionamento, com ácido bórico, são resultantes da ação conjunta do ácido bórico e do sistema adesivo Prime\&Bond NT;

- a adesão nos espécimes tratados com a combinação das respectivas condições do ácido bórico e sistema adesivo Prime\&Bond NT, em dentina não se repetem em esmalte;

- $\quad$ em razão das conclusões obtidas, podemos sugerir que estudos futuros, com ácido bórico como agente condicionador, dos substratos dentários devem levar em conta variações na concentração e no tipo de espessante empregado. 


\section{REFERÊNCIAS BIBLIOGRÁFICAS*.}

1. AGOSTINI, F.G.; KAADEN, C.; POWERS, J.M. Bond strength of self-etching primers to enamel and dentin of primary teeth. Pediat. Dent., v.23, n.6, p.481-6, Nov./Dec. 2001.

2. AYAD, M.F.; ROSENSTIEL, S.F.; FARAG, A. M. A pilot study of lactic acid as an enamel and dentin conditioner for dentin-bonding agent development. J. prosth. Dent., v.76, n.3, p.254-9, Sept. 1996.

3. BAHARAV, H. et al. The efficacy of liquid and gel acid etchants. J. prosth. Dent., v.60, n. 5, p.545-7, Nov. 1998.

4. BARKMEIER, W.W; GWINNETT, A.J.; SHAFFER, S.E. Effects of enamel etching time on bond strength and morphology. J. Clin. Orthod., v.19, n.1, p.36-8, Jan. 1985.

5. BARKMEIER, W.W; GWINNETT, A.J.; SHAFFER, S.E. Effects of reduced acid concentration and etching time on bond strength and enamel morphology. J. Clin. Orthod., v.21, n.6, p.395-8, June. 1987.

6. BARKMEIER, W.W.; HAMMESFAHR,P.D.; LATTA, M.A. Bond strength of composite to enamel and dentin using Prime \& Bond 2.1. Oper. Dent., v.24, n.1, p.51-6, 1999 .

7. BARKMEIER, W.W; SHAFFER, S.E; GWINNETT, A.J. Effects of 15 vs 60 second enamel acid cond itioning on adhesion and morphology. Oper. Dent., v.11, p.111-6, 1986.

8. BEECH, D.R.; JALALY, T. Bonding of polymers to enamel: influence of deposits formed during etching, etching time and period of water immersion.

J. dent. Res., v.59, n.7, p.1156-62, July 1980.

* Normas recomendadas para uso no âmbito da Universidade de São Paulo, com base no documento "Referências Bibliográficas: exemplos", emanado do Conselho Supervisor do Sistema Integrado de Bibliotecas da USP, em reunião de 20 de setembro de 1990. 
9. BENDERLI, Y; YUCEL, T. The effect of surface treatment on the bond strength of resin composite to dentin. Oper. Dent., v.24, n.2, p.96-102, Mar/Apr. 1999.

10. BLOMLOF, J. et al. Acid conditioning combined with single-component and two-component dentin bonding agents. Quint. Int., v. 32, n.9, p.711-5, Oct. 2001.

11. BOWEN, R.L. Properties of a silica: reinforced polimer for dental restorations.

J. Amer. dent. Ass., v. 66, p. 58-64, 1963.

12. BRANNSTROM, M.; JOHNSON, G.: Effects of various conditioners and cleaning agents on prepared dentin surfaces: a scanning electron microscopic investigation. J. prosth. Dent., v.31, p.422-30, Apr. 1974.

13. BRANNSTROM, M.; MALMGREN, O.; NORDENVALL,K.J. Etching of young permanent teeth with an acid gel. Amer. J. Orthod., v.82, n.5, p.37983, Nov. 1982.

14. BRANNSTROM, M.; NORDENVALL, K.J.; MALMGREN, O. The effect of various pretreatment methods of the enamel in bonding procedures. Amer. J. Orthod., v.74, n.5, p.522-30, Nov. 1978.

15. BRESCHI, L. et al. Ultramorphology and shear bond strengths of self-etching adhesives on enamel. J. dent. Res., v.78, p.475, 1999. Abstract.

16. BROWN, M.R. Penetration of gel and solution etchants in occlusal fissures. ASDC J. Dent. Child., V.55,n.4, p. 265-8, July/Aug. 1988.

17. BUONOCORE, M.G. A simple me thod of increasing the adhesion of acrilyc filling materias to enamel surfaces. J. dent. Res., v.34, p. 849-53, 1955. 
18. BUONOCORE, M.; WILEMAN, W.; BRUDEVOLD,F. A report on a resin composition capable of bonding to human dentin surfaces. J. dent. Res., v.35, n.6, p.846-51, Dec. 1956.

19. CAMPS, J. et al. Influence of concentration and application time of maleic acid on dentin permeability. Dent. Mat., v.11, n.3, p.177-81, May 1995.

20. CÂNDIDO, M.S.M. Efeito de alguns agentes de limpeza sobre a dentina observado através de microscópio eletrônico de varredura. Bauru, 1990, Dissertação (Mestrado) - Faculdade de Odontologia de Bauru, Universidade de São Paulo.

21. CARDOSO, P.E.C.; BRAGA, R.R.; CARRILHO, M.R.O. Evaluation of microtensile, shear and tensile tests determining the bond strength of three adhesive systems. Dent. Mat., v.14, n.6, p.394 - 8, Nov. 1998.

22. CARVALHO, R.M. et al. Determinação da resistência adesiva à dentina através de um dispositivo de microtração. Rev. Fac. Odont. Bauru, v.2, n.3, p.7782, jul./set. 1994.

23. CASTRO, M.V. F. Avaliação microscópica do condicionamento da dentina com ácidos fosfórico e bórico. Bauru, 2000 79p. Dissertação (Mestrado) Faculdade de Odontologia de Bauru, Universidade de São Paulo.

24. CHAPPELL, R. P. et al. Dentinal tubule anastomosis: a potencial factor in adhesive bonding? J. prosth. Dent., v.72, n.2, p.183-8, Aug. 1994.

25. CORDEIRO, H. J. D.; VILELLA, L. C.; NETTO, C.A. Estudo comparativo da resistência à tração de adesivos dentinários com tratamento e com remoção total da "smear layer" - estudo in vitro. RPG Rev. Pós Grad. v. 6, n. 3, p. 199-206, July/Dec. 1999. 
26. DAVIDSON, C.L.; GEE, A.J.; FEILZER, A. The competition between the composite-dentin bond strength and the polymerization contraction stress. $\mathbf{J}$. dent. Res., v.63, n.12, p.1396-9, Dec. 1984.

27. DAVIS, E. L. et al. Adhesion of dentin bonding agents after smear layer treatments. Amer. J. Dent., v. 5, n.1, p. 29-32, Feb. 1992.

28. DELLA BONA, A.; VAN NOORT, R. Shear vs. Tensile bond strength of resin composite bonding to ceramic. J. dent. Res., v.74, n.9, p.1591-6, Sept.1995

29. FARQUHAR, R. B. Direct bonding comparing a polyacrylic acid and a phosphoric acid technique. Amer. J. Orthod. Dentofacial Orthop., v.90, n.3, p.187-94, Sept. 1986.

30. FAVA, M. et al. Observations on etched enamel in non-erupted deciduous molars: a scanning electron microscopic study. Rev. Odont. Univ. São Paulo. v.11, n.3, p.157-60, jul/set. 1997.

31. FERRARI, M. et al. Standardized microscopic evaluation of the bonding mechanism of NRC/Prime\&Bond NT. Amer. J. Dent., v.12, n.2, p.77-83, Apr. 1999.

32. FORTES, C. M.; STEAGALL, L. Efeito de concentrações do ácido fosfórico no esmalte. Rev. gaúcha Odont., v.36, n.2, p.154-8, mar/abr. 1988.

33. FINGER, M.J.; INOUE, M; ASMUSSEN, E. Effect of wettability of adhesive resins on bonding to dentin. Amer. J. Dent., v.7, n.1, p.35-8, Feb. 1994.

34. FRANCISCHONE, C .E. et al. Efeito de alguns agentes de limpeza sobre a dentina, observado através de microscopia eletrônica de varredura. Estomat. Cult., v.14, n.1/2, p- 48-56, jan/ jun. 1984.

35. FUSAYAMA, T. et al. Non-pressure adhesion of a new adhesive restorative resin. J. dent. Res., v.58, n.4, p.1364-70, Apr.1979. 
36. GARCIA, F. C. P. et al. Testes mecânicos para a avaliação laboratorial da união resina/dentina. Rev. Fac. Odont. Bauru, v.10, n. 3, p.-63-7, 2002.

37. GARCIA-GODOY, F.; MALONE, W.F.P. Penetration of acid gel etchants into cavity walls: an SEM evaluation. Quint. Int., v.18, n.7, p.481-5, July 1987.

38. GARCIA-GODOY, F; GWINNETT, A.J. Penetration of acid solution and gel in occlusal fissures. J. Amer. Dent. Ass. v. 114, n.6, p. 809-10, June1987.

39. GARDNER, A.; HOBSON, R. Variations in acid-etch patterns with different acids and etch times. Amer. J. Orthod. Dentofacial, v.120, n. 1, p.64-7, July 2001.

40. GILPATRICK, R. O.; ROSS, J. A.; SIMONSEN, R. J. Resin-to-enamel bond strengths with various etching times. Quint. Int., v.22, n.1, p.47-9, Jan. 1991.

41. GOTTLIEB, E.W. et al. An optimal concentration of phosphoric acid as an etching agent. Part I: tensile bond strength studies. J. prosth. Dent., v.48, n.1, p.48-51, July 1980.

42. GREGOIRE, G.L.; AKON, B.A.; MILLAS, A. Interfacial micromorphological differences in hybrid layer formation between water-and solvent-based dentin bonding systems. J. prosth. Dent., v.67, n. 6, p.633-41, June 2002.

43. GWINNETT, A. J. Altered tissue contribution to interfacial bond strength with acid conditioned dentin. Amer. J. Dent., v.7, n.5, p.243-6, Oct. 1994.

44. GWINNETT, A. J.; GARCIA-GODOY, F. Effect of etching time and acid concentration on resin shear bond strength to primary tooth enamel. Amer. J. Dent., v. 5, n. 5, p. 237-9, Oct. 1992. 
45. GWINNETT, A. J; KANCA, J.A. Micromorphology of the bonded dentin interface and its relationship to bond strength. Amer. J. Dent., v.5, n.2, p.73-7, 1992.

46. HALLETT, K.B.; GARCIA-GODOY, F.; TROTTER, A.R. Shear bond strength of a resin composite to enamel etched with maleic or phosphoric acid. Aust. Dent. J. v.39, n.5, p.292-7, Oct. 1994.

47. HOLTAN, J.R. et al. Influence of different etchantsand etching times on shear bond strength. Oper. Dent., v.20, n.3, p.94-9, May/June 1995

48. HOSOYA, Y. Resin adhesion to the ground young permanent enamel: influence of etching times and thermal cycling test. J. Clin. Pediat. Dent., v.18, n.2, p.115-22, 1994.

49. JOVANOVIC, R.; CONGEMA, E.; NGUYEN, H.T. Antifungal agents vs. boric acid for treating chronic mycotic vulvovaginitis. J. Reprod. Med. v.36, p.593-7,1977.

50. JOHNSTON, C.D. et al. Bonding to molars - the effect of etch time (an in vitro study). Eur. J. Orthod., v.20, n.2, p.195-9, Apr. 1998.

51. JACOBSEN, T. et al. Calcium leaching from dentin and shear bond strength after etching with phosphoric acid of different concentrations. Eur. J. oral Sc., v.108, n. 3, p.247-54, June 2000.

52. KANCA, J. A method for bonding to tooth structure using phosphoric acid as a dentin-enamel conditioner. Quint. Int., v.22, n. 4, p.285-90, Apr. 1991.

53. KANCA, J. Improving bond strength through acid etching of dentin and bonding to wet dentin surfaces. J. Amer. dent. Ass., v.123, n.9, p.35-43, Sept. 1992.

54. KANCA, J. Etchant composition and bond strength to dentin. Amer. J. Dent., v.6, n.6, p.287-90, Dec. 1993. 
55. KANEMURA, N.; SANO, H; TAGAMI, J. Tensile bond strength to and SEM evaluation of ground and intact enamel surfaces. J. Dent., v.27, n.7, p.52330, Sept. 1999.

56. KOMATSU, M.; FINGER, W. Dentin bonding agents: correlation of early bond strength with marginal gaps. Dent. Mat., v.2, p.257-62, 1986.

57. LEE JUNIOR, H. L. et al. Effects of acid etchants on dentin. J. dent. Res., v.52, n.6, p.1228-33, Nov./ Dec. 1973.

58. MACCOLL, G.A. et al. The relationship between bond strength and orthodontic bracket base surface area with conventional and microetched foil-mesh bases. Amer. J. Orthod. Dentofacial Orthop., v.113, n.3, p.276-81, Mar. 1998.

59. MATOS, A.B. et al. Estudo "in vitro" de diversos agentes utilizados para limpeza de superficie dentinária. Rev. Pós-Grad. Fac. Odont., v.2, n.2, p. 37-44, abr/jun. 1995.

60. MERCH \& Co., Inc. The Merch Index. Ed. Centennial 1989.

61. MONDELLI, J. Proteção do complexo dentino-pulpar. São Paulo, Artes Médicas: EAP-APCD,1998.

62. MUENCH, A. Retenção de resina composta em função do método de aplicação da solução ácida, da orientação dos esforços e da refixação. Rev. Ass. paul. cirurg. dent.. v.30, n.6, p.299-302, set/out. 1976.

63. MUNKSGAARD, E.C.; IRIE, M.; ASMUSSEN, E. Dentin-polymer bond promoted by gluma and various resins. J. dent. Res. v.64, n.12, p.1409-11, Dec. 1985. 
64. NAKABAYASHI, N.; KOJIMA, K.; ; MASUHARA, E.: The promotion of adhesion by the infiltration of monomers into tooth substrates. J. Biomed. Mat. Res., v. 16, n.3, p.265-273, May 1982.

65. NAKAJIMA, M. et al. Comparative microtensile bond strength and SEM analysis of bonding to wet and dry dentin. Amer. J. Dent., v.13, n.6, p.324$8,2000$.

66. NAKAJIMA, M. et al. Dimensional changes and ultimate tensile strengths of wet decalcified dentin applied with one-bottle adhesives. Dent. Mat., v.18, p.603-8, 2002.

67. NUNES, M.F.; SWIFT,Jr.; E.J.; PERDIGÃO, J. Effects of adhesive composition on microtensile bond strength to human dentin. Amer. J. Dent., v.14, n.6, p.340-3, Dec. 2001.

68. OGATA, M. et al. Influence of the direction of tubules on bond strength to dentin. Oper. Dent., v.26, n.1, p.27-35, Jan/Feb. 2001.

69. OILO, G. Bond strength testing - what does it mean? Int. dent. J., v.43, n.5, p.492-8, Oct. 1993.

70. O' BRIEN III, J.A. et al. Effects of saliva contamination and phosphoric acid composition on bond strength. Dent. Mat., v.3, n.6, p.296-302, Dec.1987.

71. ORTEGA, R.C.S.; SILVA E SOUZA JUNIOR, M.H.; FRANCO, E.B. Influência de diferentes condicionadores ácidos na resistência adesiva de uma resina composta ao esmalte. Rev. bras. Odont., v. 54, n.5, p.268-72, set/out. 1997.

72. PASHLEY, D.H.; TAO, L. Shear bond strengths to dentin: effects of surface treatments, depth and position. Dent. Mat., v.4, n.6, p.371-8, Dec. 1988. 
73. PASHLEY, D.H. et al. Adhesion test of dentin bonding agents: a review. Dent. Mat., v.11, n.2, p.117-25, Mar. 1995.

74. PASHLEY, D.H et al. The microtensile bond test: a review. J. Adhes. Dent. v.1, n.4, p.299-309, 1999.

75. PAUL, S.J. et al. Nanoleakage at the dentin adhesive interface vs ìtensile bond strength. Oper.Dent., v.24, n.3, p.181-8, May/June 1999.

76. PERDIGÃO, J.; FRANKENBERGER, R. Effect of solvent and rewetting time on dentin adhesion. Quint. Int., v. 32, n.5, 2001.

77. PERDIGÃO, J.; DENEHY, G.E.; SWIFT, E.J. Adhesion of a totaletch phosphate ester bonding agent. Amer. J. Dent., v.7, p.149-52, 1994.

78. PERDIGÃO, J. et al. Field emission SEM comparison of four postfixation driving tecniques for human dentin, J. Biomed. Mat. Res., v. 29, p. 1111$20,1995$.

79. PERDIGÃO, J. et al. Effect of conditioner and restorative resin on enamel bond strengths. Amer. J. Dent., v. 13, n.2, p.88-92, Apr. 2000.

80. PERDIGÃO, J. et al. Effect of calcium removal on dentin bond strengths. Quint. Int., v.32, n.2, p.142-6, Feb. 2001.

81. PEREIRA, J.C.; CASTRO, M.V.F. Boric acid as an alternative for dentin etching -an electron microscopic study. Conference on Critical Review of Restorative Quandries,v.12, p.221-23. Oct.1998.

82. PEREIRA, J.C.; SEGALA A. D.; COSTA, C.A.S.: Human pulpal response to direct pulp capping with an adhesive system. Amer. J. Dent.,v.13, n.3, p.139-147, June 2000 
83. PEREIRA, J.C.; SEGALA, A. D.; COSTA, C.A.S.: Microscopic study of human pulps capped with a two-step smear layer removing system. J. dent. Res., v.79, p.202, 2000.

84. PIOCH, T. et al. Influence of different etching times on hybrid layer formation and tensile bond strength. Amer. J. Dent., v.11, n.5, p.202-6, Oct. 1998.

85. RABELLO, T. B. et al. Avaliação da resistência de união ao cisalhamento de diferentes técnicas adesivas em esmalte. Rev. bras. Odont., v. 59, n. 1, p. 22 - 4. jan/fev. 2002.

86. REIFEIS, P.E.; COCHRAN, M. A.; MOORE, B.K. An in vitro shear bond strength study of enamel/dentin bonding systems on enamel. Oper. Dent., v.20, n.5, p.174-9, Sept/Oct.1995.

87. RETIEF, D. H. A comparative study of three etching solutions. J. oral Rehabil., v. 1, n.4, p.381-390, Oct. 1974.

88. RETIEF, D.H. Standardizing laboratory adhesion tests. Amer. J. Dent., v.4, n.5, p.231-6, Oct.1991.

89. RETIEF, D.H.; MANDRAS, R. S.; RUSSELL, C.M. Shear bond strength required to prevent microleakage at the dentin/restoration interface. Amer. J. Dent., v.7, n.1, p.43-6, Feb.1994.

90. RETIEF, D.H. et al. Pyruvic acid as an etching agent in clinical dentistry. J. Biomed Mat. Res., v. 19, p.335-48,1985.

91. RETIEF, D.H et al. A laboratory evaluation of three etching solutions. Dent. Mat., v.2, n.5, p.202-6, 1986.

92. ROSA, B.T.; PERDIGÃO, J. Bond strengths of nonrinsing adhesives. Quint. Int., v.31, n.5, p.353-8, May 2000. 
93. SANO, H. et al. Relationship between surface area for adhesion and tensile bond strength - Evaluation of a micro-tensile bond test. Dent. Mat., v.10, n.4, p.236-40, July 1994.

94. SANO, H. et al. Tensile Properties of mineralized and demineralized human and bovine dentin. J. dent. Res., v.13, n.6, p.1205-11, Jun. 1994.

95. SCHREINER, R. F. et al. Microtensile testing of dentin adhesives. Dent. Mater., v.14, n. 3, p.194-201, June 1998.

96. SHIMADA, Y.; TAGAMI, J. Effects of regional enamel and prism orientation on resin bonding. Oper. Dent., v. 28, n.1, p.20-7, Jan./Fev. 2003.

97. SHONO, Y. et al. Effects of surface area on resin-enamel tensile bond strength. Dent. Mat., v.13, n. 5, p. 290-6, Sept. 1997.

98. SILVA E SOUZA, M.H. Efeito de alguns tratamentos de superfície em dentina na resistência adesiva de uma resina composta. Bol. Inf. GBPD, v.9, n.1-2, p.36-7, 1986.

99. SILVERSTONE, L.M. et al. Variation in the pattern of acid etching of human dental enamel examined by scanning electron microscopy. Caries Res., v.9, n.5, p.373-87, 1975.

100. SKINNER, G.R.B. et al. Possible treatment for cold sores. B.M.J. v.2, p.704,1979.

101. SOUZA, L.C.; UTRILLA, L.B.; GABRIELLI, F. Morfologia das projeções dos diferentes tipos de resinas aplicadas no esmalte atacado por ácido gel e solução. Rev. Odont. UNESP, v.17, n.1, p.19-26, 1988

102. STRICKLAND, S.S. et al. Gluma shear bond strength to enamel and dentin treated with pyruvic acid and glycine. Amer. J. Dent., v.5, n.2, p.97-102, Apr. 1992. 
103. SUDSANGIAM, S.; VAN NOORT, R. Do dentin bond strength tests serve a useful purpose? J. Adhes. Dent., v.1, n1, p.57-67, 1999.

104. SWIFT JUNIOR, E.J.; DENEHY, G.E.; BECK, M.D. Use of phosphoric acid etchants with Scotchbond Multi-Purpose. Amer. J. Dent., v.6, n.2, p.88-90, Apr. 1993.

105. SWIFT JUNIOR, E.J.; CLOE, B.C. Shear bond strengths of new enamel etchants. Amer. J. Dent., v.6, n.3, p.162-4 ,June. 1993.

106. TATE, W.H.; YOU, C.; POWERS, J.M. Bond strength of compomers to dentin using acidic primers. Amer. J. Dent., v.12, n.5, p.235-42, Oct. 1999.

107. TEBECHRANI, C.; MUENCH, A.; JÚNIOR, W. G. M. Estudo in vitro da influência do condicionamento ácido e da superfície, em dentina de dentes decíduos, na resistência de união de resina composta e na micromorfologia dessa dentina condicionada. Rev. Pós-Grad. USP, v.7, n.2, p.114-9, abr/jun. 2000.

108. TERADA, R.S.S. Mapeamento da variação regional da resistência adesiva em superfícies planas de dentina. Bauru, 2001, Tese (Doutorado) 177 p. Faculdade de Odontologia de Bauru., Universidade de São Paulo.

109. TRIOLO JUNIOR., P. T. et al. Effects of etching time on enamel bond strengths. Amer. J. Dent., v.6, n.6, p.302-4, Dec.1993.

110. UNO, S.; FINGER, W.J. Effect of acid etchant composition and etch duration on enamel loss and resin composite bonding. Amer. J. Dent., v.8, n.4, p.165-9, Aug.1995.

111. VAN DER VYEER, P. J.; DE WET, F.A.; JANSEN VAN RENSBURG, J.M. Bonding of composite resin using different enamel etchants. J. dent. Ass. S. Afr., v.52, n.3, p.169-72, Mar. 1997. 
112. VAN NOORT, R. et al. A critique of bond strength measurements. J.Dent., v.17, n.2, p.61-7, Apr. 1989.

113. VAN NOORT, R. Clinical relevance of laboratory studies on dental materials: strength determination - a personal view. J. Dent., v.22, p.4-8, 1994. Suppl.1.

114. VAN SLIKE, R.H.; MICHEL, V.P.; REIN, M.F. Treatment of vulvovaginal candidiasis with boric acid powder. Amer. J. Obstet. Gynecol. v.141,p.145,1981

115. VERSLUIS, A.; TANTBIROJN, D.; DOUGLAS, W. H. Why do shear bond tests pull out dentin? J. dent. Res., v.76, n.6, p.1298-307, June1997.

116. WALKER, M.L.; VANN JUNIOR., W.F. In vitro comparison of primary incisor enamel surfaces etched with an acid solution or acid gel. Ped. Dent., v.6, n.4, p.209-13, Dec. 1984.

117. WANG, W.N.; LU, T.C. Bond strength with various etching times on young permanent teeth. Amer. J. Orthod. Dentofacial Orthop., v.100, n.1, p.72-9, July. 1991.

118. WANG, W.N. et al. Effect of $\mathrm{H}_{3} \mathrm{PO}_{4}$ concentration on bond strength. Angle Orthod., v. 64, n.5, p.377-82, 1994.

119. WASUNDHARA, A. B.; HAZAREY, P. V. Scanning electron microscopic study and shear bond strength measurement with $5 \%$ and $37 \%$ phosphoric acid. Amer. J. Orthod. Dentofacial Orthop., v.108, n.4, p.410-4, Oct. 1995.

120. WENDT JUNIOR, S.L.; JEBELES, C.A.; LEINFELDER, K.F. The effect of two smear layer cleansers on shear bond strength to dentin. Dent. Mat., v.6, n.1, p.1-4, Jan. 1990. 


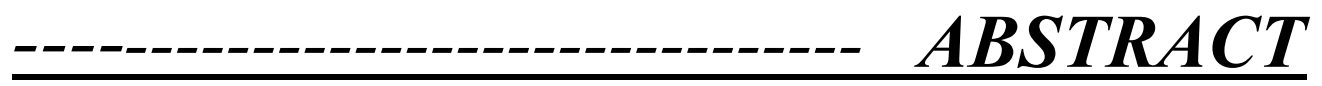




\begin{abstract}
The aim of this laboratory work was to evaluate the bond strength and etching pattern of dentin and enamel conditioned by $2 \%$ boric acid. In this study, human third molars etched with $35 \%$ phosphoric acid and different solutions of $2 \%$ boric acid were utilized. For the etching pattern determination discs of dentin and square enamel specimens were conditioned (35\% phosphoric acid and $2 \%$ boric acid solutions) and prepared for scanning electron microscopic observations. For dentin and enamel bond strengths evaluation the microtensile test was used. Phosphoric acid (35\%) and boric acid $(2 \%)$ were utilized in combination with two adhesive systems (Single-Bond and Prime \& Bond NT) and two different composite resins (Z-250 and TPH). After bonding procedures, the teeth were sectioned and the obtained specimens submitted for microtensile tests. The results were analyzed by ANOVA followed Tukey's analysis at a significance level of $5 \%(p<0,05)$. The $35 \%$ phosphoric acid solution presented higher demineralization power when compared to $2 \%$ boric acid solutions either in dentin or enamel. Regarding to the bond strength in dentin, when $35 \%$ phosphoric acid solution was used in combination with Single-Bond adhesive system and Z 250 composite resin the values were significantly higher when compared to other acid solutions. Therefore, whem the Prime \& Bond NT adhesive system and TPH composite resin were utilized, no statisticaly different values were demonstrated for bond strenght among different acid solutions. In enamel, different acid solutions were also combined with Single-Bond and Prime \& Bond adhesive systems and Z-250 and TPH composite resins. Groups etched with $35 \%$ phosphoric acid solution presented bond strength values significantly higher than other acid solutions. In conclusion, the utilization of $2 \%$ boric acid solution
\end{abstract}


for etching dentin or enamel did not provide characteristics in this substrates and bond strength values similar to $35 \%$ phosphoric acid solution. 
ANEXOS 
Tabela - 7. Grupos de dentina com as respectivas áreas e valores de resistência adesiva para cada espécime

\begin{tabular}{l|c|c|c|c|c} 
& $\begin{array}{c}\text { Resistência adesiva } \\
\text { (MPa) }\end{array}$ & Área $\left(\mathbf{m m}^{2}\right)$ & & $\begin{array}{c}\text { Resistência adesiva } \\
\text { (MPa) }\end{array}$ & Área(mm \\
\hline Grupo 1 & 49 & 0,95 & Grupo 3 & 25,6 & 0,95 \\
\hline Grupo 1 & 32,9 & 0,95 & Grupo 3 & 7,1 & 0,95 \\
\hline Grupo 1 & 45,0 & 0,95 & Grupo 3 & 13,1 & 0,95 \\
\hline Grupo 1 & 42,1 & 0,95 & Grupo 3 & 18,1 & 0,95 \\
\hline Grupo 1 & 47,3 & 0,95 & Grupo 3 & 28,9 & 0,95 \\
\hline Grupo 1 & 46,5 & 0,95 & Grupo 3 & 18,6 & 0,95 \\
\hline Grupo 1 & 34,4 & 0,95 & Grupo 3 & 24,0 & 0,95 \\
\hline Grupo 1 & 32,1 & 0,95 & Grupo 3 & 15,5 & 0,95 \\
\hline Grupo 1 & 35,8 & 0,95 & Grupo 3 & 10,2 & 0,95 \\
\hline Grupo 1 & 41,2 & 0,95 & Grupo 3 & 17,9 & 0,95 \\
\hline Grupo 1 & 48,1 & 0,95 & Grupo 3 & 13,9 & 0,95 \\
\hline Grupo 1 & 35,6 & 0,95 & Grupo 3 & 13,6 & 0,95 \\
\hline Grupo 1 & 39,9 & 0,95 & Grupo 3 & 12,3 & 0,95 \\
\hline Grupo 1 & 49,7 & 0,95 & Grupo 3 & 11,6 & 0,95 \\
\hline Grupo 1 & 53,2 & 0,95 & Grupo 4 & 3,0 & 0,95 \\
\hline Grupo 1 & 36,2 & 0,95 & Grupo 4 & 2,1 & 0,95 \\
\hline Grupo 1 & 36,5 & 0,95 & Grupo 4 & 8,1 & 0,95 \\
\hline Grupo 1 & 46,2 & 0,95 & Grupo 4 & 8,7 & 0,95 \\
\hline Grupo 1 & 41,8 & 0,95 & Grupo 4 & 3,4 & 0,95 \\
\hline Grupo 1 & 44,1 & 0,95 & Grupo 4 & 6,3 & 0,95 \\
\hline Grupo 2 & 25,1 & 0,95 & Grupo 4 & 6,9 & 0,95 \\
\hline Grupo 2 & 20,9 & 0,95 & Grupo 4 & 6,0 & 0,95 \\
\hline Grupo 2 & 15,7 & 0,95 & Grupo 4 & 8,7 & 0,95 \\
\hline Grupo 2 & 14,0 & 0,95 & Grupo 4 & 8,2 & 0,95 \\
\hline Grupo 2 & 17,7 & 0,95 & Grupo 4 & 3,9 & 0,95 \\
\hline Grupo 2 & 5,0 & 0,95 & Grupo 5 & 10,4 & 0,95 \\
\hline Grupo 2 & 6,3 & 0,95 & Grupo 5 & 15,1 & 0,95 \\
\hline Grupo 2 & 8,1 & 0,95 & Grupo 5 & 12,6 & 0,95 \\
\hline Grupo 2 & 17,5 & 0,95 & Grupo 5 & 7,2 & 0,95 \\
\hline Grupo 2 & 22,1 & 0,95 & Grupo 5 & 7,5 & 0,95 \\
\hline Grupo 2 & 8,3 & 0,95 & Grupo 5 & 22,2 & 0,95 \\
\hline Grupo 2 & 11,4 & 0,95 & Grupo 5 & 8,0 & 0,95 \\
\hline Grupo 2 & 25,8 & 0,95 & Grupo 5 & 9,9 & 0,95 \\
\hline Grupo 2 & 10,4 & 0,95 & Grupo 5 & 5,1 & 0,95 \\
\hline Grupo 2 & 17,5 & 0,95 & Grupo 5 & 9,4 & 0,95 \\
\hline Grupo 3 & 6,2 & 0,95 & Grupo 5 & 9,8 & 0,95 \\
\hline Grupo 3 & 16,0 & 0,95 & Grupo 5 & 14,0 & 0,95 \\
\hline Grupo 3 & 18,2 & 0,95 & Grupo 5 & 8,6 & 0,95 \\
\hline Grupo 3 & 26,7 & 0,95 & Grupo 5 & 8,5 & 0,95 \\
\hline Grupo 3 & 8,5 & 0,95 & & & \\
\hline & & & & & \\
\hline
\end{tabular}




\begin{tabular}{|c|c|c|c|c|c|}
\hline & $\begin{array}{c}\text { Resistência } \\
\text { adesiva (MPa) }\end{array}$ & Área $\left(\mathrm{mm}^{2}\right)$ & & $\begin{array}{c}\text { Resistência } \\
\text { adesiva(MPa) }\end{array}$ & Área $\left(\mathrm{mm}^{2}\right)$ \\
\hline Grupo 6 & 35,8 & 0,96 & Grupo 8 & 11,3 & 1,02 \\
\hline Grupo 6 & 36,4 & 0,80 & Grupo 8 & 27,0 & 0,83 \\
\hline Grupo 6 & 36 & 1,02 & Grupo 8 & 13,3 & 0,86 \\
\hline Grupo 6 & 29,1 & 0,90 & Grupo 8 & 22,9 & 0,87 \\
\hline Grupo 6 & 28,7 & 0,92 & Grupo 8 & 16,3 & 0,94 \\
\hline Grupo 6 & 35,6 & 0,83 & Grupo 8 & 43,5 & 0,81 \\
\hline Grupo 6 & 35,8 & 0,91 & Grupo 8 & 26,1 & 0,86 \\
\hline Grupo 6 & 28,1 & 1,00 & Grupo 8 & 11,8 & 0,82 \\
\hline Grupo 6 & 35,1 & 1,02 & Grupo 9 & 30,0 & 0,81 \\
\hline Grupo 6 & 32,1 & 0,89 & Grupo 9 & 33 & 0,81 \\
\hline Grupo 6 & 23,9 & 0,97 & Grupo 9 & 19,5 & 1,09 \\
\hline Grupo 6 & 50,6 & 0,82 & Grupo 9 & 18,0 & 1,01 \\
\hline Grupo 6 & 53,8 & 0,87 & Grupo 9 & 17,1 & 0,94 \\
\hline Grupo 6 & 30,7 & 0,88 & Grupo 9 & 26,9 & 0,90 \\
\hline Grupo 6 & 28,4 & 0,81 & Grupo 9 & 17,5 & 0,96 \\
\hline Grupo 6 & 18,4 & 1,08 & Grupo 9 & 34,9 & 0,76 \\
\hline Grupo 6 & 25,8 & 0,92 & Grupo 9 & 32,1 & 0,72 \\
\hline Grupo 6 & 33,5 & 1,00 & Grupo 9 & 21,7 & 0,96 \\
\hline Grupo 6 & 24,4 & 0,82 & Grupo 9 & 27 & 0,77 \\
\hline Grupo 7 & 34,8 & 1,03 & Grupo 9 & 24,9 & 0,84 \\
\hline Grupo 7 & 36,3 & 0,82 & Grupo 9 & 19,5 & 0,93 \\
\hline Grupo 7 & 36,3 & 0,74 & Grupo 9 & 32,5 & 0,82 \\
\hline Grupo 7 & 12,1 & 0,81 & Grupo 9 & 20,2 & 0,69 \\
\hline Grupo 7 & 35,1 & 0,72 & Grupo 10 & 18,8 & 1,00 \\
\hline Grupo 7 & 21,2 & 1,00 & Grupo 10 & 24,7 & 0,94 \\
\hline Grupo 7 & 7,8 & 1,06 & Grupo 10 & 17,4 & 1,05 \\
\hline Grupo 7 & 27 & 0,85 & Grupo 10 & 13,7 & 0,96 \\
\hline Grupo 7 & 23,6 & 0,73 & Grupo 10 & 15,3 & 0,89 \\
\hline Grupo 7 & 45,1 & 0,89 & Grupo 10 & 35,8 & 1,02 \\
\hline Grupo 7 & 25,6 & 0,95 & Grupo 10 & 19,7 & 0,90 \\
\hline Grupo 7 & 40,3 & 0,84 & Grupo 10 & 13,5 & 1,08 \\
\hline Grupo 7 & 27,1 & 1,21 & Grupo 10 & 45,7 & 0,95 \\
\hline Grupo 7 & 43,5 & 0,81 & Grupo 10 & 21,9 & 0,75 \\
\hline Grupo 7 & 27,1 & 0,80 & Grupo 10 & 31,3 & 0,92 \\
\hline Grupo 8 & 20,4 & 0,90 & Grupo 10 & 33,7 & 0,91 \\
\hline Grupo 8 & 36,2 & 0,92 & Grupo 10 & 23,3 & 0,94 \\
\hline Grupo 8 & 44,1 & 0,90 & Grupo 10 & 41 & 0,80 \\
\hline Grupo 8 & 53,2 & 1,09 & Grupo 10 & 31 & 0,82 \\
\hline Grupo 8 & 31,3 & 1,09 & Grupo 10 & 19,7 & 0,87 \\
\hline Grupo 8 & 29,7 & 1,01 & Grupo 10 & 20,9 & 0,78 \\
\hline Grupo 8 & 47,4 & 0,88 & Grupo 10 & 24,5 & 1,04 \\
\hline Grupo 8 & 38,8 & 0,93 & Grupo 10 & 22,8 & 0,96 \\
\hline Grupo 8 & 39,0 & 1,01 & Grupo 10 & 29,9 & 0,88 \\
\hline Grupo 8 & 14,9 & 1,02 & & & \\
\hline Grupo 8 & 16,8 & 0,98 & & & \\
\hline
\end{tabular}


Tabela -8 . Grupos de esmalte com as respectivas áreas e valores de resistência adesiva para cada espécime

\begin{tabular}{|c|c|c|c|c|c|}
\hline & $\begin{array}{c}\text { Resistência } \\
\text { adesiva (MPa) }\end{array}$ & Área $\left(\mathrm{mm}^{2}\right)$ & & $\begin{array}{c}\text { Resistência } \\
\text { adesiva (MPa) }\end{array}$ & Área $\left(\mathrm{mm}^{2}\right)$ \\
\hline Grupo 1 & 48,3 & 0,86 & Grupo 3 & 10,3 & 0,83 \\
\hline Grupo 1 & 58,9 & 1,00 & Grupo 3 & 9,8 & 0,87 \\
\hline Grupo 1 & 35 & 0,77 & Grupo 3 & 12,3 & 0,82 \\
\hline Grupo 1 & 40 & 0,76 & Grupo 3 & 6,2 & 0,89 \\
\hline Grupo 1 & 38,4 & 0,96 & Grupo 3 & 10,9 & 0,92 \\
\hline Grupo 1 & 38,6 & 0,78 & Grupo 3 & 14,4 & 0,92 \\
\hline Grupo 1 & 21,7 & 0,89 & Grupo 3 & 6,1 & 0,85 \\
\hline Grupo 1 & 35,8 & 0,73 & Grupo 3 & 9,9 & 0,80 \\
\hline Grupo 1 & 47,4 & 0,85 & Grupo 3 & 11,4 & 0,73 \\
\hline Grupo 1 & 40,7 & 0,77 & Grupo 4 & 12,7 & 1,06 \\
\hline Grupo 1 & 22,1 & 0,90 & Grupo 4 & 11,5 & 0,86 \\
\hline Grupo 1 & 23,5 & 0,83 & Grupo 4 & 10,1 & 0,94 \\
\hline Grupo 1 & 47,7 & 0,65 & Grupo 4 & 4,8 & 0,70 \\
\hline Grupo 1 & 22,8 & 0,75 & Grupo 4 & 11,6 & 0,86 \\
\hline Grupo 1 & 26,5 & 0,88 & Grupo 4 & 13,7 & 0,80 \\
\hline Grupo 1 & 32,4 & 0,75 & Grupo 4 & 5,7 & 0,90 \\
\hline Grupo 1 & 47,9 & 0,74 & Grupo 4 & 3,7 & 1,01 \\
\hline Grupo 2 & 13 & 0,87 & Grupo 4 & 11,8 & 0,84 \\
\hline Grupo 2 & 11 & 0,85 & Grupo 4 & 13,5 & 0,80 \\
\hline Grupo 2 & 10,9 & 0,85 & Grupo 4 & 7,9 & 0,92 \\
\hline Grupo 2 & 11,5 & 0,96 & Grupo 4 & 8,8 & 0,99 \\
\hline Grupo 2 & 10,5 & 0,78 & Grupo 4 & 6,6 & 0,90 \\
\hline Grupo 2 & 10,8 & 0,73 & Grupo 4 & 11,6 & 0,79 \\
\hline Grupo 2 & 8,7 & 0,88 & Grupo 4 & 16,2 & 0,87 \\
\hline Grupo 2 & 6,6 & 0,94 & Grupo 4 & 10,8 & 0,82 \\
\hline Grupo 2 & 8,7 & 0,89 & Grupo 5 & 11,8 & 0,74 \\
\hline Grupo 2 & 16,7 & 0,87 & Grupo 5 & 17,6 & 0,86 \\
\hline Grupo 2 & 13,9 & 0,95 & Grupo 5 & 13,8 & 0,98 \\
\hline Grupo 2 & 8,5 & 0,94 & Grupo 5 & 13 & 0,76 \\
\hline Grupo 2 & 11,9 & 0,98 & Grupo 5 & 12,8 & 0,88 \\
\hline Grupo 2 & 14,6 & 0,94 & Grupo 5 & 13,1 & 0,90 \\
\hline Grupo 2 & 8,6 & 0,87 & Grupo 5 & 7,7 & 0,92 \\
\hline Grupo 2 & 15,0 & 0,73 & Grupo 5 & 12,8 & 0,86 \\
\hline Grupo 2 & 15,0 & 0,91 & Grupo 5 & 14 & 0,99 \\
\hline Grupo 3 & 7,3 & 0,78 & Grupo 5 & 18,3 & 0,88 \\
\hline Grupo 3 & 8,8 & 0,83 & Grupo 5 & 12,8 & 0,88 \\
\hline Grupo 3 & 17,6 & 0,79 & Grupo 5 & 8,5 & 0,91 \\
\hline Grupo 3 & 13,2 & 0,72 & Grupo 5 & 13,3 & 0,96 \\
\hline Grupo 3 & 11,3 & 0,76 & Grupo 5 & 12,7 & 0,88 \\
\hline Grupo 3 & 9,1 & 0,77 & Grupo 5 & 14,5 & 0,91 \\
\hline Grupo 3 & 13,9 & 0,93 & & & \\
\hline Grupo 3 & 16,8 & 0,78 & & & \\
\hline Grupo 3 & 12,8 & 0,85 & & & \\
\hline
\end{tabular}




\begin{tabular}{|c|c|c|c|c|c|}
\hline & $\begin{array}{c}\text { Resistência } \\
\text { adesiva (MPa) }\end{array}$ & Área $\left(\mathrm{mm}^{2}\right)$ & & $\begin{array}{c}\text { Resistência } \\
\text { adesiva( MPa) }\end{array}$ & Área $\left(\mathrm{mm}^{2}\right)$ \\
\hline Grupo 6 & 37,9 & 0,89 & Grupo 8 & 14,3 & 1,06 \\
\hline Grupo 6 & 40,8 & 0,68 & Grupo 8 & 13,7 & 0,78 \\
\hline Grupo 6 & 45,4 & 0,84 & Grupo 8 & 17,9 & 0,72 \\
\hline Grupo 6 & 45,8 & 0,80 & Grupo 8 & 8,7 & 0,80 \\
\hline Grupo 6 & 47,8 & 0,82 & Grupo 8 & 14 & 0,83 \\
\hline Grupo 6 & 42,8 & 0,73 & Grupo 8 & 10,7 & 0,85 \\
\hline Grupo 6 & 49,1 & 0,87 & Grupo 8 & 15,8 & 0,93 \\
\hline Grupo 6 & 45,4 & 0,82 & Grupo 8 & 17,9 & 0,78 \\
\hline Grupo 6 & 42,7 & 0,86 & Grupo 8 & 14 & 0,70 \\
\hline Grupo 6 & 32,6 & 0,79 & Grupo 8 & 14,5 & 0,86 \\
\hline Grupo 6 & 38,9 & 0,80 & Grupo 8 & 13,7 & 0,90 \\
\hline Grupo 6 & 37,8 & 0,99 & Grupo 9 & 6,7 & 0,88 \\
\hline Grupo 6 & 42,9 & 0,65 & Grupo 9 & 11,3 & 0,88 \\
\hline Grupo 6 & 33,5 & 0,80 & Grupo 9 & 15,3 & 0,88 \\
\hline Grupo 6 & 44,5 & 0,83 & Grupo 9 & 13,9 & 0,98 \\
\hline Grupo 6 & 51,1 & 0,76 & Grupo 9 & 6,1 & 0,80 \\
\hline Grupo 6 & 45,8 & 0,90 & Grupo 9 & 11,2 & 0,80 \\
\hline Grupo 6 & 49,2 & 0,78 & Grupo 9 & 11,4 & 0,98 \\
\hline Grupo 6 & 34,7 & 0,72 & Grupo 9 & 10,6 & 0,94 \\
\hline Grupo 6 & 37,5 & 0,74 & Grupo 9 & 10,7 & 0,84 \\
\hline Grupo 7 & 16,1 & 0,80 & Grupo 9 & 13,9 & 0,90 \\
\hline Grupo 7 & 14,8 & 0,86 & Grupo 9 & 15 & 0,75 \\
\hline Grupo 7 & 12 & 0,80 & Grupo 9 & 13,7 & 0,93 \\
\hline Grupo 7 & 18,2 & 0,92 & Grupo 9 & 19,8 & 1,06 \\
\hline Grupo 7 & 13,3 & 0,82 & Grupo 9 & 17,1 & 0,70 \\
\hline Grupo 7 & 9,1 & 0,69 & Grupo 9 & 8 & 0,91 \\
\hline Grupo 7 & 6,4 & 1,06 & Grupo 9 & 8,9 & 0,76 \\
\hline Grupo 7 & 11,4 & 0,99 & Grupo 9 & 12,1 & 0,78 \\
\hline Grupo 7 & 14,6 & 0,95 & Grupo 9 & 19,2 & 0,80 \\
\hline Grupo 7 & 12,2 & 0,83 & Grupo 9 & 21,1 & 1,06 \\
\hline Grupo 7 & 23,2 & 0,93 & Grupo 9 & 15,9 & 0,94 \\
\hline Grupo 7 & 9,6 & 0,94 & Grupo 9 & 11,2 & 0,81 \\
\hline Grupo 7 & 13 & 0,85 & Grupo 9 & 16,5 & 0,79 \\
\hline Grupo 7 & 22,6 & 0,91 & Grupo 10 & 24,4 & 0,77 \\
\hline Grupo 7 & 9,8 & 1,00 & Grupo 10 & 22,5 & 0,87 \\
\hline Grupo 7 & 9,5 & 0,79 & Grupo 10 & 12,1 & 0,87 \\
\hline Grupo 7 & 20,4 & 0,85 & Grupo 10 & 10,8 & 0,91 \\
\hline Grupo 7 & 13,6 & 0,77 & Grupo 10 & 14,1 & 0,91 \\
\hline Grupo 7 & 7,1 & 0,80 & Grupo 10 & 23,7 & 1,00 \\
\hline Grupo 8 & 13,9 & 0,92 & Grupo 10 & 16,8 & 0,86 \\
\hline Grupo 8 & 16,9 & 0,80 & Grupo 10 & 13,1 & 0,76 \\
\hline Grupo 8 & 17,3 & 0,77 & Grupo 10 & 17,5 & 1,00 \\
\hline Grupo 8 & 13,6 & 0,76 & Grupo 10 & 21,6 & 0,90 \\
\hline Grupo 8 & 11,3 & 0,95 & Grupo 10 & 14,3 & 0,84 \\
\hline Grupo 8 & 12,3 & 0,88 & Grupo 10 & 14,9 & 0,81 \\
\hline Grupo 8 & 12,4 & 0,79 & Grupo 10 & 15,7 & 0,89 \\
\hline Grupo 8 & 10,3 & 0,89 & Grupo 10 & 18,2 & 0,91 \\
\hline Grupo 8 & 16,6 & 0,72 & Grupo 10 & 17,1 & 0,80 \\
\hline Grupo 8 & 12,9 & 0,86 & Grupo 10 & 19,3 & 0,75 \\
\hline Grupo 8 & 10,4 & 0,80 & Grupo 10 & 12,3 & 0,88 \\
\hline Grupo 8 & 7,2 & 0,87 & Grupo 10 & 24,9 & 0,88 \\
\hline
\end{tabular}




\section{FACULDADE DE ODONTOLOGIA DE BAURU COMTTÊ DE ÉTICA EM P Ṕ ESQUISA}

Bauru, 27 de abril de 2001

Ilmo. Sr.

Prof. Dr. José Carlos Petreira

FOB USP

Senhor Professor.

O projeto de pesquisa denominado "Estudo do ácido bórico a $2 \%$ como opção para o condicionamento da dentina e do esmalte - Avaliação da resistência adesiva e dó padrão de condicionamento em MEV' de autoria do C.D. Leonardo Cesar Costa e que será desenvolvido sob sua orientação, foi recebido por este Comites e encaminhado no relator para avaliaçao quanto aos seus aspectos éticos.

O parecer do relator, aprovando o projeto, foi aceito pelo Comite de Ética em Pesquisa desta Faculdade na reuniåo do dia 26 de abril de 2001.

Atenciosamente

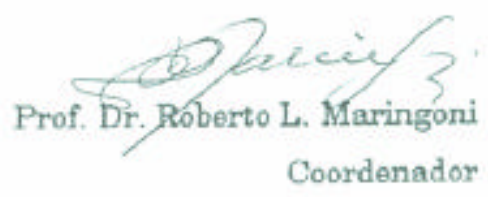




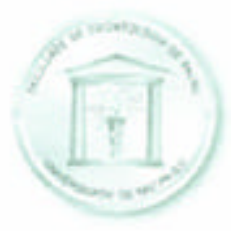

O. $n^{\circ}$ CEP 21 2003FOB

Bauru, 13 de maio de 2003

\section{Universidade de São Paulo Faculdade de Odontologia de Bauru \\ Al. Dr. Octávio Pinheiro Brisolla, 9-75 - Bauru-SP - CEP $17012-901$ - C.P. 73 PABX (0XX14)235-8000 - FAX (0XX14)223-4679 \\ Comille de Ética em Pesquisa}

Senhor Protessor,

Informamos que após análise por este Comitê de Ética em Pesquisa em Seres Humanos, seu pedido de alteracazo do título do projeto de pesquisa intitulado 'Estudo do ácido bórico a $2 \%$ como opção para $\odot$ condicionamento da dentina e do esmalte. Avaliaçăo da resistência adesiva e do padrāo de condicionamento em MEV' de autoria do CD. Leonardo César Costa, sob a sua orientaçâo, para "Avaliaçăo da resistència adesiva à dentina e ao esmalte e do padrão de condicionamento após a aplicação do ácido bórico a $2 \%$, fol aprovado considerando que sua molodologia nào sotreu modificaçes. realizada no dia 26 de abril de 2001

Informamos, ainda, que referido projelo de pesquisa teve sua aprovaçåo em reuniāo

Lembramos que após o envio do trabalho concluido, este Comité enviará o parecer final, que sera utilizado para a publicaçào do trabaho.

Alenciosamente,

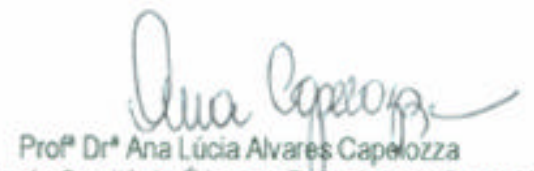

Coordenadora do Comitê de Etica em Pelquisa em Seres Humanos

$\| m^{0}$ Sr. Prof. Dr. José Carlos Pereira

DD. Docente do Departamento de Dentistica, Endodontia e Materiais Dentários 


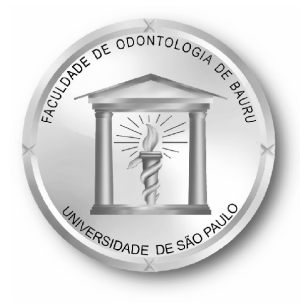

\section{Universidade de São Paulo \\ Faculdade de Odontologia de Bauru}

Al. Dr. Octávio Pinheiro Brisolla, 9-75 - Bauru-SP - CEP

17012-901 - C.P. 73

PABX (0XX14)235-8000 - FAX (0XX14)223-4679

Departamento de Dentística, Endodontia e

Materiais Dentários

e-mail : dep-demd @ fob.usp.br -Fone: (0XX14) 235-8266

\section{TERMO DE CONSENTIMENTO LIVRE E ESCLARECIDO}

Pelo presente termo que atende às exigências legais e, o Sr. (a)

portador da cédula de identidade _, após leitura minuciosa da CARTA DE INFORMAÇÃO AO PACIENTE, devidamente explicada pelos profissionais em seus mínimos detalhes, ciente dos serviços e procedimentos aos quais será submetido, não restando quaisquer dúvidas a respeito do lido e explicado, firma seu CONSENTIMENTO LIVRE E ESCLARECIDO concordando em participar da pesquisa proposta.

Fica claro que o paciente ou seu representante legal pode a qualquer momento retirar seu CONSENTIMENTO LIVRE E ESCLARECIDO e deixar de participar desta pesquisa e ciente de que todas as informações prestadas tornaram-se confidenciais e guardadas por força de sigilo profissional (Art. $9^{\circ}$ do Código de Ética Odontológica).

Por estarem de acordo assinam o presente termo.

Bauru-SP, de de 


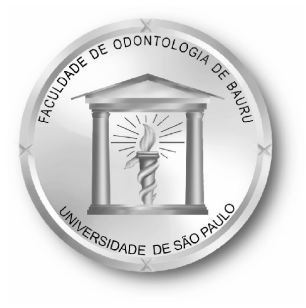

\section{Universidade de São Paulo \\ Faculdade de Odontologia de Bauru}

Al. Dr. Octávio Pinheiro Brisolla, 9-75 - Bauru-SP - CEP

17012-901 - C.P. 73

PABX (0XX14)235-8000 - FAX (0XX14)223-4679

Departamento de Dentística, Endodontia e Materiais

Dentários

e-mail : dep-demd@ fob.usp.br -Fone: (0XX14) 235-8266

\section{$\underline{\text { TERMO }} \underline{\text { DE }} \underline{\text { CONSENTIMENTO LIVRE E ESCLARECIDO }}$}

(a)

Pelo presente termo que atende às exigências legais e éticas, o $\mathrm{Sr}$. cédula de identidade $\mathrm{RG} \mathrm{n}^{\mathrm{O}}$, após leitura minuciosa da CARTA DE INFORMAÇÃO AO PACIENTE, a qual foi devidamente explicada pelos profissionais, que o atenderam em seus mínimos detalhes. Está ciente dos procedimentos (tratamentos) que será submetido e não restando quaisquer dúvidas a respeito do lido e explicado, autoriza de seu LIVRE E ESCLARECIDO CONSENTIMENTO, a doação dos dentes a serem extraídos ou dos dentes extraídos do (a) paciente que é representante legal ( em caso de menores de idade ) por indicação ortodôntica e /ou periodontal à Faculdade de Odontologia de Bauru da Universidade de São Paulo. Os dentes extraídos serão utilizados em pesquisas da Faculdade.

Fica claro que o paciente ou seu representante legal, pode a qualquer momento retirar seu CONSENTIMENTO LIVRE E ESCLARECIDO e deixar de participar destas pesquisas e ciente de que todas as informações prestadas tornaram-se confidenciais e guardadas por força de sigilo profissional (Art. $9^{\circ}$ do Código de Ética Odontológica).

Por estarem de acordo assina o presente termo.

Bauru, de de 


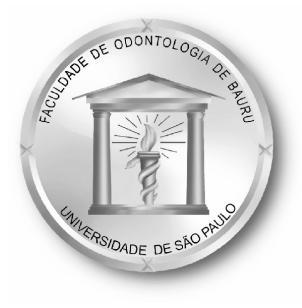

\author{
Universidade de São Paulo \\ Faculdade de Odontologia de Bauru \\ Al. Dr. Octávio Pinheiro Brisolla, 9-75 - Bauru-SP - CEP \\ 17012-901 - C.P. 73 \\ PABX (0XX14)235-8000 - FAX (0XX14)223-4679 \\ Departamento de Dentística, Endodontia e Materiais \\ Dentários \\ $\boldsymbol{e}$-mail : dep-demd@ fob.usp.br -Fone: (0XX14) 235-8266
}

Declaração de critérios para suspensão ou encerramento da pesquisa

Título do Trabalho : “Estudo do ácido bórico a 2\% como opção para o condicionamento da dentina e do esmalte - Avaliação da resistência adesiva e do padrão de condicionamento em MEV"

Autores : Orientador: Prof ${ }^{\circ}$. Dr ${ }^{\mathrm{O}}$ José Carlos Pereira

Mestrando : Leonardo César Costa

\title{
Critérios para Suspensão ou Encerramento da Pesquisa
}

Os critérios para suspensão da pesquisa são de ordem operacionais. Como os que inviabilizam a constituição da amostra a ser estudada. Ou outros que podem surgir no transcorrer do trabalho. O grau de interferência negativa no trabalho será avaliado. Caso não possam ser corrigidos discutir-se-á o redelineamento do projeto ou mesmo sua suspensão temporária ou definitiva.

Bauru, 28 de Março de 2001. 


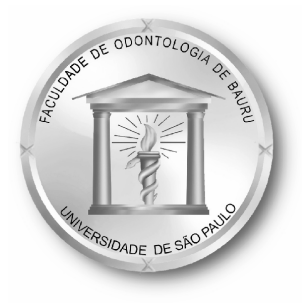

\author{
Universidade de São Paulo \\ Faculdade de Odontologia de Bauru \\ Al. Dr. Octávio Pinheiro Brisolla, 9-75 - Bauru-SP - CEP \\ 17012-901 - C.P. 73 \\ PABX (0XX14)235-8000 - FAX (0XX14)223-4679 \\ Departamento de Dentística, Endodontia e Materiais \\ Dentários \\ e-mail : dep-demd@ fob.usp.br -Fone: (0XX14) 235-8266
}

Declaração de análise dos riscos e benefícios

Título do Trabalho : “Estudo do ácido bórico a 2\% como opção para o condicionamento da dentina e do esmalte - Avaliação da resistência adesiva e do padrão de condicionamento em MEV"

Autores: Orientador: Prof ${ }^{\circ}$. Dr ${ }^{0}$. José Carlos Pereira

Mestrando : Leonardo César Costa

A tendência da odontologia adesiva é buscar soluções ácidas cada vez menos agressivas que causem o menor dano possível ao complexo dentino-pulpar e ao mesmo tempo, sistemas adesivos que nos forneçam uma maior resistência adesiva possível. Assim , analisaremos a ação do ácido bórico a $2 \%$ no esmalte e na dentina e a resistência adesiva de sistemas adesivos às estruturas assim condicionadas. Os riscos contidos no presente trabalho, são inerentes aos projetos deste tipo. Uma vez realizados a partir das normas preconizadas pela Comissão Nacional de Ética em Pesquisas em Seres Humanos, obedecendo às normas de biossegurança e guardando o sigilo ético, pode-se afirmar que os riscos são estatisticamente nulos.

Bauru, 28 de Março de 2001. 


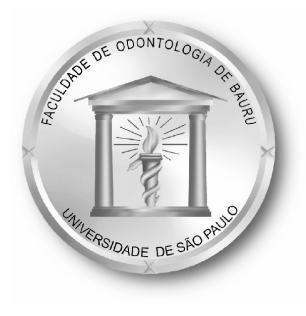

\author{
Universidade de São Paulo \\ Faculdade de Odontologia de Bauru \\ Al. Dr. Octávio Pinheiro Brisolla, 9-75 - Bauru-SP - CEP \\ $17012-901-$ C.P. 73 \\ PABX (0XX14)235-8000 - FAX (0XX14)223-4679 \\ Departamento de Dentística, Endodontia e Materiais \\ Dentários \\ e-mail : dep-demd@fob.usp.br -Fone: (0XX14) 235-8266
}

Título do Trabalho : “ Estudo do ácido bórico a $2 \%$ como opção para o condicionamento da dentina e do esmalte - Avaliação da resistência adesiva e do padrão de condicionamento em MEV"

Autores : Orientador: Prof ${ }^{\circledR}$ Dr ${ }^{\circ}$. José Carlos Pereira

Mestrando : Leonardo César Costa

TERMO DE COMPROMISSO EM CUMPRIR OS TERMOS DA RESOLUCCÃO

\title{
196/96 DO CONSELHO NACIONAL DE SAÚDE
}

Comprometemo-nos, como orientador, Prof $^{0^{~}}$ Dr ${ }^{\circ}$. José Carlos Pereira e orientado Leonardo César Costa responsável pelo projeto de pesquisa, “Estudo do ácido bórico a $2 \%$ como opção para o condicionamento da dentina e do esmalteAvaliação da resistência adesiva e do padrão de condicionamento em MEV", a fazer cumprir os termos da Resolução 196/96 do Conselho Nacional de Saúde.

Bauru, 28 de Março de 2001. 


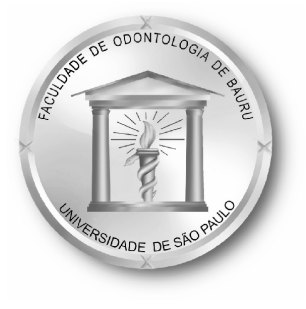

\author{
Universidade de São Paulo \\ Faculdade de Odontologia de Bauru \\ Al. Dr. Octávio Pinheiro Brisolla, 9-75 - Bauru-SP - CEP \\ 17012-901 - C.P. 73 \\ PABX (0XX14)235-8000 - FAX (0XX14)223-4679 \\ Departamento de Dentística, Endodontia e Materiais \\ Dentários \\ $\boldsymbol{e}$-mail : dep-demd@ fob.usp.br -Fone: (0XX14) 235-8266
}

Título do Trabalho : “ Estudo do ácido bórico a 2\% como opção para o condicionamento da dentina e do esmalte - Avaliação da resistência adesiva e do padrão de condicionamento em $\mathrm{MEV}$ ”

Autores : Orientador : Prof ${ }^{\mathrm{D}}$. Dr ${ }^{\circ}$. José Carlos Pereira

Mestrando : Leonardo César Costa

\title{
DECLARAČ̃̃O DE CONSENTIMENTO PARA UTILIZAĊ̃̃O DE ESPACYO FÍSICO
}

Declaro, como requisito solicitado pelo Comitê de Ética em Pesquisa da Faculdade de Odontologia de Bauru, Universidade de São Paulo, que o Departamento de Dentística, Endodontia e Materiais Dentários, compromete-se a ceder o espaço físico necessário à realização do projeto de pesquisa “Estudo do ácido bórico como opção para o condicionamento da dentina e do esmalte - Avaliação da resistência adesiva e do padrão de condicionamento em $M E V^{\prime}$ de autoria de Leonardo César Costa e sob a orientação do Prof ${ }^{\mathbf{0}}$. Dr ${ }^{\mathbf{0}}$. José Carlos Pereira.

Bauru, 28 de Março de 2001.

Prof Dra Maria Fidela de Lima Navarro Chefe do Departamento de

Dentística, Endodontia e Materiais Dentários FOB/USP. 


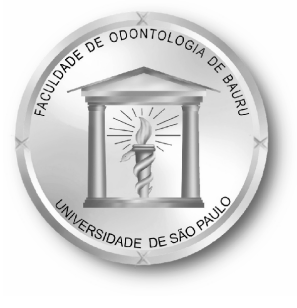

\author{
Universidade de São Paulo \\ Faculdade de Odontologia de Bauru \\ Al. Dr. Octávio Pinheiro Brisolla, 9-75 - Bauru-SP - CEP \\ 17012-901 - C.P. 73 \\ PABX (0XX14)235-8000 - FAX (0XX14)223-4679 \\ Departamento de Dentística, Endodontia e Materiais \\ Dentários

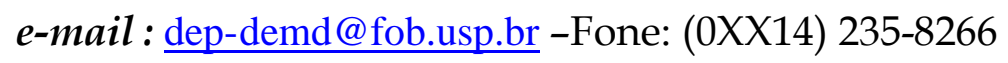

Título do Trabalho : “Estudo do ácido bórico como opção para o condicionamento da dentina e do esmalte - Avaliação da resistência adesiva e do padrão de condicionamento em MEV"

Autores : Orientadora: Prof ${ }^{\oplus}$. Dr $^{\circ}$. José Carlos Pereira

Mestrando : Leonardo César Costa

\title{
Declaracão para divulgacão de resultados
}

Declaramos, como requisito solicitado pelo Comitê de Ética em Pesquisa da Faculdade de Odontologia de Bauru, Universidade de São Paulo, que todos os resultados do projeto de pesquisa “Estudo do ácido bórico como opção para o condicionamento da dentina e do esmalte - Avaliação da resistência adesiva e do padrão de

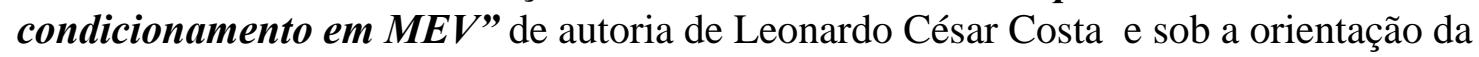
Prof $^{\circ}$. Dr ${ }^{0}$. José Carlos Pereira, serão publicados independentemente, de serem

favoráveis ou desfavoráveis, não existindo cláusulas restritivas quanto à divulgação dos mesmos.

Bauru, 28 de Março de 2001.

\section{Prof $^{0}$ Dr $^{0}$ José Carlos Pereira \\ Orientador \\ Leonardo César Costa}

Autor 